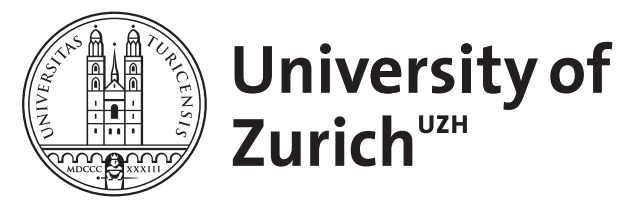

\title{
Mature Modifications and Sexual Dimorphism
}

\author{
Klug, Christian ; Zatoń, Michał ; Parent, Horacio ; Hostettler, Bernhard ; Tajika, Amane
}

\begin{abstract}
Allometric growth between different parts of the shell often hampers the identification of mollusk shells, particularly in such cases where preadult shell growth varies strongly. Especially in gastropods, the terminal aperture is often less variable and yields morphological information essential for species determination (e.g. Vermeij 1993; Urdy et al. 2010a, b). In fossil mollusk shells, the adult aperture (peristome)is often missing, partially due to an early death, and partially due to destructive processes, which occurred post mortem (taphonomy). Therefore, the entire shell ontogeny is known only from a small fraction of all ammonoid taxa (e.g., Landman et al. 2012). Nevertheless, knowledge of the adult shell of ammonoids is very important since it can yield morphological information essential for systematics and for the reconstruction of various aspects of their paleobiology.
\end{abstract}

DOI: https://doi.org/10.1007/978-94-017-9630-9_7

Posted at the Zurich Open Repository and Archive, University of Zurich ZORA URL: https://doi.org/10.5167/uzh-121708

Book Section

Originally published at:

Klug, Christian; Zatoń, Michał; Parent, Horacio; Hostettler, Bernhard; Tajika, Amane (2015). Mature Modifications and Sexual Dimorphism. In: Klug, Christian. Topics in Geobiology. Heidelberg New York London: Springer, 253-320.

DOI: https://doi.org/10.1007/978-94-017-9630-9_7 


\title{
Chapter 7 \\ Mature Modifications and Sexual Dimorphism
}

\author{
Christian Klug, Michał Zatoń, Horacio Parent, Bernhard Hostettler and \\ Amane Tajika
}

\subsection{Introduction}

Allometric growth between different parts of the shell often hampers the identification of mollusk shells, particularly in such cases where preadult shell growth varies strongly. Especially in gastropods, the terminal aperture is often less variable and yields morphological information essential for species determination (e.g. Vermeij 1993; Urdy et al. 2010a, b). In fossil mollusk shells, the adult aperture (peristome) is often missing, partially due to an early death, and partially due to destructive processes, which occurred post mortem (taphonomy). Therefore, the entire shell ontogeny is known only from a small fraction of all ammonoid taxa (e.g., Landman et al. 2012). Nevertheless, knowledge of the adult shell of ammonoids is very important since it can yield morphological information essential for systematics and for the reconstruction of various aspects of their paleobiology.

C. Klug $(\bowtie) \cdot$ A. Tajika

Paläontologisches Institut und Museum, University of Zurich,

Karl Schmid-Strasse 6, 8006 Zurich, Switzerland

e-mail: chklug@pim.uzh.ch

A. Tajika

e-mail: amane.tajika@pim.uzh.ch

M. Zatoń

Faculty of Earth Sciences, University of Silesia,

Będzińska 60, 41-200 Sosnowiec, Poland

e-mail: mzaton@wnoz.us.edu.pl

H. Parent

Laboratorio de Paleontología, IFG-FCEIA, Universidad Nacional de Rosario,

Pellegrini 250, 2000 Rosario, Argentina

e-mail: parent@fceia.unr.edu.ar

B. Hostettler

Naturhistorisches Museum, Bernastrasse 15,

3005 Bern, Switzerland

e-mail: bernhard.hostettler@nmbe.ch

(C) Springer Science+Business Media Dordrecht 2015

C. Klug et al. (eds.), Ammonoid Paleobiology: From Anatomy to Ecology,

Topics in Geobiology 43, DOI 10.1007/978-94-017-9630-9_7 
In the past five decades, numerous researchers have worked on documenting mature modifications and it can be said that the maturity of an ammonoid shell can be determined with some confidence (e.g. Makowski 1962, 1971, 1991; Callomon 1963; Brochwicz-Lewiński \& Różak 1976; Bucher and Guex 1990; Brooks 1991; Bucher et al. 1996; Davis et al. 1996; Schweigert and Dietze 1998; Parent 1997; Klug 2004; Parent et al. 2008a; Zatoń 2008; Landman et al. 2012). The reliable identification of mature shells is the logical prerequisite to determine sexual dimorphism. Both mature modifications and sexual dimorphism are discussed in this chapter, since these are intimately linked with each other. Much of the information contained herein comes from the original work of Davis et al. (1996).

\subsection{Mature Modifications}

\subsubsection{Modifications in Recent Nautilida}

Modern Nautilida have been studied for over a century (e.g., Griffin 1900). Much of this research was summarized in Ward (1987). Therein, he listed the mature modifications that have been seen in shells of Recent nautilids (see also Collins and Ward 1987). This list was summarized by Klug (2004) and is repeated here:

1. Shell growth band (shell thickening at the apertural edge, $25 \mathrm{~mm}$ wide and up to $1 \mathrm{~mm}$ thick).

2. Black band (evenly distributed around the aperture, 1 to $5 \mathrm{~mm}$ wide).

3. Deepening of the ocular sinuses.

4. Reduction of relative whorl height by a decrease in whorl expansion rate.

5. Reduction of whorl width by a decrease in whorl width expansion rate; this is accompanied by a more rounded venter.

6. Septal thickening (the terminal septum is up to $30 \%$ thicker than the preceding ones).

7. Septal crowding.

8. Maximum shell diameter (unreliable character because of variability).

9. White ventral area.

10. Increase in body chamber length.

11. Reduction of cameral liquid (probably to compensate for the additional shell material at the aperture and the longer body chamber).

\subsubsection{Modifications in Ammonoidea}

Among the mature modifications known from nautilids listed above, the majority has also been documented from ammonoids, except the shell growth band, the septal thickness, the white venter, and the reduction of the cameral liquid. Some 
of these mature modifications that are unknown in ammonoids potentially are unknown because they are not or only poorly preserved or expressed in a different way. For example, the shell growth band could be homologized with a (sub-)terminal shell thickening (a constriction), the white venter might be unknown because of the poor knowledge of color patterns in ammonoids (Mapes and Larson 2015), and the mature reduction of cameral liquid could be tested in the future using volume models of ammonoid shells (Hoffmann et al. 2013; Tajika et al. 2014).

Some of these structures, however, may occur in similar forms in earlier growth stages, either as consequence of an injury, adverse living conditions, and illnesses, or as a recurrent growth feature such as megastriae (growth halts; Bucher and Guex 1990; Bucher et al. 1996). These similar structures may be misinterpreted, what represents a general problem that occurs in research related to mature modifications. Therefore, to ascertain the quality of any such structure as a mature modification, it is helpful to look for other modifications supporting the hypothesis of adulthood for the material under consideration. For instance, a specimen may show septal crowding, which is insufficient as an isolated character to prove adulthood. If, however, it is additionally associated with, e.g., a crowding of growth lines and a change in shell geometry, it is more likely that the given specimen had actually reached maturity.

Another difficulty is linked with the questions of sexual maturity, semelparity, and iteroparity. Is the formation of mature modifications linked with sexual maturity in ammonoids as it is in modern nautilids? Do recurrent structures such as late ontogenetic pre-terminal growth halts coincide with phases of reproduction and would thus indicate iteroparity? These questions are currently difficult to test scientifically, because the soft-part evidence needed to do it is missing. Nevertheless, it appears likely that the ammonoids were sexually mature at the time when growth had terminated and mature modifications of the shell had formed because this is the case in Recent Nautilida.

It might appear trivial, but we still want to point out that in most cases, only a couple of the criteria for maturity listed below will be fulfilled or visible in one specimen. It is also highly unlikely that all criteria will be met in a single specimen. This is due to the fact that in some species, some of these modifications were never realized and certain modes of preservation allow the recording of some characters while others are lost (e.g., Ruzhencev 1962, 1974; Davis et al. 1996).

In the following, we will briefly discuss the most important mature modifications that have become known. Naturally, this list will be incomplete, since many taxa may have formed their own unique adult shell morphology.

\subsubsection{Septal Crowding}

Septal crowding is potentially one of the most widely recognized and published mature modifications in ammonoids, which is reflected in an overwhelming number of publications in which this prominent feature is mentioned (e.g., Westermann 


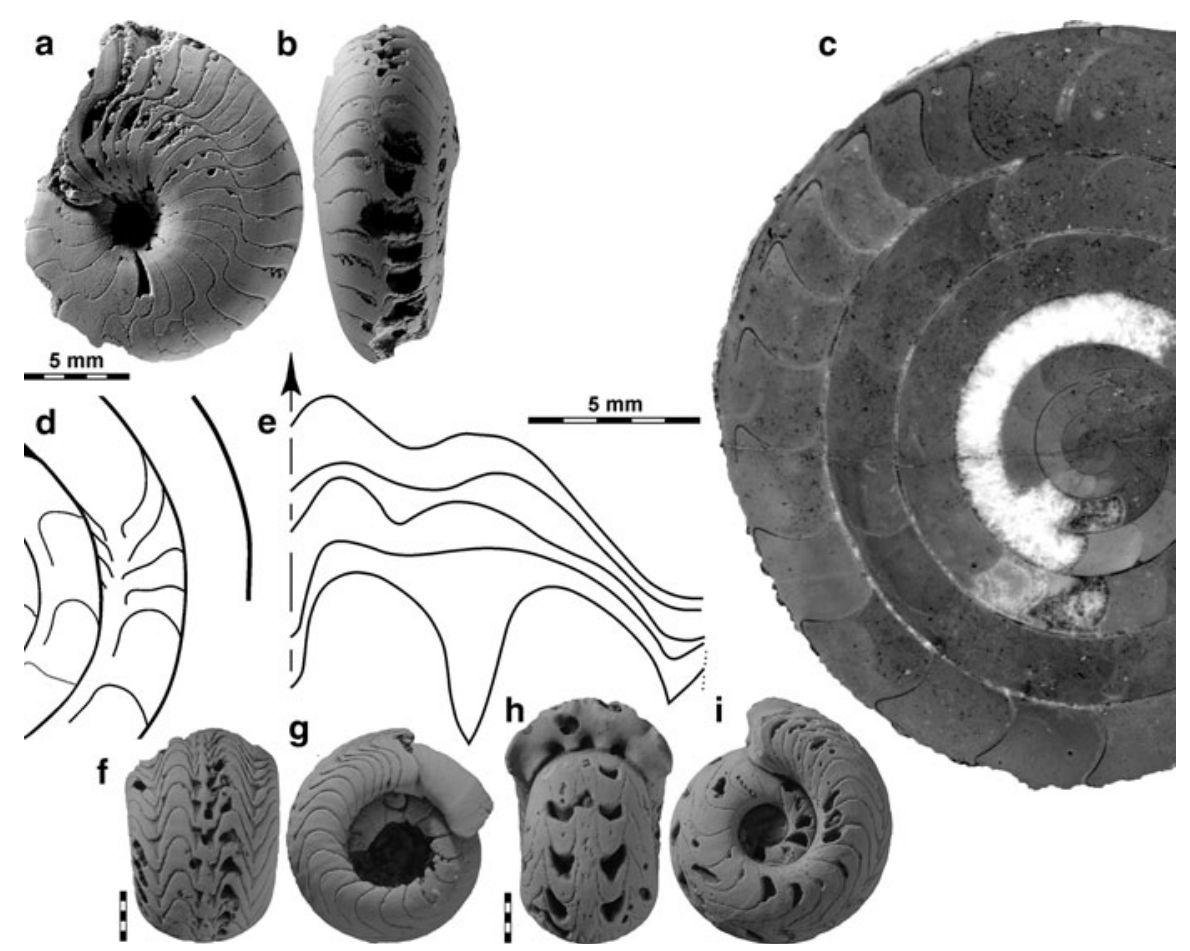

Fig. 7.1 Examples of septal crowding from the Devonian and Carboniferous. a, b Pernoceras crebriseptum, MB.C.9140.1, Milligan Canyon, Montana, US, lateral and ventral views; $\mathrm{dm} 24 \mathrm{~mm}$. c Sellanarcestes sp., PIMUZ 28586, late Emsian, Oufrane, Morocco; dm 77 mm. d, e Wocklumeria sphaeroides, adult specimen, MB.C.9306.1, Bou Tlidat, Maïder, Morocco, from Ebbighausen and Korn (2007). d Septal section, note the change in septal angle and siphuncle position. e suture lines, note the extreme simplification $(\mathrm{dm}=25 \mathrm{~mm}) . \mathbf{f}-\mathbf{i}$, Ouaoufilalites creber, S of Oued Temertasset, Algeria (from Korn et al. 2010). f, $\mathbf{g}$ ventral and lateral view of MB.C.18733.3. h, i ventral and lateral view of MB.C.18733.2

1971; Kulicki 1974; Zakharov 1977; Blind and Jordan 1979; Doguzhaeva 1982; Weitschat and Bandel 1991; Klug 2001, 2004; Ebbighausen and Korn 2007; Kraft et al. 2008). Septal crowding affects the distance of at least the last two septa (for nautilids, see, e.g., Willey 1902). This term applies to cases in which the distance between septa (best measured in angles) is reduced (Fig. 7.1). Such a reduction in septal spacing is, however, not only found in adult specimens but sometimes also in preadult ones (Korn and Titus 2006; Kraft et al. 2008 and references therein). Premature septal crowding can be caused by various factors, which can only rarely be identified. More than twenty septa might be more tightly arranged than the preceding ones (e.g., Pernoceras crebriseptum in Korn and Titus 2006), documenting a prolonged reduction of the growth rate near the termination of growth (Fig. 7.1). Nevertheless, septal crowding is a good indicator for adulthood when combined with other mature modifications. 


\subsubsection{Thickness of Septa and Sutural Complexity}

In several ammonoids, septal thickness increases towards adulthood, mainly the last adult, crowded septa (Westermann 1971, p. 15, fig. 7.8), as in modern nautilids (Collins and Ward 1987). Furnish and Knapp (1966) reported a case of simplification of the terminal suture in Paleozoic forms. Davis et al. (1996) illustrated a Texoceras from the Permian of Texas, where the last sutures were not only approximated but the last suture also displays shallower lobes, which are less parabolic than the preceding ones. An impressive example has been illustrated by Ebbighausen and Korn (2007). In their fig. 7, they show the last few septa of a Late Devonian Wocklumeria (Fig. 7.1). In this genus, the normal septum displays some deep parabolic pointed lobes. These lobes are completely reduced in the last four septa, which are very strongly approximated and also show a strong change in inclination. This reduction (Fig. 7.1) in sutural frilling might be a consequence of the reduced space between two successive septa due to the limited forward movement of the soft body, which did not produce sufficient space to create lobes of similar length as in the preceding suture. Alternatively, the smaller chamber volume might have required a lower surface to remove the lesser amount of cameral fluid from the new chamber.

\subsubsection{Change in Coiling and Whorl Cross Section}

Many Paleozoic and Mesozoic ammonoids display a more or less strong change in coiling near the termination of growth (e.g., Trueman 1941; Parent 1997; Klug 2001; Klug and Korn 2003). In the earliest ammonoids such as Metabactrites, Anetoceras and Erbenoceras, the last whorl is usually more openly coiled than the preceding ones (e.g., De Baets et al. 2013a, b). One of the most common changes in coiling in planispiral ammonoids is the umbilical egression, i.e. the increase in the relative umbilical width close to adulthood. Lehmann (1981) dubbed this phenomenon "retraction". Conspicuous examples are found within Late Devonian Wocklumeriidae (Ebbighausen and Korn 2007), Middle Triassic Ceratitidae (e.g. Wenger 1957), Late Triassic Haloritidae (Mojsisovics 1882), Middle Jurassic Tulitidae (e.g., Hahn 1971; Zatoń 2008) and Late Cretaceous Acanthoceratidae (Kennedy and Cobban 1976).

The changes in coiling in the terminal whorl of Cretaceous heteromorphs range among the most conspicuous and thus most famous mature modifications. Many taxa formed a U-shaped terminal demi-whorl, which sometimes deviates from the coiling plane of preceding whorls. In the Late Cretaceous Didymoceras, the Ushaped part is separated from a helicospirally coiled preadult shell, whose coiling axis forms an angle of $60-90^{\circ}$ to that of the terminal demi-whorl (e.g. Kennedy et al. 2000). In the Late Cretaceous Pravitoceras, the coiling direction changes in the opposite direction from the penultimate to the terminal demi-whorl (Matsunaga et al. 2008). In the Early Cretaceous Hamulina and Heteroceras, the U-shaped hook represents the largest part of the shell (Orbigny 1850). 
Several evolutionary lineages independently produced small to medium sized forms, in which the terminal whorl is strongly elliptical or even forms a kink. For instance, the last whorl of the Late Devonian Prolobitidae is slightly elliptical and ends in a nearly straight shaft. Simultaneously, the umbilical wall closes the umbilicus (Walton et al. 2010 and references therein). The Permian Hyattoceras produced a similar shell form with the main difference being that the whorl forms a subtriangular cross section about $180^{\circ}$ behind the terminal aperture (marked by a constriction), preceded and followed by a much more rounded cross section (Gemmelaro 1887; Davis 1972; Davis et al. 1969, 1996). A similar morphology evolved convergently in the Triassic families Haloritidae and Lobitidae (e.g., Mojsisovics 1882). In fully grown specimens of both groups, the last whorl is elliptical. Where the whorl height is largest, the whorl width is reduced and the whorl tapers towards the venter, while both before and after this short whorl segment, the venter is more or less broadly rounded. In the Jurassic, a couple of genera evolved comparable morphologies, but in these cases, they represent microconchs of less than $5 \mathrm{~cm}$ diameter and with strong apertural modifications (lappets). In the Middle Jurassic, all representatives of Oecoptychius display a strongly elliptical terminal whorl and some even form a distinct kink a demi-whorl posterior of the terminal aperture (Schweigert and Dietze 1998; Schweigert et al. 2003). Cadomoceras (Middle Jurassic; Schweigert et al. 2007), Sutneria (Late Jurassic; Parent et al. 2008a), and Protophites (Bert 2003) evolved quite similar changes in coiling in the terminal whorl.

Especially in Paleozoic forms, such a change in coiling is not always obvious. In such cases, adulthood/maturity is often reflected in more or less distinct changes in whorl expansion rate. For example, Devonian Anarcestidae commonly have a whorl expansion rate around 1.5. In the terminal whorl, the whorl expansion rate (Raup and Michelson 1965) increases to values around 2 (Klug 2001; Korn 2012). In the Devonian agoniatitids, the whorl expansion rate rises in the preadult whorls. When the specimen approached maturity, this increasing trend is inverted. At least for these Devonian ammonoids, the rule applies that forms with high whorl expansion rates show a terminal decrease while those with low whorl expansion rates display a terminal increase.

\subsubsection{Changes in Ornament}

A change in ornament near the terminal aperture is very common in ammonoids (e.g., Davis et al. 1996). Many show a decrease in ornament strength, especially as far as ribbing is concerned. This applies to such genera as Triassic Ceratites, Jurassic Dactylioceras, and Cretaceous Acanthoceras among many others. In some ammonoid taxa, the ornament became initially stronger and then smoothed directly behind the terminal aperture. In macroconchiate Jurassic perisphinctids, the preadult whorls sometimes carry rather closely spaced fine and sharp ribs, which more or less abruptly change into coarse and broad ribs on the last whorl (variocostation; e.g., Crussoliceras, Lithacoceras, Perisphinctes). Usually, however, the last 10 $20^{\circ}$ behind the terminal aperture are devoid of strong ribs and commonly display tightly spaced growth lines and/or lirae. 


\subsubsection{Terminal Apertural Constriction or Shell Thickening}

A sudden reduction in the whorl cross section at the terminal peristome is very common in the Ammonoidea (e.g., Devonian: Parawocklumeria, Wocklumeria; Permian: Agathiceras, Hyattoceras; Triassic: Arcestes, Lobites; Jurassic: Bullatimorphites, Cadoceras; Cretaceous: Baculites, Saynoceras, Scaphites, Valanginites; e.g., Davitashvili and Khimshiashvili 1954; see Davis et al. 1996 for further examples). In some genera, this constriction is combined with a shell thickening or the terminal shell thickening may appear like a constriction in the internal mould (e.g., Devonian Agoniatites, Manticoceras; e.g., Klug 2001; De Baets et al. 2012).

\subsubsection{Formation of Adult Apertural Modifications}

Changes in the shape of the aperture (Fig. 7.2) are the most conspicuous mature modification. In some taxa, the undulation of the apertural margin with its projections and sinuses increased only slightly, while in others, this undulation became so extreme that long projections formed adjacent to the supposed ocular sinus. In microconchs of Kosmoceras phaeinum, these projections or lappets approached the diameter of the adult shell in length in some specimens (Arkell et al. 1957; Krimholc et al. 1958b; Makowski 1962; Callomon 1963). These extensions of the terminal peristome developed various shapes.

From the Paleozoic, only a few examples have become known. Davis (1972) and Davis et al. $(1969,1996)$ published Permian examples of Adrianites and Hyattoceras with strong projections at the terminal aperture. Zhao and Zheng (1977) introduced the Permian genus Elephantoceras, which is a small, globular form with strong ornament and long apertural lappets. Some Triassic Arcestidae carry strong ventrolateral or ventral projections (Mojsisovics 1882), while the ceratitids often lack strong lappets (e.g. Sun 1928).

Prominent lateral apertural lappets became common among Middle and Late Jurassic microconchs (Keupp and Riedel 2010). In the Haploceratoidea, several microconchs carry drop-shaped lappets, while in many Stephanoceratoidea and Perisphinctoidea, the lappets are rather straight and tongue-shaped (e.g., Zaton 2008, 2010; Tajika et al. 2014). In Oecoptychius, the lateral lappets are hammer-shaped and combined with a ventral hemispherical projection (Schweigert and Dietze 1998; Schweigert et al. 2003, 2007). Another example has been discussed by Keupp and Riedel (2010): in the Middle Jurassic microconch Ebrayiceras, the lateral lappets are very large (half the size of the last whorl) and nearly fused with smaller ventrolateral lappets, thus forming oval ventrolateral openings.

Several groups produced more or less long ventral projections. For example, all species of the Early Jurassic Amaltheidae formed ventral projections when mature. In the Cretaceous, the genus Mortoniceras produced a more or less strongly curved midventral spine (Marcinowski and Wiedmann 1990; Amedro 1992). 

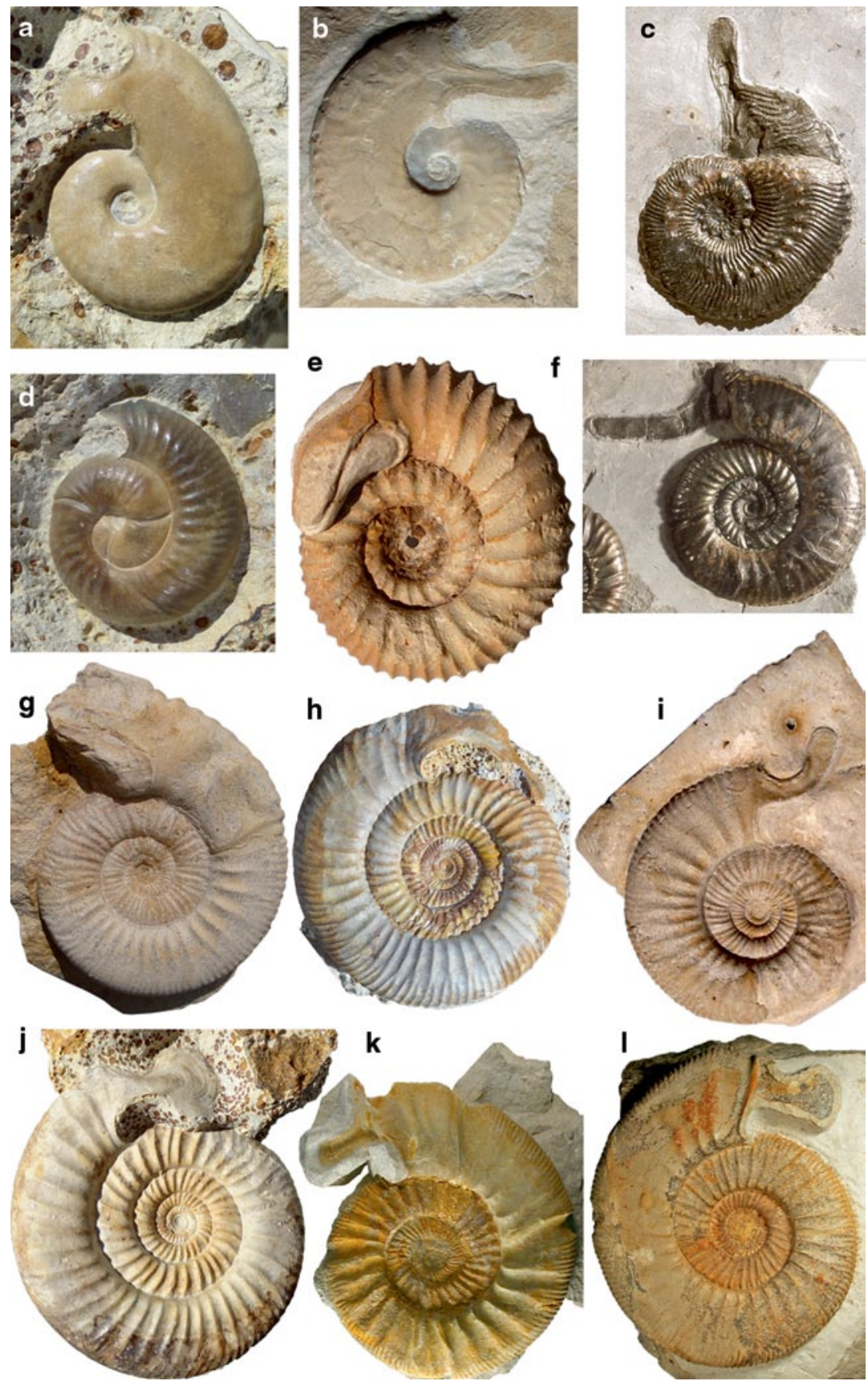

Fig. 7.2 Middle and Late Jurassic microconchs. a Cadomoceras cadomense, Bajocian. b Paralingulaticeras lithographicum, early Tithonian, Mörnsheim, Germany, dm ca. $50 \mathrm{~mm}$. c Kosmoceras "compressum", Callovian. d Neomorphoceras, sp. Oxfordian. e Normannites orbignyi, Bajocian, Thorigné. f Grossouvria sp., Callovian. g Indosphinctes sp., Callovian, Pamproux, with three successive growth halts that all contain lappets. h Cleistosphinctes sp., Bajocian. i Indosphinctes sp., 


\subsubsection{Muscle Scars}

An increasing number of ammonoid species have become known for the preservation of muscle scars (e.g., Doguzhaeva 1981; Doguzhaeva and Kabanov 1988; Doguzhaeva and Mikhailova 1991, 2002; Doguzhaeva and Mutvei 1991, 1993, 1996; Tanabe et al. 1998; Kennedy et al. 2002; Richter 2002; Klug et al. 2008 Chap. 2.4). In most cases, the muscle scars became visible in specimens that were adult. This can be explained by the fact that in mollusks, the secretion of carbonate is commonly linked with muscle attachment, be it at the aperture or at muscle attachment sites. The longer the muscles stayed at the same place, the more carbonate was secreted, thus increasing the likelihood of its preservation. In preadult growth stages, the interim attachment sites apparently existed too briefly in one place to allow the deposition of a sufficient amount of aragonite to become visibly preserved. An additional bias might be the size of the specimen, although some small (probably adult) cheiloceratids $(<30 \mathrm{~mm})$ have been reported (Richter 2002) that nicely show muscle attachment structures.

An illustrative example of sexual dimorphism in muscle scars, with connotations in soft-body organization, was described by Palframan (1969: text-fig. 11) from adult macro- and microconchs of Hecticoceras brightii. Besides the usual ventrolateral muscle scars in both dimorphs (Doguzhaeva and Mutvei 1991), the macroconchs have an additional ventrolateral scar behind the peristome. The microconchs also bear these additional scars but extended ventro-laterally and projected on the flanks until, at least, the umbilical shoulder.

\subsubsection{Colour Pattern}

Colour patterns are rarely preserved in ammonoids (e.g., Mapes and Davis 1996; Mapes and Larson 2015). Adult modifications of these patterns are even rarer. We are aware of only the one record already reported by Mapes and Davis (1996), namely Mapes and Sneck (1987), who described an Owenites in which the transverse color bands were more tightly spaced near the terminal aperture.

\subsubsection{The Black Layer}

The black layer is well-known from modern nautilids (Ward 1987). In shells of adult nautilids, a black chitinous layer less than $0.5 \mathrm{~mm}$ thick in the dorsal part of the shell extends beyond the apertural edge. It covers a tongue-shaped surface with an adult thickening, which is formed at the termination of growth. A similar black layer has been found in various ammonoids (Fig. 7.3), including e.g., Devo-

Callovian, Pamproux, with bent lappet. j Bigotites sp., Bajocian. k Parataxioceras latifasciculatum, middle Kimmeridgian, Gräfenberg, Germany, dm ca. 145 mm. I Parataxioceras cf. lothari, middle Kimmeridgian, Geisingen, Germany, dm ca. 100 mm. a, d, h, j Ste. Honorine Des Pertes, France, col. C. Obrist. B, K, L, col. V. Schlampp. C, F, Aichelberg, Germany, from Dietl (2013). E, G, I, col. P. Branger 

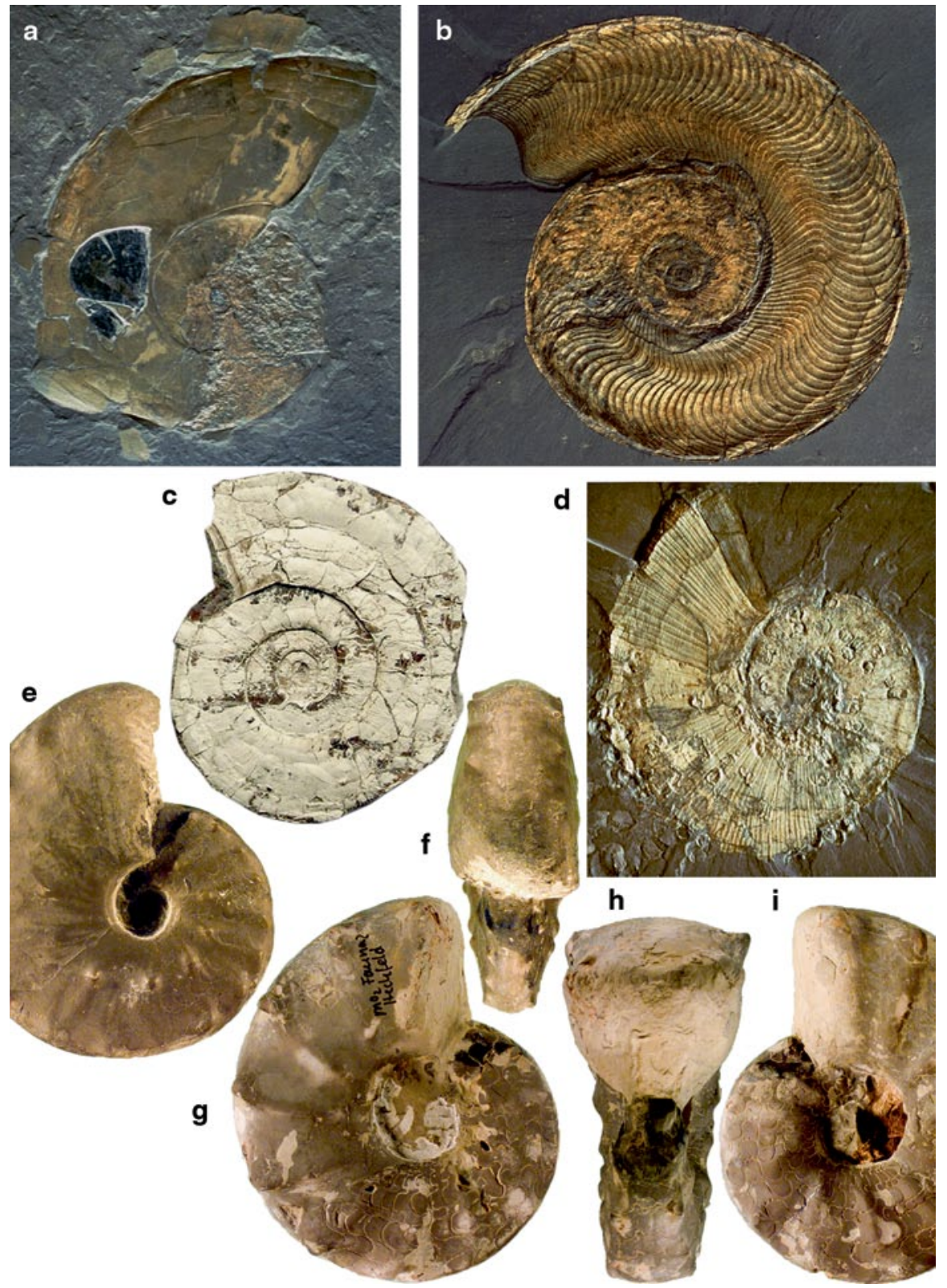

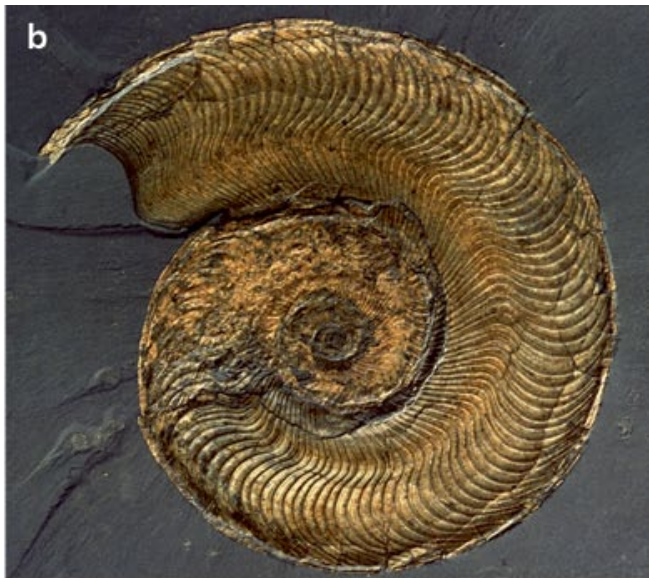

d

Fig. 7.3 Black layer and black band in Mesozoic ammonoids (a-d from Klug et al. 2007; e-i from Klug et al. 2004). a Phylloceras heterophyllum, SMNS 26462, tenuicostatum Zone, Ohmden, Germany; $\mathrm{dm} 87 \mathrm{~cm}$. Note the jaws and the black band. b Harpoceras falciferum, falciferum-bifrons Zone, Holzmaden, dm $24 \mathrm{~cm}$. c Psiloceras planorbis, PIMUZ 6519; planorbis Zone, Hettangian, Blue Anchor, Somerset, UK, dm $45 \mathrm{~mm}$. Note the black band and black layer. d Lytoceras ceratophagum, SMNS 26465; falciferum Zone, Toarcian, Ohmden, Germany; dm $41 \mathrm{~cm}$. e, f Paraceratites atavus, lateral and dorsal views, SMNS 24503, atavus Zone, Neckarrems, col. M. Warth; $\mathrm{dm} 61 \mathrm{~mm}$. g-i, Ceratites spinosus, lateral and dorsal views, SMNS 25255-33, spinosus Zone, Heckfeld; dm 102 mm. Images: a, b Staatliches Museum für Naturkunde Stuttgart. d Urweltmuseum Hauff. c T. Galfetti. e-i W. Gerber 
nian gephuroceratids (Keupp 2000), Triassic ceratitids (Klug et al. 2004), as well as Jurassic ammonites (Klug et al. 2007) and is considered as either homologous or convergent with the structure in nautilids. Of the criteria of homology, only those of position and specific structure are fulfilled, since transitional states are missing (Klug et al. 2004). Nevertheless, it is likely that the anterior edge of the black layer served for the attachment of the dorsal mantle.

\subsubsection{The Black Band}

The black band is a thin organic coating on the shell, which forms a narrow band surrounding the adult aperture in some cephalopods; it is sometimes found in modern nautilids (Ward 1987) and rarely in ammonoids (Klug 2004; Klug et al. 2007). Like the black layer, it is black due to its melanin content. So far, it has been found in Psiloceras, Phylloceras, Lytoceras, and Harpoceras from the Early Jurassic (Fig. 7.3) and two questionable specimens from the Triassic (Klug 2004; Klug et al. 2007). It is apparently linked with the adult cessation of growth and in modern nautilids, the black band has been recorded from adult females, although not all individuals appear to develop this structure. Like the black layer, the black band is probably also linked with mantle attachment at the aperture.

Davis (1972), summarized in Davis et al. (1996, p. 469), found indications for "an actual change in the nature of shell deposition late in ontogeny". Accordingly, the shells of adult Adrianites and other Permian ammonoids displayed small "pits in the internal mold". Davis et al. (1996) suggested that these structures are possibly homologous to the apertural attachment of the mantle at the black band in mature modern nautilids.

\subsubsection{The Wrinkle Layer}

The wrinkle layer is a structure of uncertain function that occurs in a number of ammonoids in the form of irregular shell wrinkles in the dorsal part of the shell, usually near maturity (Barrande 1877; House 1970; Walliser 1970; Senior 1971; Doguzhaeva 1981; Kulicki et al. 2001). Strength of the wrinkle layer is a character that is rarely preserved and thus of limited use. The wrinkle layer is predominantly found in nearly adult or fully mature specimens (Korn et al. 2014). Kulicki et al. (2001) already pointed out that the wrinkle layer might be comparable or even homologous to the black layer of nautilids.

\subsubsection{Constructional and Functional Morphology}

Some of the mature modifications of ammonoid shells are so profound that it is hard to imagine that the altered adult morphology did not affect the life style of the ammonoid and thus their evolution. Recurrent morphologies (such as convergent 
evolution of apertural lappets) support this hypothesis. Several suggestions have been made with regard to functional as well as constructional interpretations of the modified adult morphology (Tajika et al. 2014): (1) change of habitat (Davis et al. 1996); (2) defense against predators (Keupp and Riedel 2010); (3) sexual display (Keupp and Riedel 2010); (4) attachment of reproductive organs (a modified arm; Landman et al. 2012); (5) change in locomotion/behavior (Klug 2001); (6) fast and metabolically economic construction of the terminal shell segment; (7) fabricational noise with a lack of function (Seilacher 1974).

(1) The change of habitat did possibly occur since the relative abundance of macroconchs or microconchs varies between localities. Especially in such cases with a large difference in adult size, it might have been important that the sexes stayed separate until the time of mating in order to reduce the time of exposure to potential "sexual" cannibalism (Hanlon and Forsythe 2008; Keupp and Riedel 2010). Nevertheless, this hypothesis is difficult to test.

(2) Many ammonoid species reinforced their terminal apertures by shell thickenings (e.g., Agoniatites, Arcestes, Manticoceras). Even constrictions without shell thickenings might have increased the resistance of the aperture against breakage by predators (Landman and Waage 1986; Keupp and Riedel 2010; Keupp 2012). It is, however, not possible at this point to test whether these modifications are effects of the terminal deceleration of growth or whether they represented antipredatory adaptations. Seilacher (1974) argued against such a function in the microconchs because in his opinion, such defensive structures would be more meaningful in the females.

(3) and (4) are nice ad hoc hypotheses and are difficult to test, especially with the lack of knowledge of the soft parts in general and the reproductive organs in particular. The extreme differences between some antidimorphs (especially Phlycticeras and Oecoptychius) suggest a comparison to the modern octobrachian Argonauta, in which the male measures only $2 \mathrm{~cm}$ in length, while the female may reach over $40 \mathrm{~cm}$, when the shell is included. The male of Argonauta has a modified arm (hectocotylus), which is stored in a ventral sac prior to mating. This structure is somewhat reminiscent of some of the apertural modifications. Landman et al. (2012) hypothesized that ammonites with a high aperture angle had this type of arm to improve mating efficiency. Nevertheless, direct evidence for such a convergence is still missing.

(5) Klug (2001) showed that the whorl expansion rate in Middle Devonian ammonoids changed close to the cessation of growth. He argued that this change in whorl expansion rate was linked to a change in body chamber length, which, in turn, caused a change in the syn vivo orientation of the shell. In the main lineages of Devonian ammonoids, the adult aperture would have moved to a more horizontal position than in preceding growth stages (see also Korn and Klug 2002; Klug and Korn 2004). The latter authors concluded that this change in shell orientation improved mobility and manoeuvrability, both valuable traits to find a mating partner and good spawning grounds.

Tajika et al. (2014) empirically tested the effect of apertural lappets in the Middle Jurassic Normannites and found that absence or presence of these lappets would not 
have altered the shell orientation significantly. Therefore, these lappets most likely did not serve the function of altering the shell orientation.

(6) Microconchs of the Haploceratoidea and Perisphinctoidea produced a pair of lateral projections or lappets in the peristome (Fig. 7.2), and most frequently their body chambers are shorter than those of macroconchs. Thus, the pair of lappets could be interpreted as the terminal shell segment for accommodating the cephalic portion of the animal. This "shell segment" could have been secreted rapidly and economically considering the low amount of aragonite necessary compared to a complete "tubular" shell segment. The muscle scars around the peristome of the haploceratoid Hecticoceras brigthii (see above; Palframan 1969) would indicate additional muscle development providing for support and mobility of the cephalic portion of the body.

\subsection{Dimorphism}

As far as the history of research on ammonoid dimorphism is concerned, we only want to mention briefly that de Blainville (1840) and d'Orbigny (1847, p. 441) were probably the first to discuss sexual dimorphism in ammonoids (see also Foord and Crick 1897; Haug 1897). In any case, broader interest in the topic grew in with the important monographs of Makowski (1962) and Callomon (1963).

Commonly, there is a smaller and a larger form in those taxa in which dimorphism is more apparent due to clear differences combined with equally visible shared juvenile characters. For these, Callomon (1955) introduced the widely used terms microconch and macroconch, respectively. These are called antidimorphs.

\subsubsection{Monomorphism, Dimorphism, and Polymorphism}

Adults of the two sexes of any given animal species may have similar or different shapes. If they are monomorphic, there is no significant difference in adult shape. In the case of dimorphism, two different adult morphologies can develop from morphologically similar juveniles (Davis 1972). In ammonoids, these are traditionally called microconchs (for the smaller variant) and macroconchs for the larger variant. The corresponding pairs are named antidimorphs. In the case of polymorphism, there are more than two (usually three or more) different adult morphologies. Polymorphism in modern biology refers to natural genetic variation (with phenotypic expression or not), undetectable in fossils; here, we use the term to refer to morphological differences between supposed conspecific phenotypes, which could have either a genetic or an environmental cause (compare De Baets et al. 2015a).

As did our forerunners (Davis et al. 1996), we will not repeat all details of the research on dimorphism from its beginnings in the nineteenth century (de Blainville 
1840; Orbigny 1847). Instead, we recommend looking up these details in the excellent monographs by Makowski (1962) and Callomon (1963).

There are numerous articles dealing with polymorphism (McCaleb and Furnish 1964; McCaleb et al. 1964; Ivanov 1971, 1975, 1985; Kant 1973; Hirano 1978, 1979; Matyja 1986, 1994; Makowski 1991; Melendez and Fontana 1993). According to these authors, some Jurassic and Cretaceous ammonoids produced more than two forms. After Ivanov $(1971,1975,1985)$ had dubbed exceptionally large forms "megaconchs", Matyja (1986, 1994) introduced the term "miniconchs" for exceptionally small specimens. He suggested that certain environmental parameters controlled the point of maturation, inducing monomorphism, dimorphism or polymorphism. In his work on modern coleoids, Mangold-Wirz (1963), Mangold-Wirz et al. (1969), as well as Mangold (1987) demonstrated how hormones produced by the optic gland can control the timing of maturation and thus size depending on the developmental state of the gonads. It was also demonstrated for Recent coleoids in captivity that environmental factors such as light intensity, temperature or food availability can have an effect on maturation and therefore adult size (e.g., Gabr et al. 1998; Moltschaniwskyj and Martínez 1998; Tafur et al. 2001; Jackson and Moltschaniwskyj 2002). Callomon (1988) criticized Matyja's ideas about polymorphism, suggesting that a larger database would be needed to test some of his hypotheses (see also De Baets et al. 2015a). Later, Dzik (1990a), analysing a rich collection of Callovian Quenstedtoceras ammonites from the classic locality at Łuków in eastern Poland, did not find any evidence for polymorphism.

\subsubsection{Classification of Dimorphism}

Bearing in mind the vast diversity and impressive variability of ammonoids, it is not surprising that dimorphism is far from uniform within this group. Consequently, various authors have attempted to meaningfully classify ammonoid dimorphism. In his pioneer monograph, Makowski (1962) introduced two kinds of dimorphs. In Type A, the microconch has five (four) to six whorls and the macroconch has seven (six) to nine whorls. Type B microconchs have seven (six) to nine whorls and the macroconchs have one additional whorl. Guex (1968) added Type O, where the microconch has three to four whorls.

Westermann (1964a) and Houša (1965) also differentiated between two types of dimorphism, where one type differs only in size, while the other differs in size and other characters, especially in the shape of the peristome. Zeiss (1969) added a third group to these two, in which dimorphism was not recognized. This leads to the question, whether dimorphism is the rule and that it only can sometimes not be identified due to taphonomic processes (loss of soft-tissues and subtle conch characters). In that case, a lot of work would await ammonoid researchers, because many more cases of dimorphism would await their detection. 


\subsubsection{Criteria for Dimorphism}

In order to verify the hypothesis of conspecificity of two or more different adult forms, the following criteria (Makowski 1962; Callomon 1963, 1981; Westermann 1964a; Davis 1972; Davis et al. 1996) should be fulfilled:

1. The antidimorphs should differ in adult morphology;

2. They should have more or less identical early developmental stages;

3. They should occur in strata of the same stratigraphic range;

4. They should have overlapping geographic occurences;

5. They should have the same ancestors;

6. The ratio of numbers of micro- to macroconchs should be about the same through time and throughout the evolution of their clade.

Most ammonoid workers would agree on points (1) and (2). However, a few exceptions exist. McCaleb (1968) stated that in the Late Carboniferous Syngastrioceras oblatum, the morphological differences between macro- and microconch are larger in juvenile/preadult growth stages than in the mature stage/the last whorl. Similarly, Rein $(2001,2003)$ suggested that species of the Middle Triassic genus Ceratites show a similar morphological separation of the antidimorphs. He introduced the terms E- (referring to the smooth species $C$. enodis) and P-morph (referring to the strongly ornamented species $C$. posseckeri) for forms with smooth or strongly ornamented preadult whorls. Although further work on this issue would be welcome, we would like to point out that the coiled shells of many mollusks display the highest degree of intraspecific variability in preadult whorls (e.g., Urdy et al. 2010a, b; De Baets et al. 2015). Therefore, the question arises whether these two exceptions, where supposedly the middle whorls differ in antidimorphs instead of the adult morphology, are artifacts from normal intraspecific variability (Urlichs 2009).

Davis et al. (1996) pointed out that differences in geographical occurrences (point 4) of the antidimorphs would not be surprising since their differing morphologies might reflect differing ecological requirements. This might hold true for parts of their life but at least at some point, males and females had to meet in order to reproduce. It is still conceivable that the intersexual differences in behaviour and habitat varied between species, when the extreme differences in dimorphism throughout the ammonoid clade are taken into account.

For various reasons, the morphologic evolutionary rates among the microconch part of a lineage may seem (1) higher (Lehmann 1981; Davis et al. 1996) or (2) lower (e.g., Callomon 1969, Westermann and Riccardi 1979: p. 134) than those of the macroconchs. In the first case, this might be a primary signal, i.e. the microconchs evolved morphologically faster because the mature modifications were directly prone to sexual selection or of great importance for reproduction. Alternatively, this seeming difference in evolutionary rates might be an artifact because the microconchs might attract more attention due to their peculiar morphology, or because evolutionary change is easier to track in microconchs since they display more distinct morphological character states. In any case, these differences in mor- 
phological evolution between antidimorphs may hamper evolutionary studies. In studies of dimorphism, it is important to know the phylogenetic framework of the ammonoid lineage under consideration (point 5), because this knowledge optimally contains information on the development of ancestors and other members of the clade, as well as plesiomorphies and degrees of conservativeness of traits. Finally, this phylogenetic test is needed to falsify the hypothesis that the antidimorphs under consideration indeed belong to two separate species.

In the second case, the slower morphologic evolutionary change of the microconchs with respect to the macroconchs produced the opposite pattern, like a morphological stasis of the males. This pattern is produced in lineages where the main morphologic changes developed in the subadult and/or adult ontogeny of the macroconchs. The microconchs typically stop their growth in the early ontogeny of the species, thus not reflecting the changes seen in the macroconchs.

Of course, there may be traits that are not preserved or only rarely or poorly preserved, which could potentially be used to discriminate between antidimorphs, where shell characters alone do not suffice. Till $(1909,1910)$ searched for dimorphic characters in the jaws, while Parent et al. (2013, p. 32) found evidence of sexual dimorphism in the aptychus (Praestriaptychus) of Lithacoceras [M]/Silicisphinctes [m]. Mapes and Sneck (1987) found two kinds of colour patterns in Owenites. Nothing is known about differences in the soft part anatomy between the antidimorphs and we can only hope that one day, exceptionally preserved soft-tissue ammonoids will be discovered, shedding more light on the internal organisation of ammonoids.

\subsubsection{Sexing of Ammonoid Antidimorphs}

For some, sexing of ammonoid shells seems a trivial task and it happens quite commonly that the microconch is automatically considered the male. This confidence is surprising because the ultimate evidence, namely soft-tissue preservation of reproductive organs in the antidimorphs, is still missing. The background for this slightly premature conclusion is probably the actualistic comparison with some Recent octobrachians. In Argonauta, which was already mentioned above, the size differences are just as striking as in Ocythoe tuberculata, where the female is $1 \mathrm{~m}$ long and so ten times as long as the male (Makowski 1962; Wells 1962, 1966; Mangold-Wirz 1963; Westermann 1969a; Mangold-Wirz et al. 1969; Roper and Sweeney 1975). By contrast, the male is slightly larger in Recent Nautilida (Willey 1895, 1902; Saunders and Spinosa 1978; Saunders and Ward 1987; Hayasaka et al. 1987), but they have a different reproductive strategy. Remarkably, aptychi have been interpreted as protecting the nidamental glands (Keferstein 1866) and Siebold (1848) even suggested that the aptychi were the micromorphic males. Nowadays, there is not much doubt that the aptychi were part of the buccal apparatus and had nothing to do with reproduction.

Numerical ratios between the antidimorphs were another line of evidence that has been explored to assign sexes to each of them. Davis et al. (1996) gave an overview 
of the contradicting results of various authors who worked on ammonoids or on Recent cephalopods (Willey 1902; Coëmme 1917; Pelseneer 1926; Mangold-Wirz 1963; Makowski 1962; Mangold-Wirz et al. 1969; Westermann 1969a; Saunders and Ward 1987; Hayasaka et al. 1987). In ammonoids, the results are biased by the fact that the numerical ratios are influenced by facies and taphonomy (e.g., Callomon 1981, 1985). The most plausible line of reasoning appears to be that of Lehmann (1981), who inferred that the macroconchs were the females because the maturation of eggs takes longer than that of spermatophores, implying a longer lifespan and thus a larger adult size. Moreover, reproductive organs of females (e.g., ovaries, nidamentary glands) are often larger than the simpler reproductive organs of males.

Ammonoid eggs have been reported by several authors (Lehmann 1966; Müller 1969; Zakharov 1969; Maeda 1991; Urlichs 2009; Etches et al. 2009; Landman et al. 2010; Klug et al. 2012). In spite of these findings, there is as yet no report of a discovery of eggs within an ammonoid shell that is free of doubt (De Baets et al. 2015b). Either the preservation is insufficient to detect whether they are truly ammonoid eggs or it is unclear if such an egg mass is really in situ within the ammonoid.

\subsubsection{Development and Dimorphism}

To detect dimorphism in ammonoids, knowledge of their ontogeny is needed (see the criteria for dimorphism). Developmental heterochronies have been suggested as processes generating the differences between the antidimorphs (Gould 1977; Shea 1986). Davis et al. (1996) discussed whether microconchs were accordingly progenetic and/or hypomorphic (Landman et al. 1991; Neige 1992).

In any case, many antidimorphs display a congruent pattern of development of various shell parameters, which diverge at some point with the microconchs maturing and stopping growth at a size-wise earlier point (e.g., Makowski 1962; Guex 1973; Parent 1997; Parent et al. 2008b, 2009).

Plotting certain shell parameters throughout ontogeny (versus diameter) is an important and powerful method to demonstrate dimorphism. The graphs in Fig. 7.4 illustrate some of the patterns and features discussed above from a moderately large sample of the Early Callovian sphaeroceratid Eurycephalites gottschei. The growth rate measured by the relative whorl ventral height is dimorphic (Fig. 7.4a upper) with an increase in both dimorphs up to about $10 \mathrm{~mm}$ diameter, after which both dimorphs inverted the trend; from a diameter of about $18 \mathrm{~mm}$ onward, the microconch diverged by increasing the rate of growth towards the peristome (Parent 1997). The shape of the whorl cross section changed strongly during growth, but the ontogenetic trajectory is the same in micro- and macroconchs, i.e., monomorphic (Fig. 7.4a bottom). The ventral ribbing is another feature that is dimorphic with a similar trend to that found in the growth rate (Fig. 7.4b). The microconch trend diverged from a diameter of $18 \mathrm{~mm}$ compared to that of the macroconch, which is taken as the standard. 

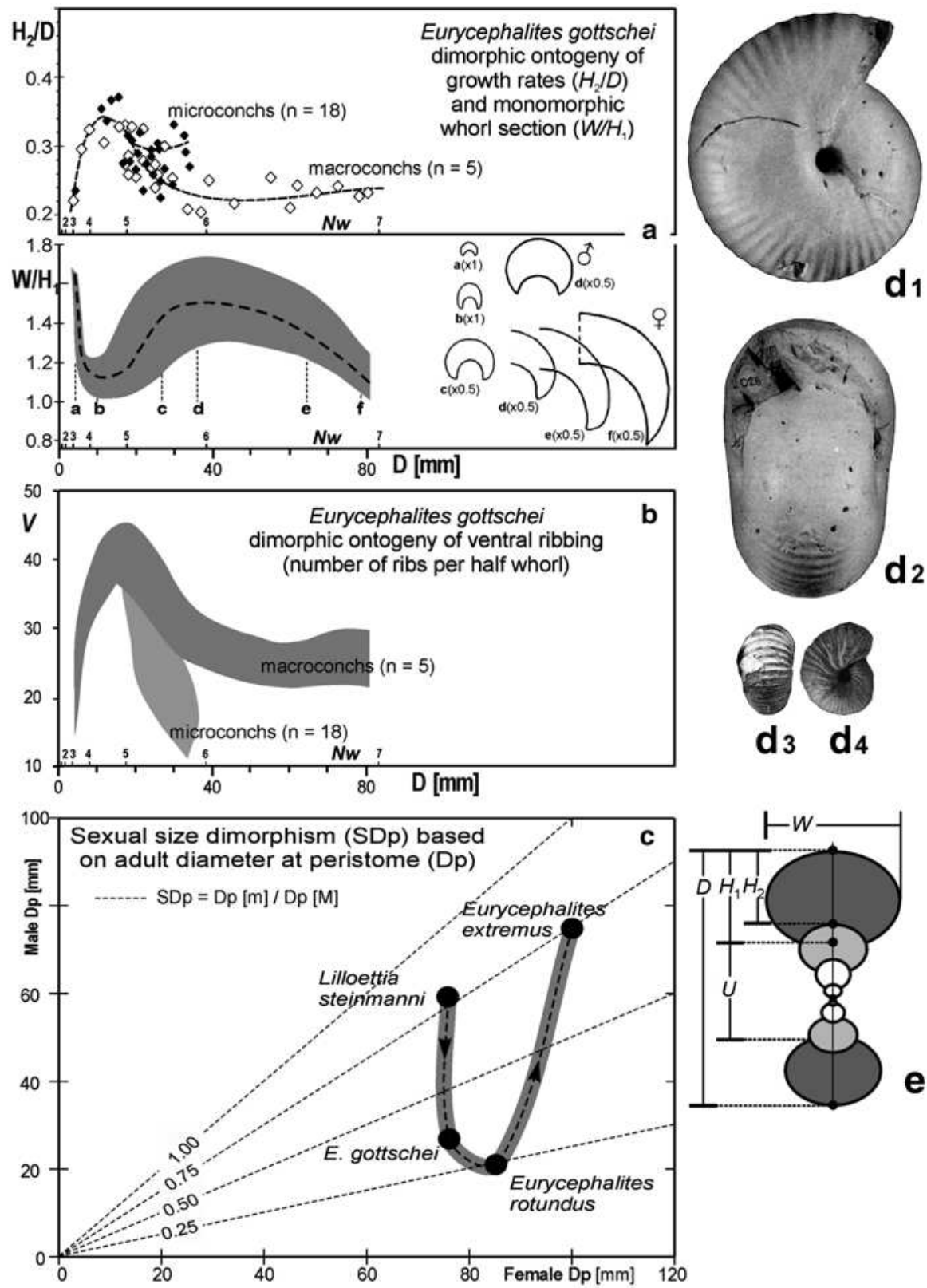

Fig. 7.4 Dimorphism of Eurycephalites gottschei (Tornquist 1898) [Sphaeroceratidae]. a (upper): dimorphic ontogeny of the growth rate measured as $\mathrm{H}_{2} / \mathrm{D}$ versus diameter $(D)$ and whorl number $(N w) ; \mathbf{a}($ lower $)$, monomorphic ontogeny of the whorl section measured by $\mathrm{W} / \mathrm{H}_{1}$ versus $D$ and $N w$ (grey area) and selected cross-sections $(\mathbf{a}-\mathbf{f})$. b dimorphic ontogeny of ventral rib number per half whorl (V) versus $D$ and $N w$. c evolution of the sexual size dimorphism in the lineage Lilloettia (late Bathonian)-Eurycephalites (Early Callovian). d dimorphic pair, a complete adult macroconch $\left(\mathbf{d}_{\mathbf{1}}-\mathbf{d}_{\mathbf{2}}\right)$ and an adult microconch $\left(\mathbf{d}_{3}-\mathbf{d}_{\mathbf{4}}\right)$, both $\times 0.4$. e shell size dimensions. $\mathbf{a}-\mathbf{b}, \mathbf{d}-\mathbf{e}$ modified from Parent (1997). c from data in Parent (1998) 


\subsubsection{Evolution of Dimorphism}

Evolution of sexual dimorphism is a complex and interesting aspect in ammonoid paleobiology. However, it is also very demanding with respect to material and raw data. One of the most detailed studies is that of Schweigert and Dietze (1998) for the evolution of Phlycticeras/Oecoptychius. Sexual size dimorphism, the feature more readily captured by the observer, shows important changes during the evolution of many ammonoid lineages. One of them is the lineage Lilloettia (Late Bathonian)Eurycephalites (Early Callovian), which shows important changes in the ratio of the adult micro- versus macroconch size (Fig. 7.4c), ranging from microconchs of three-quarters (L. steinmanni and E. extremus) to one third (E. gottschei and E. rotundus) the size of the macroconch.

\subsubsection{Occurrences of Dimorphism}

From the Hettangian onwards, Guex (1981) stated that, except for the phylloceratids, the majority of ammonites do show dimorphism. It thus appears that at least in the Jurassic and Cretaceous, whether dimorphism is detected or not largely depends on quality and quantity of the material plus the motivation of a researcher to quantitatively analyze an ammonite lineage. Presuming that the dimorphism of ammonoids really represents the different sexes, a more or less omnipresent dimorphism appears not so surprising, especially because most modern cephalopods also show more or less strong dimorphism.

In contrast to the work of Davis et al. (1996), we will not list mature modifications in great taxonomic detail in the text below, because it appears that the majority of ammonoids actually did undergo some kind of terminal growth and thus produced mature modifications. It is striking that strong apertural modifications became common only in the Jurassic, although a few Permian species (Zhao and Zheng 1977), as well as some Paleozoic nautilids (e.g., Dzik 1984) did produce strong apertural appendages.

\subsubsection{Palaeozoic Dimorphism}

Devonian: For the earliest, loosely coiled ammonoids, De Baets et al. (2013a) tested for sexual morphism in Moroccan Erbenoceras and Anetoceras and found no clear indication of it. It could be argued that dimorphism might be camouflaged in the strong intraspecific variability (Kakabadze 2004 discussed dimorphism in relation to variability) of this group, but among these two genera, the intrageneric and probably also intraspecific variability is markedly reduced toward the end of growth. Not much has been published on Devonian dimorphism after Makowski (1962) had listed several cases (Table 7.1). Walliser (1963) only shortly mentioned its existence without any detail. Later, Makowski (1991) determined the relative abundance of 
Table 7.1 Sexual dimorphism in Devonian to Triassic ammonoids

\begin{tabular}{l|l|l|l|l}
\hline Superfamily & Family & Genus & Age & Source \\
\hline Tornoceratoidea & Tornoceratidae & Tornoceras & Famennian & Makowski 1962 \\
\hline Cheiloceratoidea & Cheiloceratidae & Cheiloceras & Famennian & Makowski 1962 \\
\hline & Gephuroceratidae & Manticoceras & Frasnian & Makowski 1962 \\
\hline Ceratitoidea & Acrochordiceratidae & Acrochordiceras & Anisian & Dzik 1990b \\
\hline & Ceratitidae & Ceratites & $\begin{array}{l}\text { Anisian, } \\
\text { Ladinian }\end{array}$ & $\begin{array}{l}\text { Müller 1969; } \\
\text { Rein 2001, 2003; } \\
\text { Urlichs 2009 }\end{array}$ \\
\hline
\end{tabular}

micro- versus macrococonchs in various species of Tornoceras. In T. frechi parvum, he found $28 \%$ macroconchs $(n=95)$, in T. subacutum there were $47 \%$ macroconchs $(n=65)$, and in T. sublentiforme, macroconchs varied between $40 \%(n=133)$ and $45 \%(n=95)$.

Most authors have focused on descriptions of adult modifications (Table 7.2; e.g., Ruzhencev 1962; Korn 1992). Septal crowding has been mentioned commonly (e.g., Korn and Titus 2006; Ebbighausen and Korn 2007; Kraft et al. 2008), elliptical coiling is common in some clymeniids (e.g., Ebbighausen and Korn 2007), increasing umbilical width is characteristic for the earliest, loosely coiled ammonoids (e.g., De Baets et al. 2013a, b), and, of course, changes in ornament spacing have been documented (Fig. 7.5).

Carboniferous: Remarkably, we have not found an unequivocal report on ammonoid dimorphism in the Carboniferous (Nettleship and Mapes 1993). Davis et al. (1996) mentioned the work of Trewin (1970), who suggested that Eumorphoceras produced antidimorphs, but he used poorly preserved materials. Frest et al. (1981) examined Late Pennsylvanian Maximites oklahomensis and found that $40 \%$ of the examined specimens belonged to "form a", which might be the macroconch according to its less strong adult modifications (Davis et al. 1996).

In some taxa, a strong wrinkle layer was secreted when the specimen approached maturity (Korn et al. 2014 and references therein). Septal crowding is also not rare (e.g. Korn et al. 2010), although we have to repeat that its value to determine maturity is limited (Kraft et al. 2008). Umbilical egression (Fig. 7.5; e.g., Frest et al. 1981) and other changes in coiling (e.g., Ruzhencev 1962) also occur in Carboniferous forms, which are visible in some of the cross sections figured in Korn et al. (2010). Ruzhencev (1962) illustrated Dombarites, Homoceras, and Praedarelites, which formed ventral keels near maturity.

Permian: Although many Permian ammonoids are known to have formed distinct mature modifications (Table 7.3, Fig. 7.5; Miller and Furnish 1940; Miller 1944; Ruzhencev 1962; Davis 1972; Zhao and Zheng 1977; Frest et al. 1981; Zhou 1985; Schiappa et al. 1995), not much has been published, suggesting the presence of dimorphism of the shell. Davis et al. $(1969,1996)$ and Davis $(1972)$ counted the specimens of Permian Agathiceras uralicum and found $75 \%$ macroconchs $(n=110)$. Table 7.3 lists mature modifications (modified from Davis et al. 1996). 
Table 7.2 Mature modifications in Devonian and Carboniferous ammonoids

\begin{tabular}{|c|c|c|c|c|c|c|c|c|}
\hline 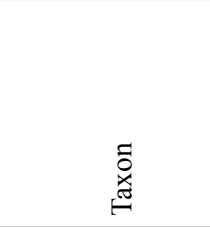 & ن & $\begin{array}{l}0 \\
.0 \\
.0 \\
.00 \\
0 \\
0 \\
0 \\
0\end{array}$ & 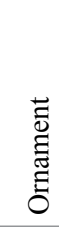 & 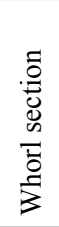 & 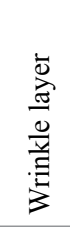 & 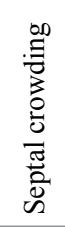 & 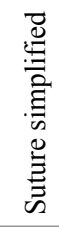 & 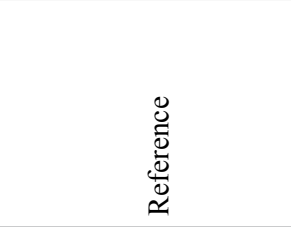 \\
\hline \multicolumn{9}{|l|}{ Anetoceratidae } \\
\hline Anetoceras & $\bullet$ & & $\bullet$ & & & $\bullet$ & & De Baets et al. 2013a, b \\
\hline Erbenoceras & $\bullet$ & & $\bullet$ & & & $\bullet$ & & De Baets et al. 2013a, b \\
\hline \multicolumn{9}{|l|}{ Anarcestidae } \\
\hline Sellanarcestes & $\bullet$ & & & $\bullet$ & & $\bullet$ & & Klug 2001 \\
\hline \multicolumn{9}{|l|}{ Agoniatitidae } \\
\hline Agoniatites & $\bullet$ & $\bullet$ & $\bullet$ & & & $\bullet$ & & Klug 2001 \\
\hline \multicolumn{9}{|l|}{ Gephuroceratidae } \\
\hline Manticoceras & $\bullet$ & $\bullet$ & & & & & & Korn and Klug 2007 \\
\hline \multicolumn{9}{|l|}{ Prolobitidae } \\
\hline Prolobites & $\bullet$ & $\bullet$ & $\bullet$ & $\bullet$ & & $\bullet$ & & Bogoslovsky 1969 \\
\hline \multicolumn{9}{|l|}{ Wocklumerioidea } \\
\hline Wocklumeria & $\bullet$ & $\bullet$ & & & & $\bullet$ & $\bullet$ & $\begin{array}{l}\text { Ebbighausen and Korn } \\
2007\end{array}$ \\
\hline Kamptoclymenia & $\bullet$ & $\bullet$ & $\bullet$ & & & & & Schindewolf 1937 \\
\hline \multicolumn{9}{|l|}{ Pericyclidae } \\
\hline Oaoufilalites & $\bullet$ & & & & & $\bullet$ & & $\begin{array}{l}\text { Korn and Ebbighausen } \\
2008\end{array}$ \\
\hline \multicolumn{9}{|l|}{ Maxigoniatitidae } \\
\hline Maxigoniatites & $\bullet$ & & & & $\bullet$ & & & Korn et al. 1999 \\
\hline \multicolumn{9}{|l|}{ Girtyoceratidae } \\
\hline Calygirtyoceras & $\bullet$ & & & & & & & Korn et al. 1999 \\
\hline
\end{tabular}

Since the account of Davis et al. (1996) appeared, not a lot of new data have been published and it appears that these are still insufficient to analyze evolutionary trends in Paleozoic dimorphism. Accordingly, McCaleb's (1968, p. 29) statement that "dimorphism is a predominant feature at the inception of an evolutionary lineage and decreases through phylogeny" appears premature at best, if not wrong.

\subsubsection{Triassic Dimorphism}

Davis et al. (1996) listed mature modifications in Triassic ammonoids in relation to their shell shape (Table 7.4, Fig. 7.6). This information is summarized in Table 7.4. In spite of the sometimes quite conspicuous adult modifications and the incredible diversity as well as morphological disparity of Triassic ammonoids, reliably dem- 


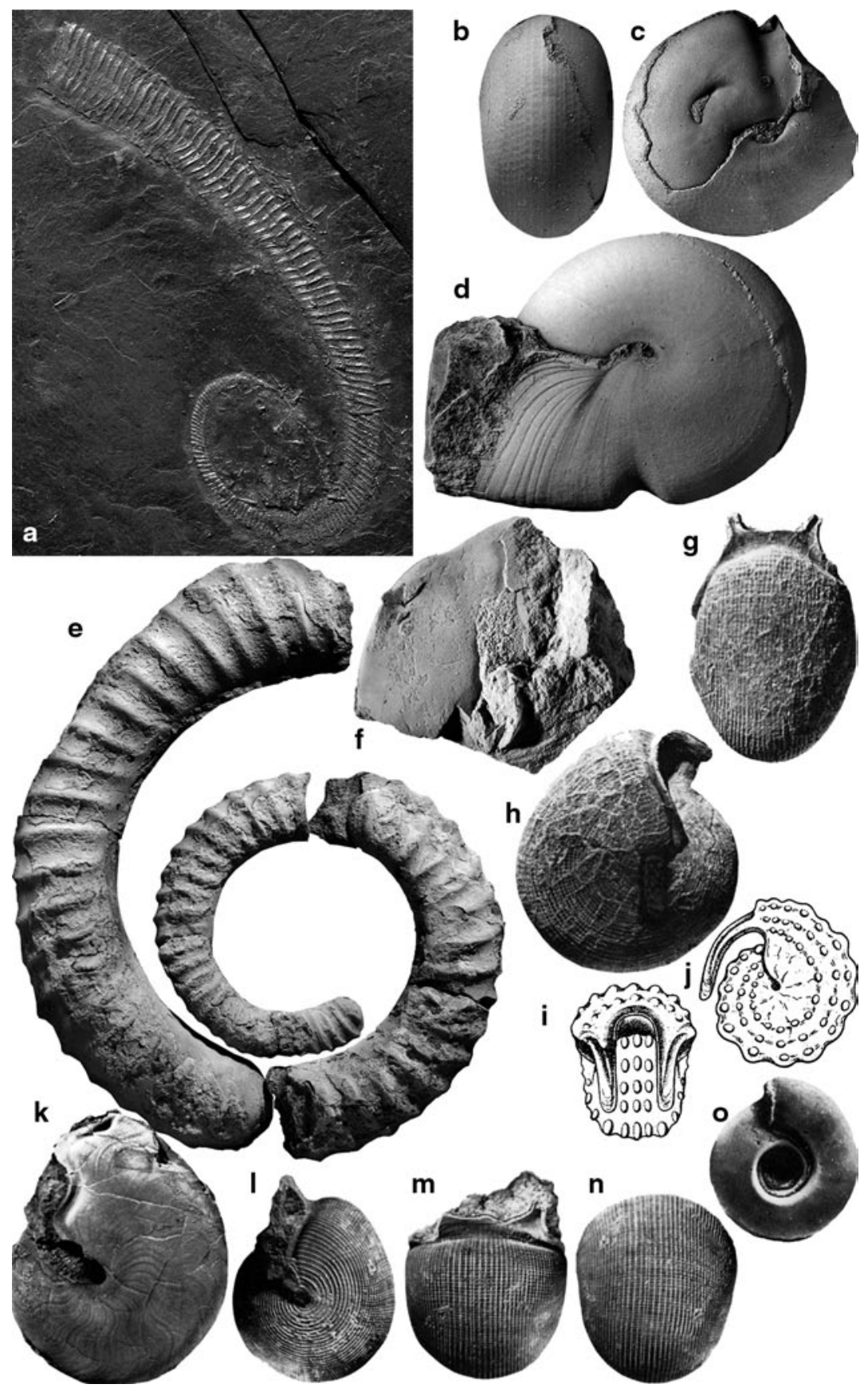

Fig. 7.5 Paleozoic mature modifications. a Metabactrites fuchsi, PWL2010/5251-LS, middle Kaub Formation, Hunsrück, Bundenbach, from De Baets et al. (2013b), dm $80 \mathrm{~mm}$. Note the changes in coiling and ribbing. b-d Prolobites aktubensis, col. Ademmer, Kattensiepen, Germany, 
Table 7.3 Mature modifications in Permian ammonoids. (modified after Davis et al. 1996)

\begin{tabular}{|c|c|c|c|c|c|c|c|c|c|}
\hline 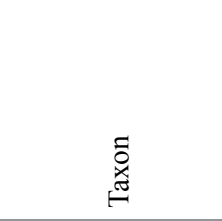 & $\stackrel{0}{\Xi}$ & 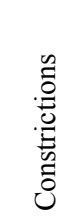 & 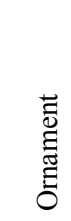 & 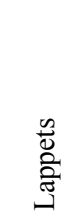 & 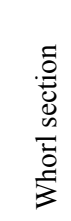 & 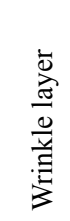 & 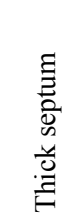 & 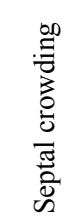 & 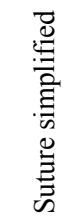 \\
\hline \multicolumn{10}{|l|}{ Adrianitidae } \\
\hline Adrianites & $\bullet$ & $\bullet$ & & $\bullet$ & $\bullet$ & $\bullet$ & & & \\
\hline Crimites & $\bullet$ & $\bullet$ & & & $\bullet$ & & & & \\
\hline Epadrianites & $\bullet$ & $\bullet$ & & & & & & & \\
\hline Hoffmannia & $\bullet$ & $\bullet$ & $\bullet$ & & $\bullet$ & & & & \\
\hline Neocrimites & $\bullet$ & $\bullet$ & $\bullet$ & $\bullet$ & & & & & \\
\hline Palermites & $\bullet$ & $\bullet$ & & $\bullet$ & $\bullet$ & & & & \\
\hline Pseudagathic & $\bullet$ & $\bullet$ & $\bullet$ & & & & & & \\
\hline Sizilites & $\bullet$ & $\bullet$ & $\bullet$ & & $\bullet$ & & & & \\
\hline Texoceras & $\bullet$ & $\bullet$ & & & & $\bullet$ & & & $\bullet$ \\
\hline \multicolumn{10}{|l|}{ Cyclolobidae } \\
\hline Cyclolobus & $\bullet$ & $\bullet$ & & $\bullet$ & $\bullet$ & & & & \\
\hline Mexicoceras & $\bullet$ & $\bullet$ & & & $\bullet$ & & $\bullet$ & & $\bullet$ \\
\hline Waagenoceras & $\bullet$ & $\bullet$ & & & $\bullet$ & $\bullet$ & & $\bullet$ & $\bullet$ \\
\hline \multicolumn{10}{|l|}{ Hyattoceratidae } \\
\hline Hyattoceras & $\bullet$ & $\bullet$ & $\bullet$ & & $\bullet$ & & & & \\
\hline \multicolumn{10}{|l|}{ Marathonitidae } \\
\hline Marathonites & $\bullet$ & $\bullet$ & & & $\bullet$ & & & & \\
\hline Pseudovidrioc & & $\bullet$ & $\bullet$ & & $\bullet$ & & & & $\bullet$ \\
\hline \multicolumn{10}{|l|}{ Vidrioceratidae } \\
\hline Peritrochia & & $\bullet$ & & $\bullet$ & & & & & \\
\hline Stacheoceras & $\bullet$ & $\bullet$ & & $\bullet$ & $\bullet$ & & & & \\
\hline \multicolumn{10}{|l|}{ Agathiceratidae } \\
\hline Agathiceras & $\bullet$ & $\bullet$ & $\bullet$ & $\bullet$ & $\bullet$ & & & & \\
\hline \multicolumn{10}{|l|}{ Pseudohaloritidae } \\
\hline Elephanticeras & & $\bullet$ & $\bullet$ & $\bullet$ & & & & & \\
\hline Sangzhites & $\bullet$ & $\bullet$ & $\bullet$ & $\bullet$ & $\bullet$ & & & & \\
\hline Shangraoceras & $\bullet$ & $\bullet$ & & $\bullet$ & $\bullet$ & & & & \\
\hline
\end{tabular}

from Korn and Klug (2002). b, c SMF 34694. lateral and ventral view; note the elliptical constriction (internal shell projection) and the strong subterminal constriction; dm $21 \mathrm{~mm}$. d SMF 34691; note the change in coiling, lirae spacing and the constriction; dm $28 \mathrm{~mm}$. e Erbenoceras advolvens, early Esmian, Tafilalt, Morocco, from De Baets et al. (2013b); dm $156 \mathrm{~mm}$; note the change in coiling. f Fidelites sp., GPIT 1862-133, costatus conodont Zone, Eifelian, Tafilalt, Morocco; with broad terminal constriction, from Klug (2001). g-l Permian ammonoids from Davis et al. (1996). g, h Adrianites sp., lateral and ventral views, GIUA Drawer 55, T328, Maoen Mollo, Timor, Indonesia, dm 26 mm. i, j Elephantoceras sp., Permina, from Zhao and Zheng (1977). k Cyclolobus walkeri, MNHN B 7520, Ankitohazo, Madagascar; dm 93 mm. l-n Adrianites cf. insignis, BMNH C37654, Sosio Limestone, Province of Palermo, Italy; dm $21 \mathrm{~mm}$. o, Wocklumeria sphaeroides, nr. 572, Famennian, Kowala, Poland, from Czarnocki (1989) 


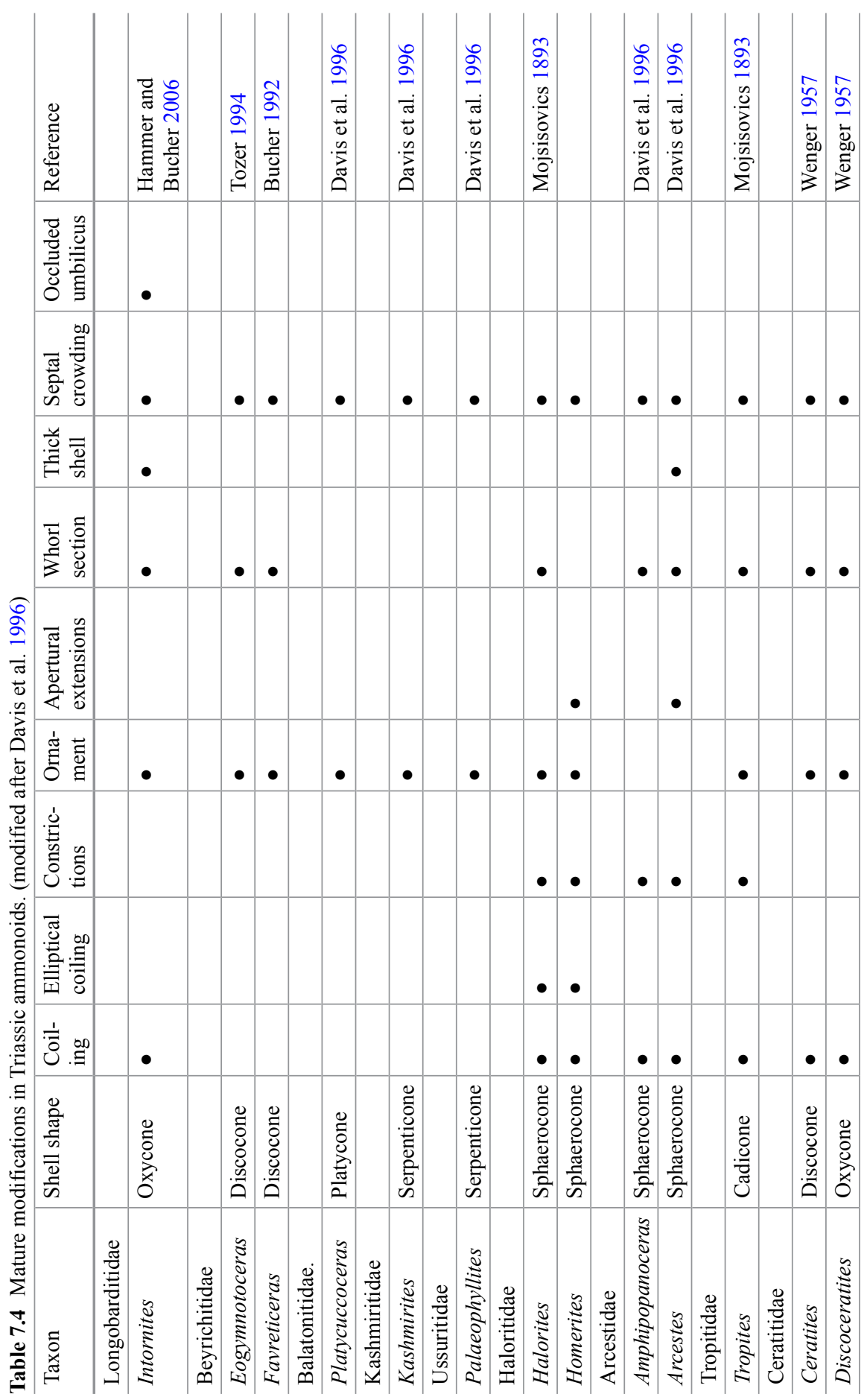




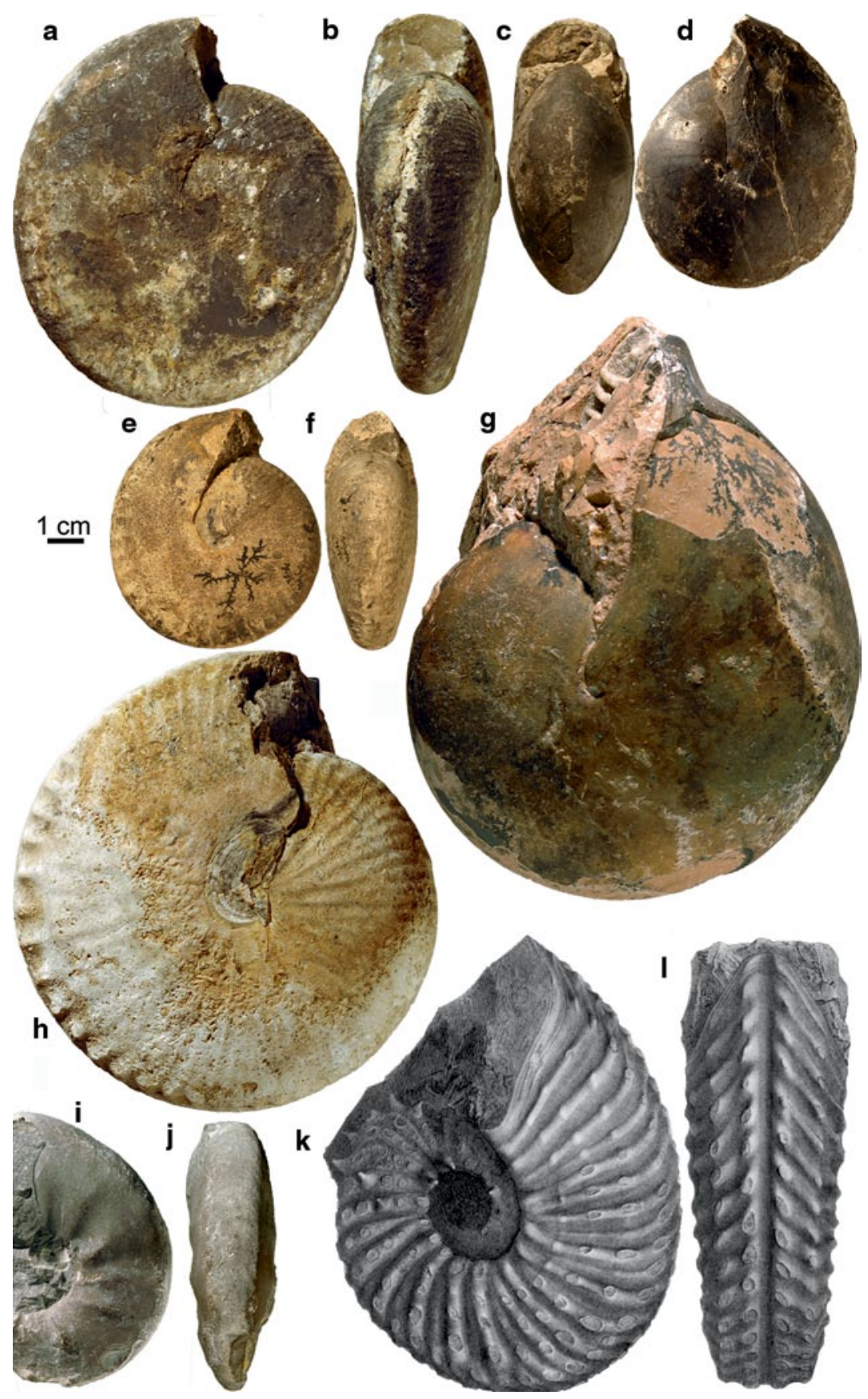

Fig. 7.6 Triassic mature modifications. a, b Halorites macer, PIMUZ 31068, Norian, Bihati?, Timor, Indonesia, dm $103 \mathrm{~mm}$. Note the change in whorl section. c, d Orestites $\mathrm{cf}$. frechi, PIMUZ 31069, Norian, Timor, Indonesia, dm $75 \mathrm{~mm}$. Elliptical coiling and constricted aperture. e, f Lobites ellipticus, PIMUZ SQL43399, Norian, Timor, Indonesia, dm $62 \mathrm{~mm}$. g Arcestes sp., PIMUZ 31067, Norian, Timor, Indonesia, dm 152 mm. h Halorites cf. phaonis, PIMUZ 31066, Norian, Timor, Indonesia, dm $124 \mathrm{~mm}$. i, j Ceratites cf. compressus, MHI 688732, Anisian?, Garnberg, Germany, dm 75 mm. k, I Protrachyceras archelaus, from Mojsisovics (1882), Ladinian, Agordo, Italy, dm $132 \mathrm{~mm}$ 
onstrated cases of dimorphism are exceedingly rare. A first report was published by Müller (1969), who found a questionable egg mass in the shell of Ceratites. This specimen is undoubtedly interesting, but it has neither been proven that the preserved globules are eggs nor that they are part of this ceratitid. It is also questionable because no additional soft parts are preserved in this specimen.

Similarly, the report of Dzik (1990b) of acrochordiceratid antidimorphs is doubtful, because the species of this family have been shown to be highly variable (Monnet et al. 2010). By contrast, the account of dimorphism in Middle Triassic Ceratites by Urlichs (2009) appears to represent one of the first profound accounts of Triassic dimorphism. He collected adult specimens and measured their sizes in populations in combination with morphometric data from juvenile to adult whorls. Thereby, he could show that the antidimorph's juvenile whorls are quite similar and they begin to diverge morphologically late in ontogeny, with clearly separated adult sizes and conch parameters. Probably, many more cases of dimorphism will be detected among Triassic ammonoids when well-preserved materials are carefully analyzed for this aspect.

\subsubsection{Jurassic Dimorphism}

Jurassic ammonoids probably contain some of the most convincing and most impressive, as well as famous, examples of sexual dimorphism (Table 7.5, Fig. 7.7). For example, Makowski's (1962) kosmoceratids became the icon of the journal Acta Palaeontologica Polonica and the impressive combination of extreme size difference, as well as the exotically modified aperture in the dimorphic pair Phlycticeras and Oecoptychius made them well-known among collectors (Fig. 7.8, 7.9).

Several excellent monographs on Jurassic dimorphism are readily available (Makowski 1962; Callomon 1963, 1981; Tintant 1963; Westermann 1964a, b; Elmi 1967; Davis et al. 1996). It is thus not necessary to repeat all their results. At this occasion, however, we want to summarize the categories (Fig. 7.10), which were introduced by Davis et al. (1996):

Category A: Sexual dimorphism has been shown convincingly, applying the criteria of different adult morphologies, close phylogenetic relationship reflected in their early ontogenies, shared geographic as well as stratigraphic occurrences and shared habitats.

Category B: Davis et al. (1996) grouped forms with dubious sexual dimorphism here. In many of the species included in this category, their phylogenetic relationship may be unclear, geographic ranges may differ, and preadult ontogenetic stages are either poorly known, do not match perfectly, or lack diagnostic characters (Ziegler 1974, 1987).

Category C: In this category, species are included that either appear as monomorphic (i.e., minute or no morphological differences in the shells of the sexes) or where the preservation or other factors make the assignment to an antidimorphic pair impossible. Davis et al. (1996) included several genera with strong apertural modifications such as Gemmellaroceras and Cymbites. 


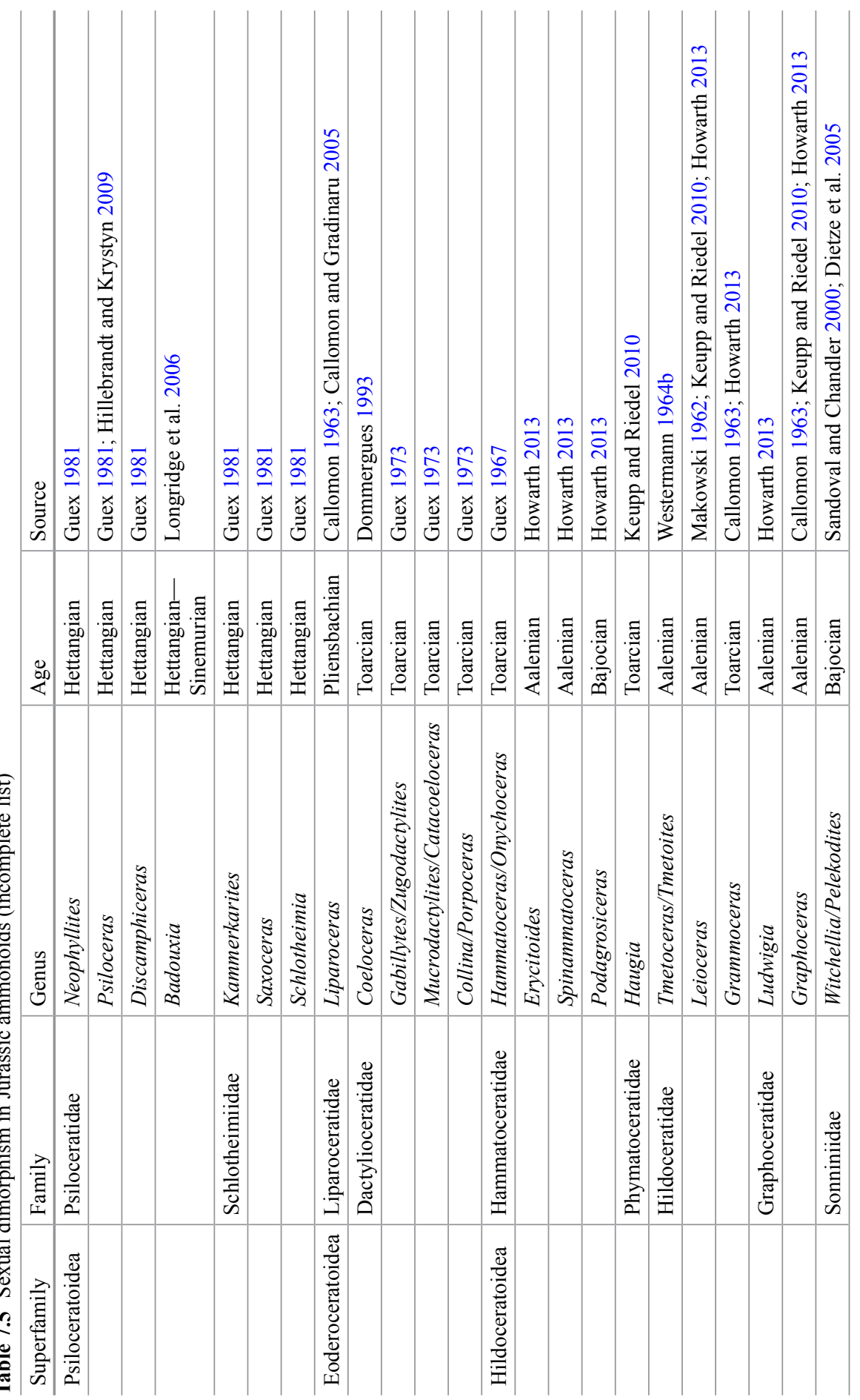



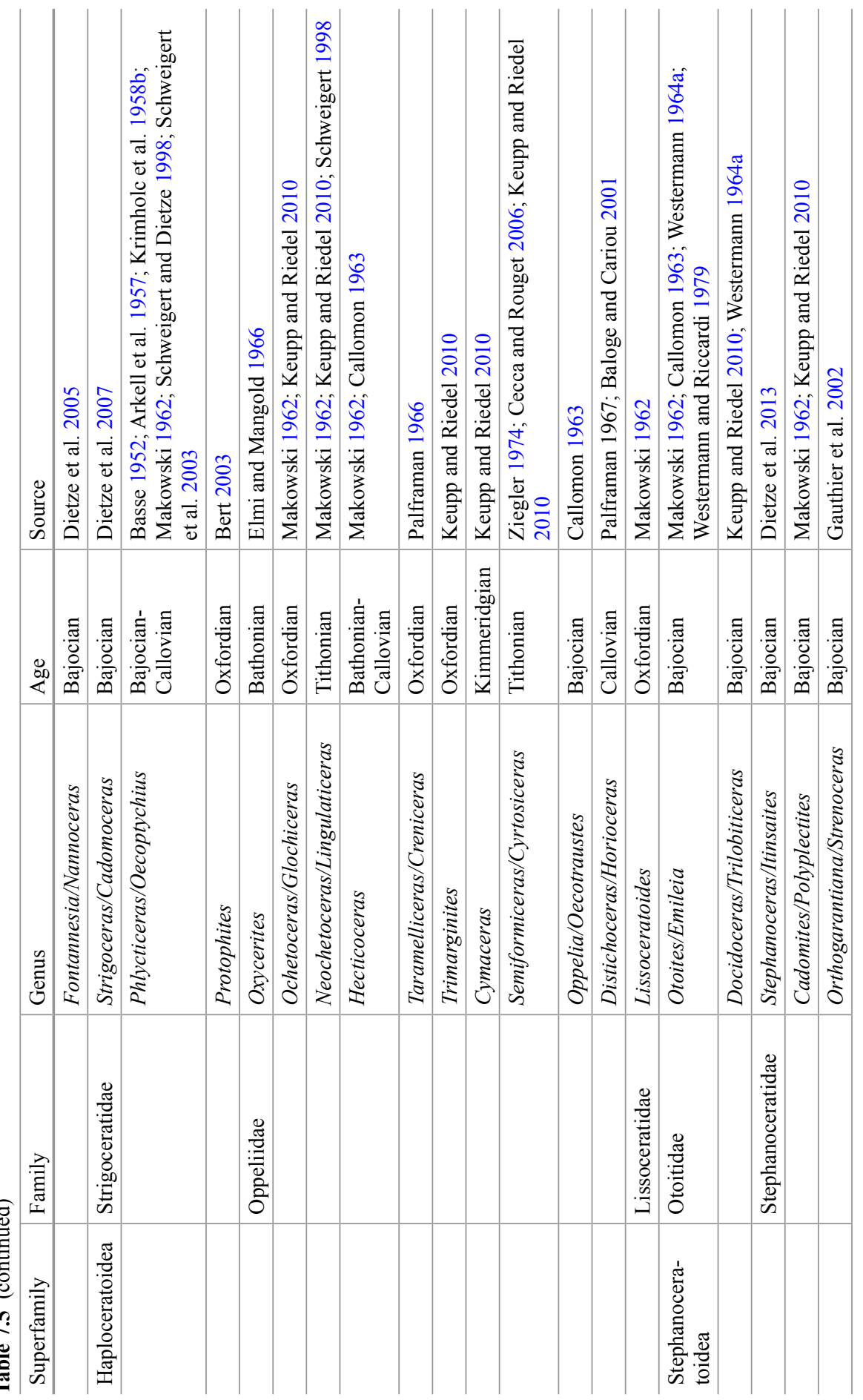


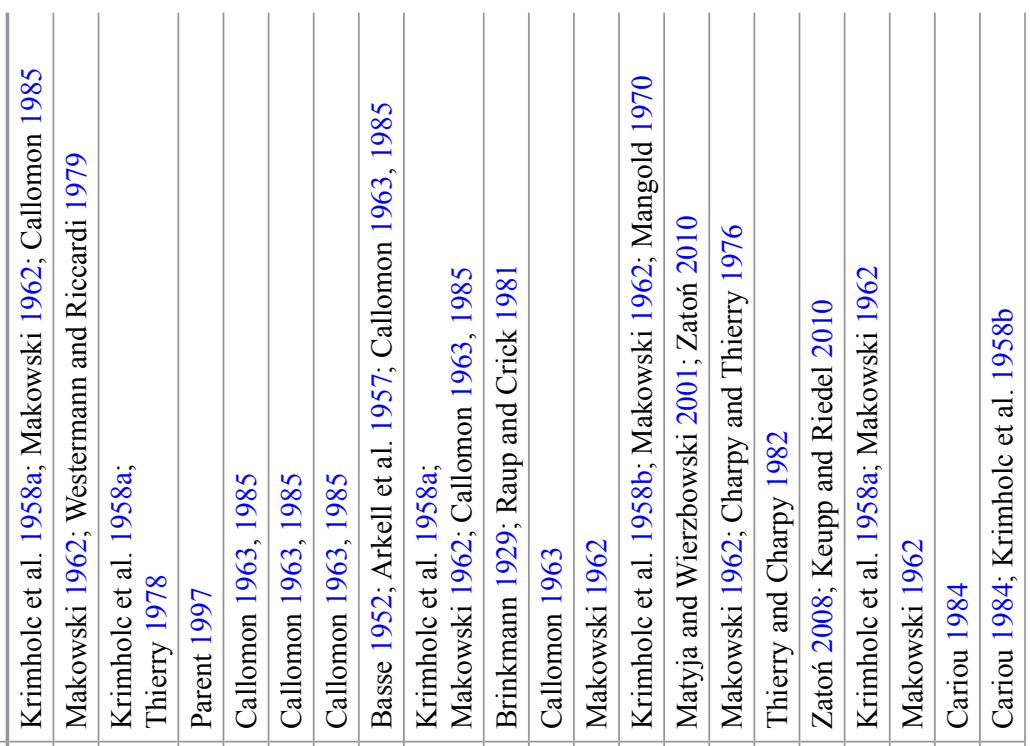

\section{.ज़ .

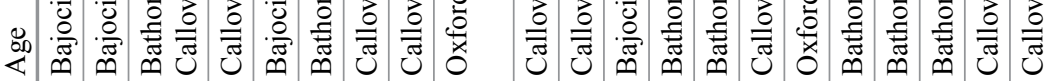

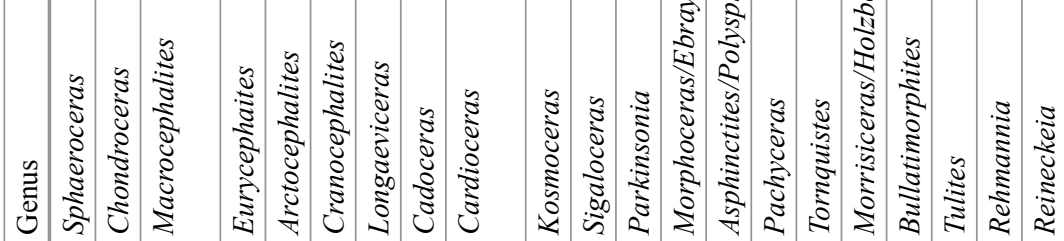

\begin{tabular}{|c|c|c|c|c|c|c|c|}
\hline ح) & 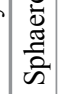 & Uే: & $\begin{array}{l}\tilde{0} \\
\text { : } \\
0 \\
0\end{array}$ & 苛 & 苋 & 总 & \\
\hline 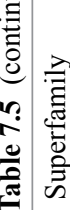 & & & & 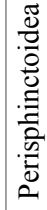 & & & \\
\hline
\end{tabular}




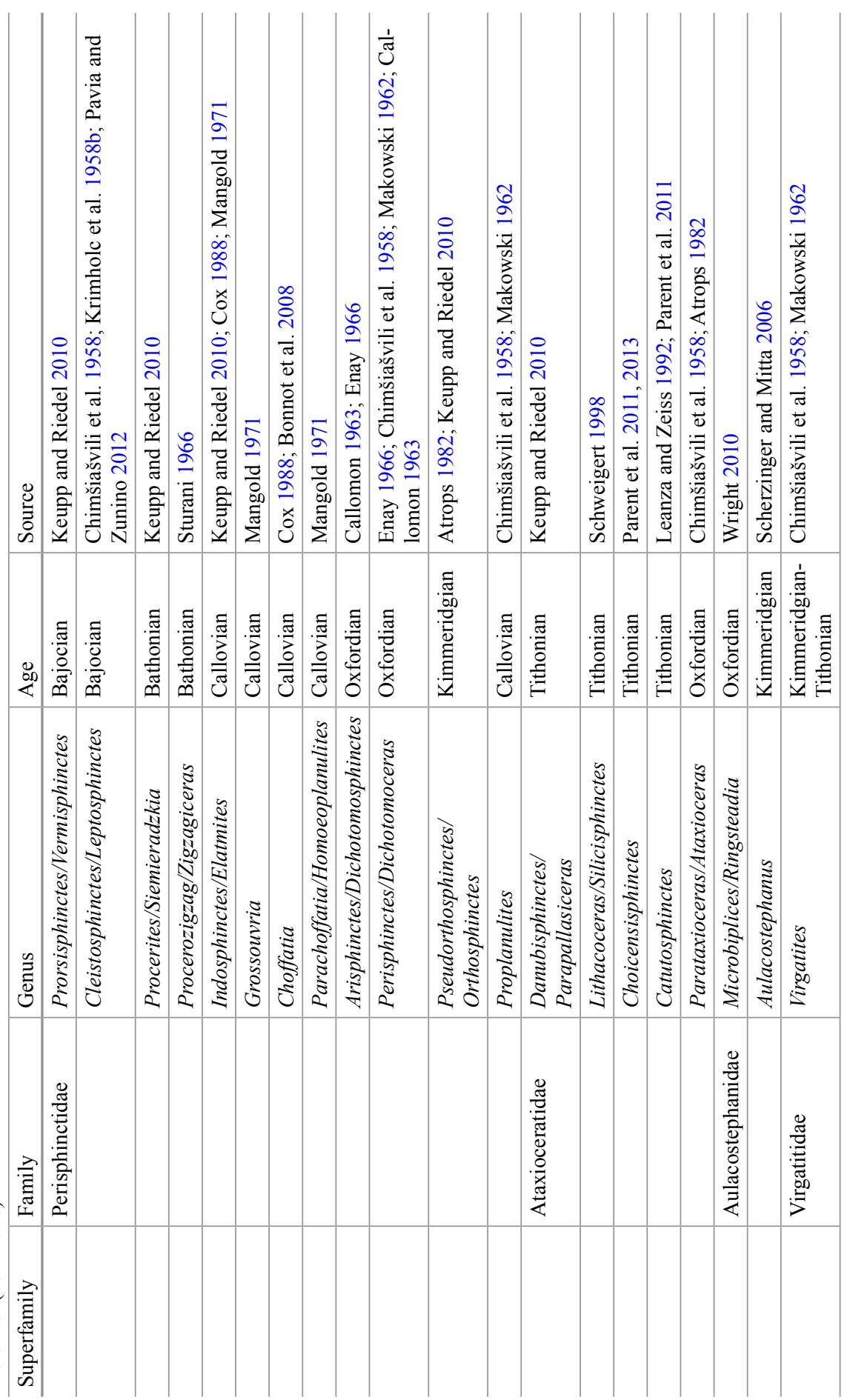




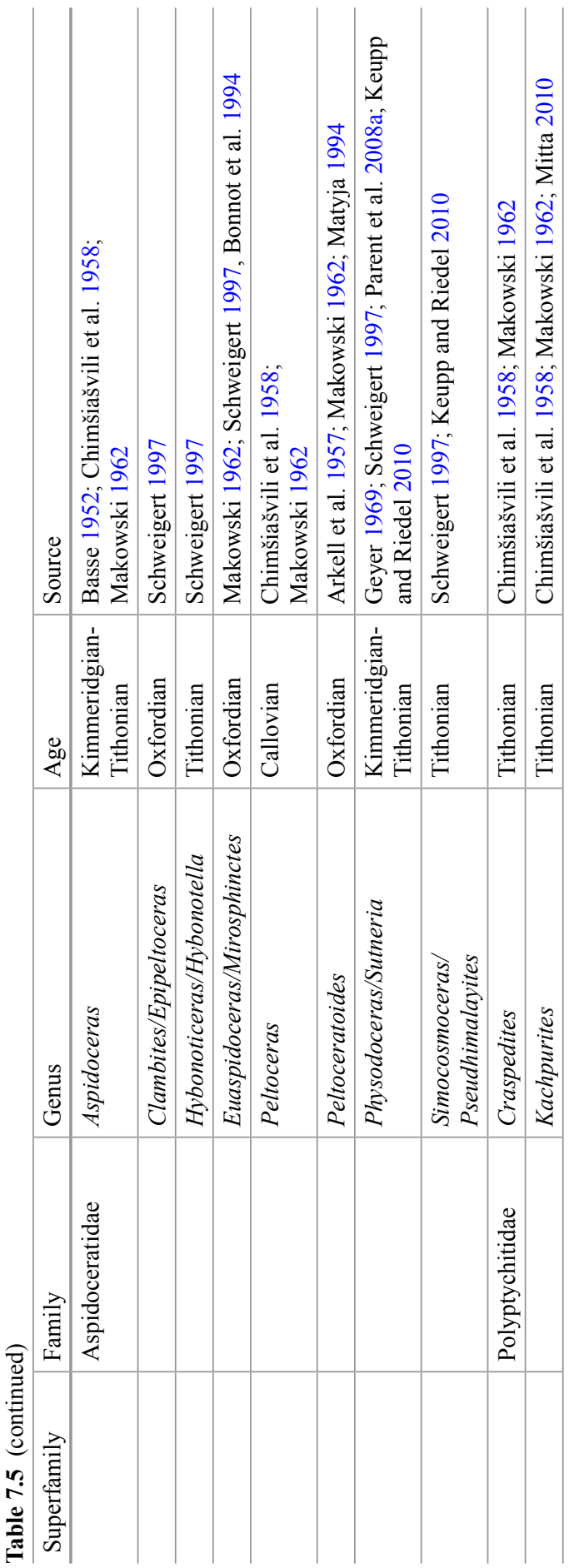




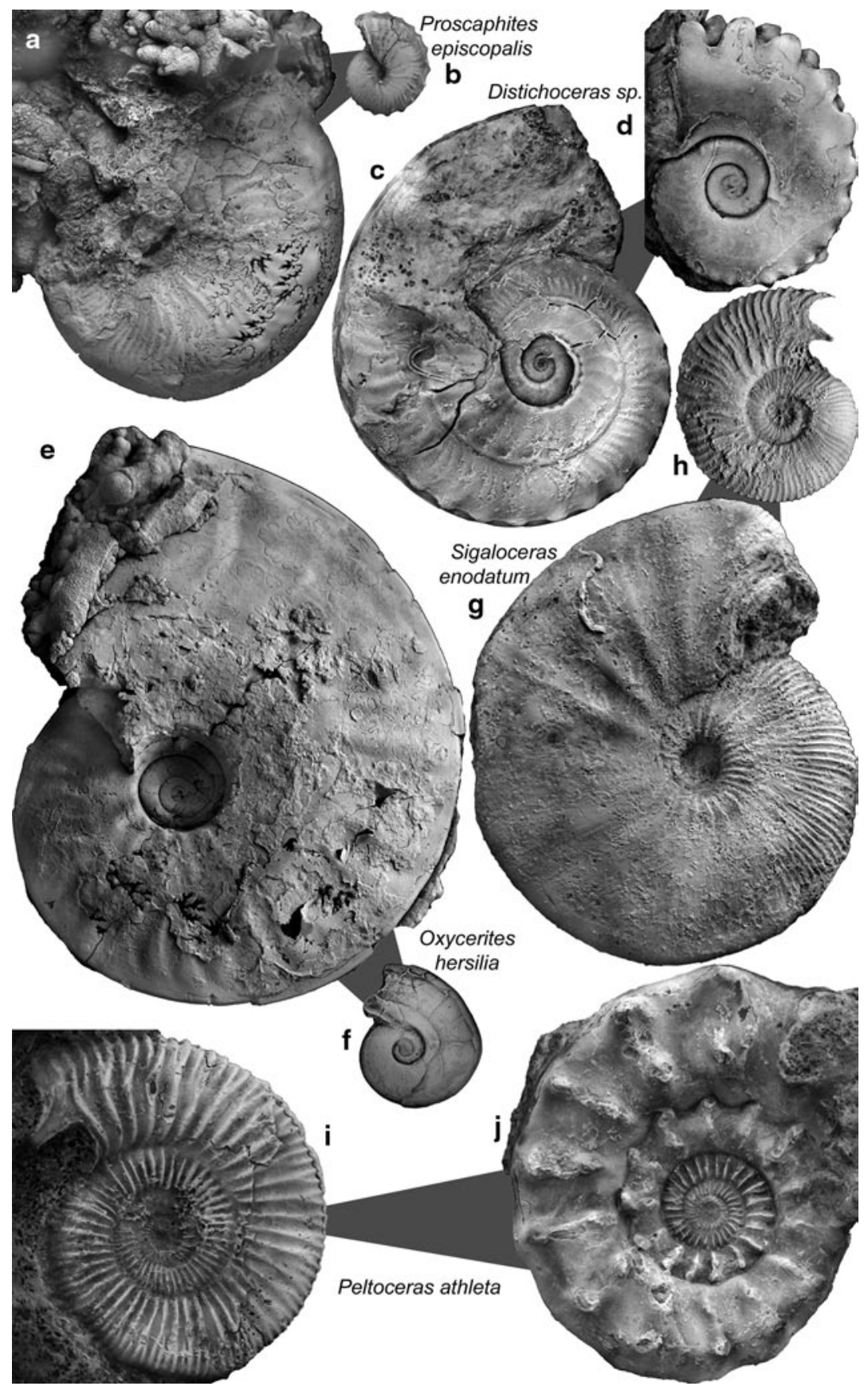

Fig. 7.7 Jurassic antidimorphs. Examples from the Jurassic of Switzerland. The grey triangles connect the antidimorphs, with the narrow end at the microconch. This is an example, how antidimorphic pairs could be given one species name 
Fig. 7.8 Adult specimens of the antidimorphic couple Oecoptychius refractus (Reinecke 1818) (top left; microconch) and Phlycticeras pustulatum (Reinecke 118) (bottom, macroconch). Herznach-Member, Callovian, Swiss Jura Mountains. Note the morphologic and size difference

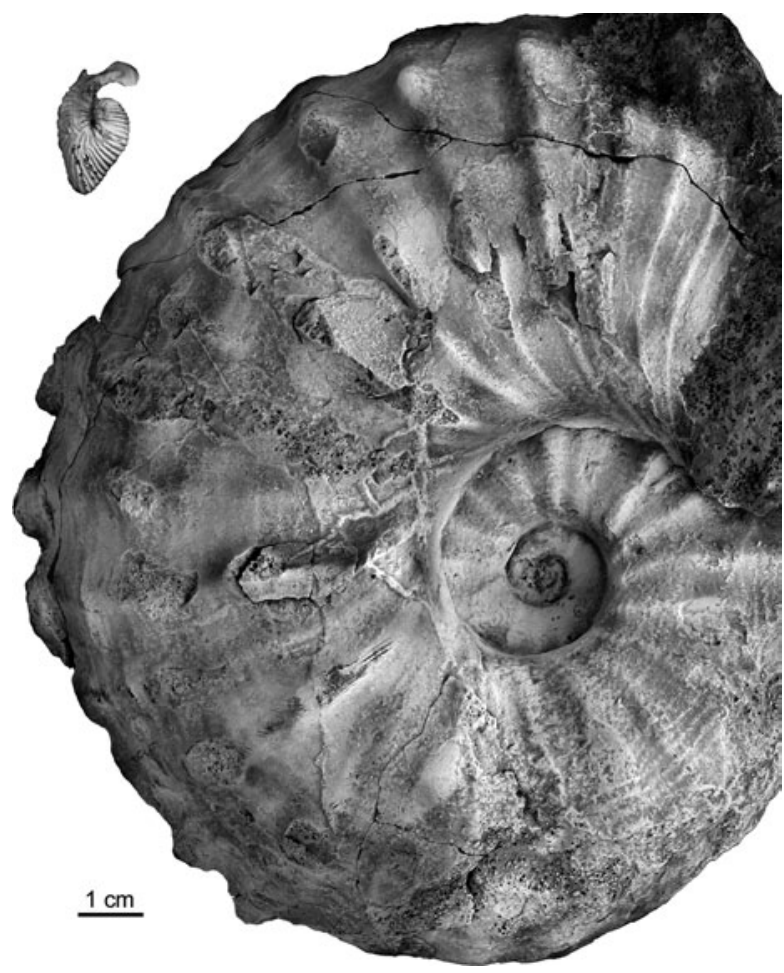

Category D: Nonsexual dimorphism and polymorphism is contained here. Such polymorphic structures have been shown by various authors (Marchand 1976; Charpy and Thierry 1976; Tintant 1976; Thierry 1978; Contini et al. 1984). According to Davis et al. (1996), this variation has nothing to do with sexual dimorphism. The problem here could be the multitude of factors controlling shape and size of antidimorphs. As discussed above, polymorphism may be caused by a variety of processes such as ecological factors (phenotypic plasticity), hormonal processes, and potentially by diseases and parasites. All these factors contribute to intraspecific variability that may have affected microconchs and macroconchs in different ways. Therefore, some of the cases included in Category D may actually represent blurred cases of sexual dimorphism.

Taking the seeming absence of dimorphism or at least its weak expression in the Triassic into account, it is remarkable how common sexual dimorphism already was in the Early Jurassic (Callomon 1963; Lehmann 1966; Guex 1967, 1968, 1973, 1981; Howarth 2013). Depending on the opinion of authors that focused on Jurassic dimorphism, i.e. which case of dimorphism to include or exclude in sexual dimorphism, the abundance of dimorphism became high to very high in the Middle to Late Jurassic (e.g. Ziegler 1974, 1987; Parent 1997; Schweigert 1997; Schweigert and Dietze 1998, Schweigert et al. 2003, 2007; Matyja and Wierzbowski 2001; Parent et al. 2008a, b, 2009; Zatoń 2008, 2010; Keupp and Riedel 2010; Bardhan et al. 
Fig. 7.9 Model of an antidimorphic pair of the Middle Jurassic Phlycticeras/ Oecoptychius by B. Scheffold (Zurich). Note that Oecoptychius might have used a modified arm to transmit a spermatophore. Naturally, many aspects of this reconstruction are based on speculations

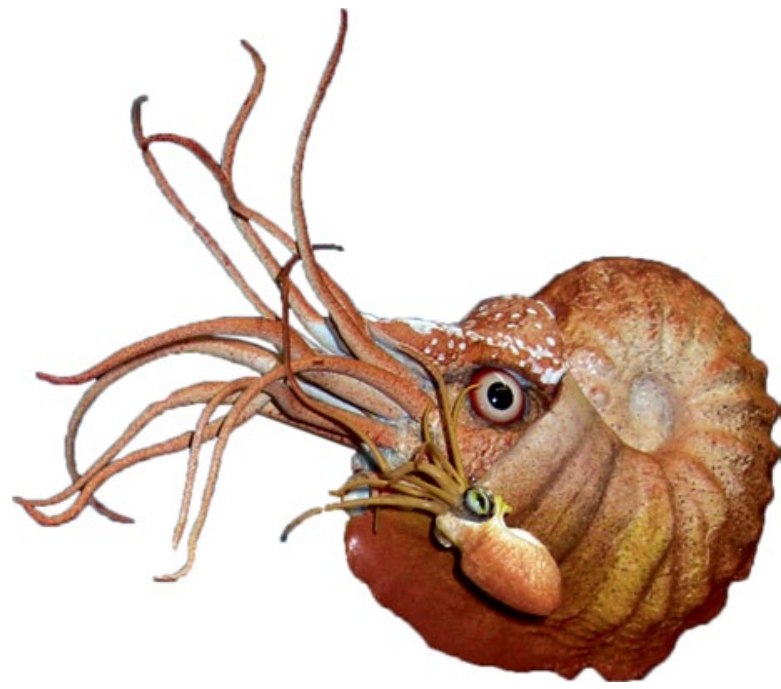

2012). The great success of this reproductive strategy probably originated partially in the fact that many Middle and Late Jurassic ammonoids phylogenetically root in the Hildoceratoidea (Donovan et al. 1981; Davis et al. 1996), which gave rise to many of the younger clades except for the lytoceratids and phylloceratids, which are not known to have produced clear cases of dimorphism (Fig. 7.11), except few cases such as Juraphyllites studied by Cope (1992). This also shows that dimorphism may well be of use as a character for phylogenetic reconstructions. Another factor for the Jurassic success of sexual dimorphism in ammonoids is certainly ecological. The energetic cost of reproduction (the energy that is available for the ovaries and thus eggs) can be significantly reduced when the size of the males, and thus their energy intake, is reduced.

The monophyletic nature of Jurassic sexual dimorphism has another important implication. Genera such as Taramelliceras and Creniceras in the Late Jurassic become more likely to have been antidimorphs (in contrast to the doubts of Davis et al. 1996) because there is a strong phylogenetic component in dimorphism; nevertheless, the situation is complicated by difficulties in taxonomic assignments, and other, similar genera such as Proscaphites, which also show dimorphism. It appears that in the Haploceratoidea, the majority of species produced a pronounced dimorphism. Additionally, the majority of the haploceratoidean microconchs had subcircular to ear-shaped lappets, while those in the stephanoceratids are rather elongate spatulate (Kosmoceras) or subovally elliptical (Normannites).

Interestingly, the peak in well documented sexual dimorphism in conjunction with extreme adult modifications is in the Middle Jurassic, followed by an increasing number of dubious cases in the Callovian to Kimmeridgian and decreasing abundance of mature modifications in the Tithonian (Davis et al. 1996). From the Tithonian onwards, dimorphism continued to exist. 


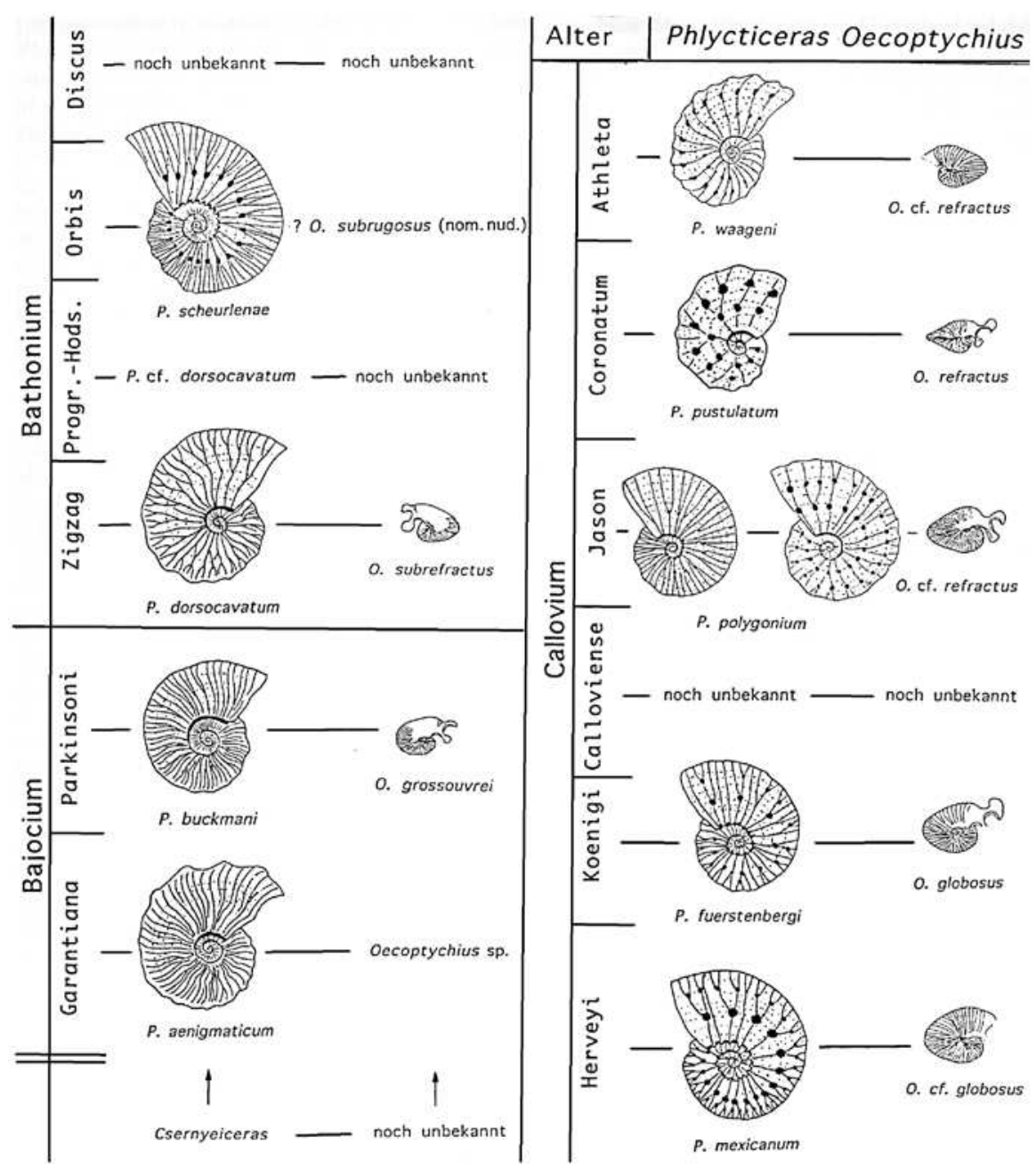

Fig. 7.10 Evolutionary change in the lineage Phlycticeras/Oecoptychius. (slightly modified from Schweigert and Dietze 1998)

\subsubsection{Cretaceous Dimorphism}

As in the Jurassic, each ammonoid clade produced different mature modifications, except for the phylloceratids. The seeming absence of dimorphism in phylloceratids might be due to the scarcity of adult specimens (Davis et al. 1996) and/or to the commonly simple ornament and more or less straight apertures.

In contrast to the phylloceratids, several Cretaceous lytoceratids do display mature modifications (Fig. 7.13). For example, some gaudryceratids changed the whorl cross section and a slight umbilical egression may occur, as well as changes in ornament (Wiedmann 1973; Cooper and Kennedy 1979; for a review of the 
Fig. 7.11 History of dimorphism in Jurassic ammonoids, taking into account the types of species structure, i.e. the predominant type of adults depending on the amount of dimorphic forms (redrawn from Davis et al. 1996). Al microconchs with strong mature modifications (e.g., rostrum, lappets); $A 2$ microconchs with weak mature modifications; $B$ groups that look like sexually dimorphic taxa but lack some features to determine dimorphism; $C 1$ monomorphic, small forms with adult modifications; $C 2$ monomorphic, moderately large to large forms without adult modifications

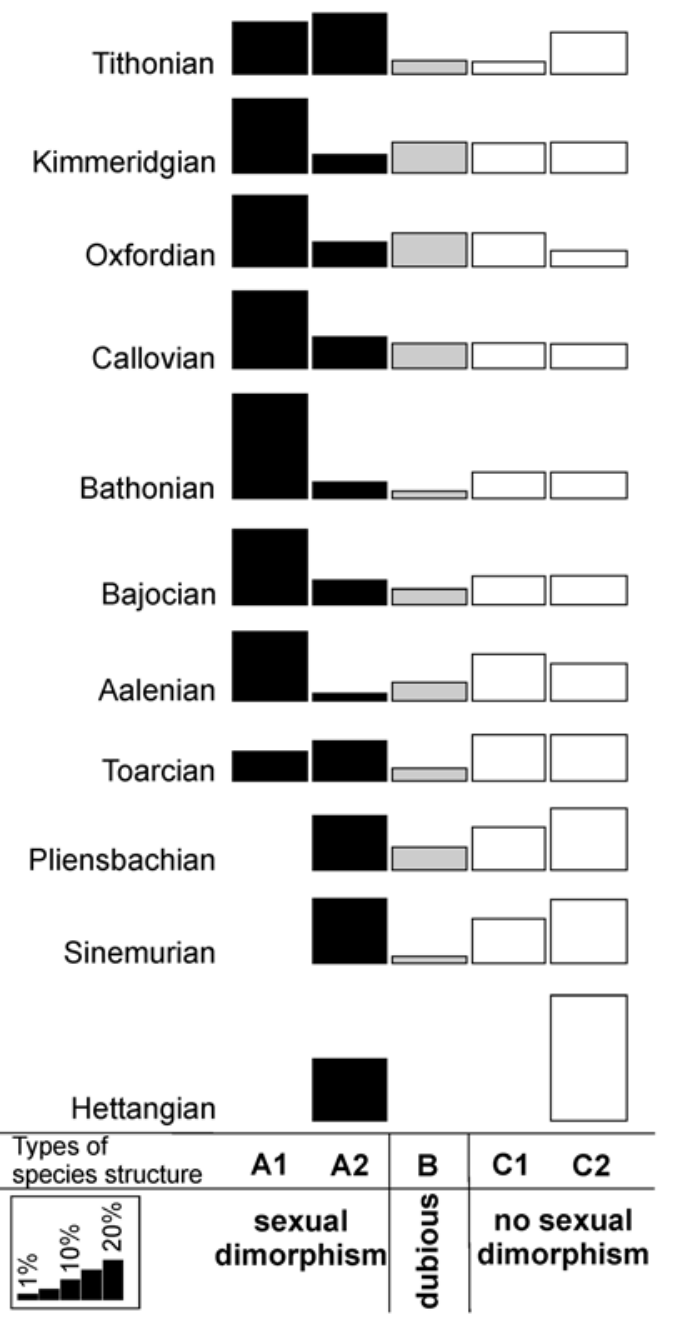

group see Hoffmann 2010). In haploceratoideans such as Aconeceras, the apertural lappets are less distinct than in the Jurassic, but also present, and combined with a short triangular ventral rostrum (Doguzhaeva and Mutvei 1991). Davis et al. (1996) mention an interesting mode of terminal countdown in Menuites, which is remotely reminiscent of the white venter in nautilid shells: in the microconchs of this genus, the ventral tubercles and spines vanish about a demi-whorl behind the terminal aperture (Cobban and Kennedy 1993). The venter and the ventrolateral part stay smooth until shortly behind the terminal aperture, where they re-appear. Hauericeras, by contrast, resembles in its terminal aperture the haploceratoideans (Obata et al. 1978). According to Klinger and Kennedy (1989), the hoplitoidean Placenticeras kaffarium displays a rather strong umbilical egression, which gives it a scaphitoid adult morphology. Additionally, the venter became rounded and the 
ornament changed. The possibly most conspicuous adult modification in the Cretaceous among the regularly coiled ammonites is that of the Albian acanthoceratoidean Mortoniceras, which forms a long ventral spine, which may be directed ventrally (M. equidistans) or even curved posteriorly (M. rostratum), forming almost a complete loop (e.g., Cooper and Kennedy 1979). Additionally, the whorl cross section and ornament changed.

The most famous kinds of mature modifications are undoubtedly those of the Cretaceous heteromorphs of the superfamilies Ancyloceratoidea and Turrilitoidea. A good example is the ancyloceratoidean scaphitids (Fig. 7.13, 7.14), which have a wide geographic distribution and a rather impressive diversity. In most species of this group, a more or less straight shaft with a terminal hook follows the normally planispirally coiled phragmocone (Cobban 1951; Landman 1987). Additionally, the aperture is constricted (e.g., Landman et al. 2012). The degree of uncoiling and the length of the straight shaft in relation to the terminal diameter vary as well as the changes in ornament (e.g., in Hoploscaphites or Scaphites). The microconchs of both Worthoceras and Yezoites carry broad lappets (Fig. 7.13) with strong convex growth lines (Tanabe 1977; Kennedy 1988). In the Santonian Scaphites (Pteroscaphites) coloradensis, the lateral lappets occur in both antidimorphs and have a peculiar hollow spine-like morphology (Kennedy 1988; Landman 1989).

The mature modifications of some Turrilitoidea appear even more unusual. In the baculitids, the adult modifications are usually limited to changes in ornament (stronger ribs on the venter), sometimes a slight dorsal turn of the aperture and dorsal as well as ventral lappets (Kennedy 1988; Cobban and Kennedy 1991c; Klug et al. 2012). The ventral projection or rostrum can be rather long, clearly exceeding the shell diameter. Davis et al. (1996) figured a Baculites in which this projection is very long. They assumed that the rostrum might have attained this long size due to an injury or infection. By contrast, we have seen other specimens with similarly shaped adult apertures, thus indicating that this might be a normal adult aperture of this species (Fig. 7.13).

In many genera, such as Nostoceras, Didymoceras, Allocrioceras or Emericiceras, the terminal demi-whorl is characterized by a U-shaped part (e.g., Stephenson 1941; Kennedy 1988; Cobban and Kennedy 1994a). In most cases, the coiling direction differs more or less strongly from the preceding whorls. Sometimes, the plane of coiling stayed the same (like in the turrlilitoideans Allocrioceras, Emericiceras and Labeceras, and the lytoceratid Macroscaphites), sometimes the plane of coiling changed: in Eubostrychoceras, Hyphantoceras, Nostoceras and Didymoceras, for example, the coiling axis turned for $50-90^{\circ}$. In Didymoceras nebrascense, this change in coiling axis is merely a continuation of a similar change in the preceding whorls; in this species, the coiling axis appears to be coiled in itself (Meek and Hayden 1856). By contrast, the Japanese Pravitoceras might be the only genus in which the coiling axis switches rapidly for $90^{\circ}$. In all these cases, this terminal countdown of heteromorphs (Seilacher and Gunji 1993) is linked with changes in ornament.

The abundance of such a U-shaped terminal demi-whorl raises the question of the selective force behind it. Although the ultimate evidence is lost due to the ex- 


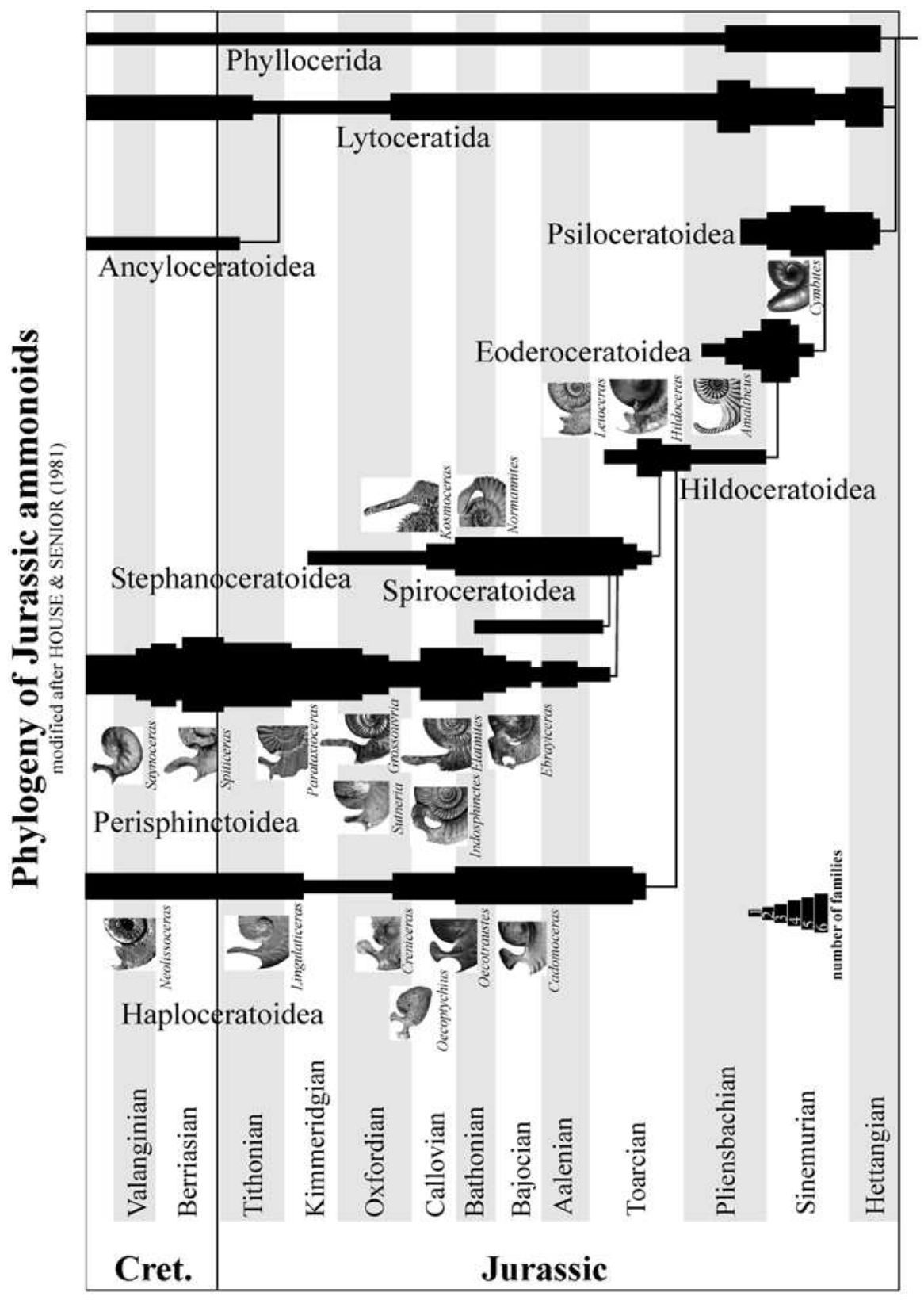

Fig. 7.12 Modified peristomes of adult microconchs of the Jurassic and Early Cretaceous. Note the rather uniform lappets in the haploceratoids, the rather straight lappets in the perisphinctoids, and the disparity in the lappets among the stephanoceratoids. Image sources: V. Schlamp (Elatmites, Paralingulaticeras, Parataxioceras lothari), J.-S. David (Cadomoceras cadomense; Cymbites laevigatus; Ebrayiceras pseudoanceps; Hildoceras lusitanicum; Morrisiceras schwandorfense; Oecotraustes bomfordi); D. Bert (Kosmoceras phaeinum); H. Chatelier (Saynoceras); Quenstedt (1885: Amaltheus margaritatus; Leioceras opalinum); R. Roth (Creniceras crenatum; Sutneria platynota); P. Branger (Indosphinctes; Normannites orbignyi); Dietl (2013: Grossouvria). Djanelidzé (1922: Spiticeras kiliani, modified or reduced); Atrops and Reboulet (1995: Neolissoceras grasianum, modified or reduced); Ernst and Klug (2011: Oecoptychius refractus) 


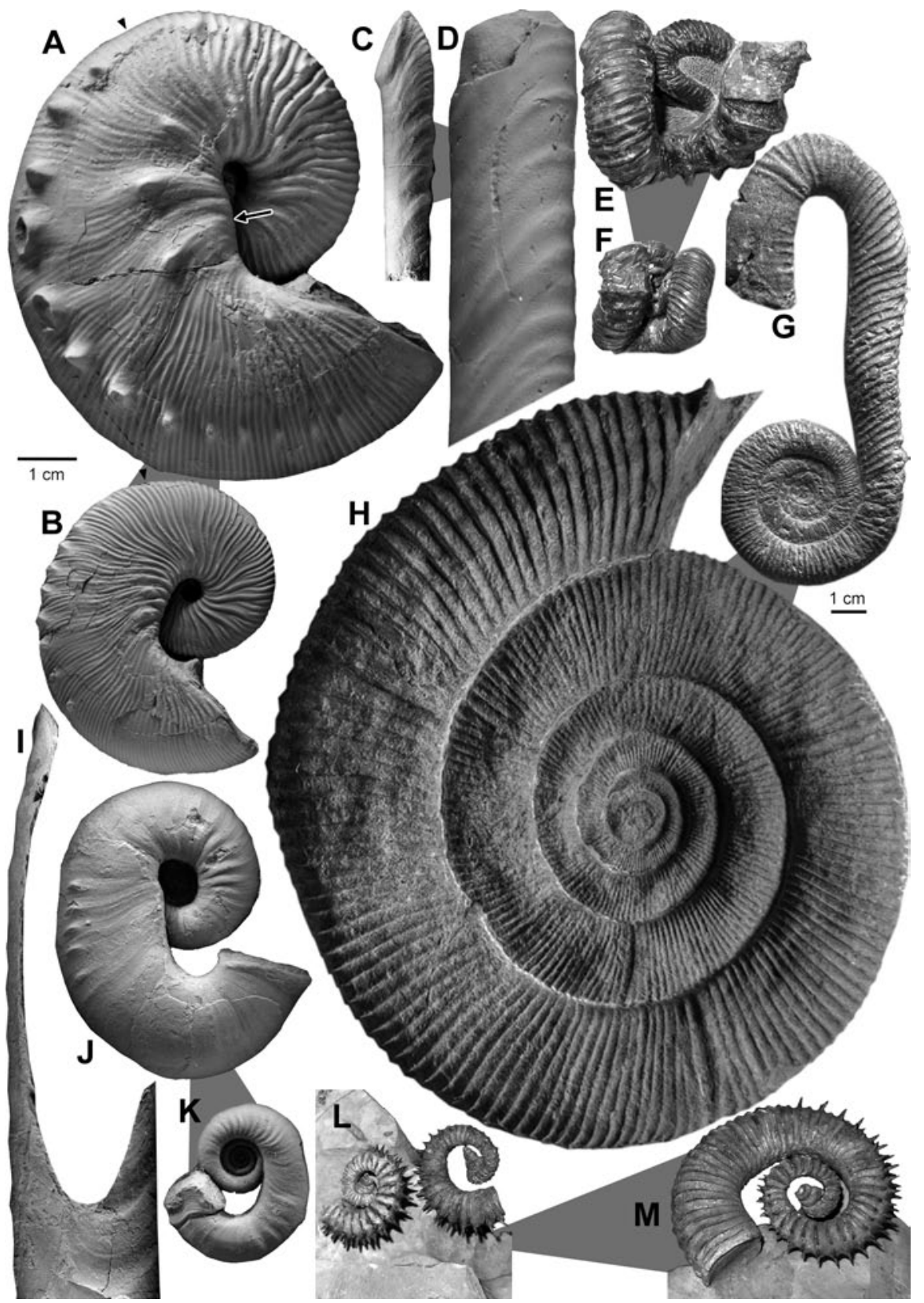

Fig. 7.13 Cretaceous antidimorphic pairs. a, b Hoploscaphites brevis, Pierre Shale, South Dakota. Last septum is marked by a triangle. A, Macroconch, USNM 367, lateral view, dm $90 \mathrm{~mm}$. Note the bulge along the umbilical margin (arrow). B, Microconch, lateral view, AMNH 58514, dm $55 \mathrm{~mm}$. c, d Sciponoceras gracile, Cenomanian, Texas. C, microconch, USNM 411539, wh $9 \mathrm{~mm}$. D, Macroconch (USNM 411537, wh $17 \mathrm{~mm}$. The antidimorphs differ mainly in size. e, f Nippo- 
tinction of the Ammonoidea, one line of reasoning shall be mentioned here: it is conceivable that this upward turn of the terminal aperture enabled the heteromorphs to approach the level of the center of mass with their hyponome, thus significantly improving their swimming abilities in a horizontal direction. Such a horizontal alignment of aperture and centre of mass was achieved in most ammonoid clades and apparently there was some selection for that trait (e.g., Korn and Klug 2003; Klug and Korn 2004; Tajika et al. 2014). This might have been of particular importance at the time of mating.

Like the mature modifications, dimorphism has been reported from most Cretaceous superfamilies except for the phylloceratines (Table 7.6; Kennedy and Wright 1985a; Davis et al. 1996). Concerning members of the Desmoceratoidea, sexual dimorphism has been described for Campanian Menuites (Cobban and Kennedy 1993), where the antidimorphs differ strongly in size. Maeda (1993) examined the dimorphism of Campanian Yokoyamaoceras, where the microconch reaches only a third of the diameter of the macroconch (with two whorls less), has a stronger ornament, an aperture with lateral lappets, and a strong ventral projection. For the acanthoceratoidean Metoicoceras from the Cenomanian, Cobban and Kennedy (1991b) described a size difference where the macroconch is more than twice as big as its counterpart (Cobban 1953). Its microconchs are more robust and thus have a stronger ornament. Except for the ornament, which is finer in the last whorl of the microconch, the same applies to Subprionocyclus (Futakami 1990).

Interestingly, albeit controversial in our opinion, one view on dimorphism of the Valanginian ammonite Valanginites nucleus from Wąwał in central Poland was presented by Ploch $(2003,2007)$. Here, the size differences in identically ornamented and identically coiled specimens with purely macroconchiate modification of the terminal part of the shell (prominent lip preceded by a constriction and without lappets) have been used as the only criterion in separating micro- and macroconchs. It is all the more strange as these ammonites are associated with similarly ornamented but much smaller shells having lateral lappets, classified as Saynoceras verrucosum (see Dzik 1990a). Thus, it appears that V.nucleus might represent the macroconch and $S$. verrucosum its antidimorphic microconch (see also Bulot et al. 1990).

In scaphitids (Ancyloceratina), dimorphism is very well known. Morphological differences between the terminal whorl of scaphitid antidimorphs include adult diameter, coiling, ribbing and nodes or spines, septal crowding, and apertural modifications including lateral and/or dorsal lappets. For example, in Hoploscaphites, the more or less straight shaft of the terminal whorl of the macroconch carries a

nites mirabilis, Campanian, Hokkaido, Japan. The antidimorphs differ mainly in size. g, h Macroscaphites yvani, Barremian, Angles, France. g microconch with large terminal hook. h regularly coiled macroconch, G12/336. i microconch with hook, GRY/903b. i mature apertural margin of a microconch (?) of the Santonian Baculites thomi, USGS 21419, Montana, with a short dorsal and a long, ventral rostrum. j, k Yezoites puerculus, Turonian, Hokkaido, Japan. j Macroconch, AMNH 45280. k microconch, AMNH 45281, note the lateral lappets and the absence of nodes. I, m Imerites dichotomum, Barremian, Alpes de Haute Provence, France. 1 notice that one of the microconchs is sinistral and the other dextral; dm $45 \mathrm{~mm}$. m macroconch, $\mathrm{dm} 75 \mathrm{~mm}$. (Images: a-d, i-k (N. Landman). e, f, l, m (W. Grulke). h, i (D. Bert)) 


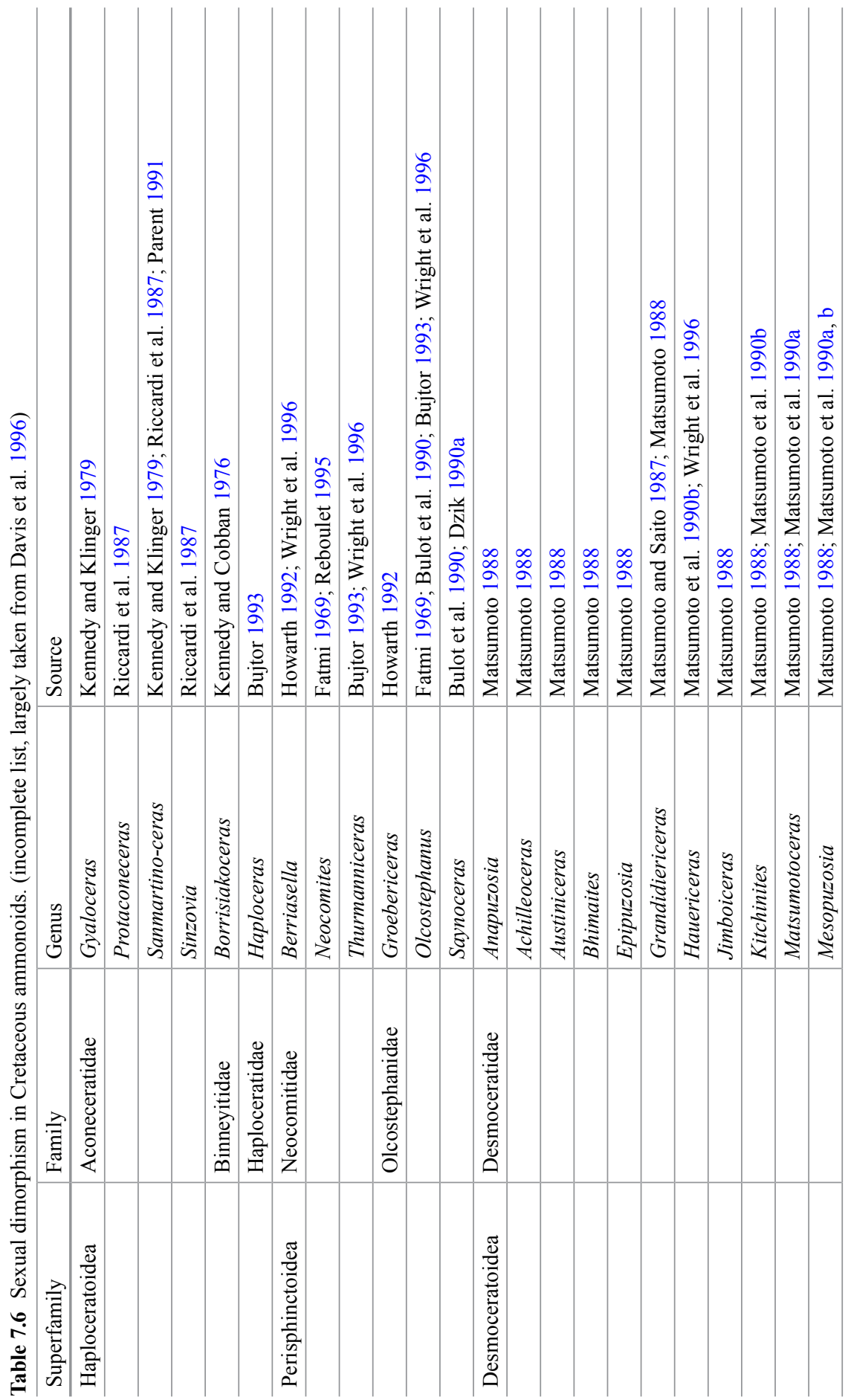




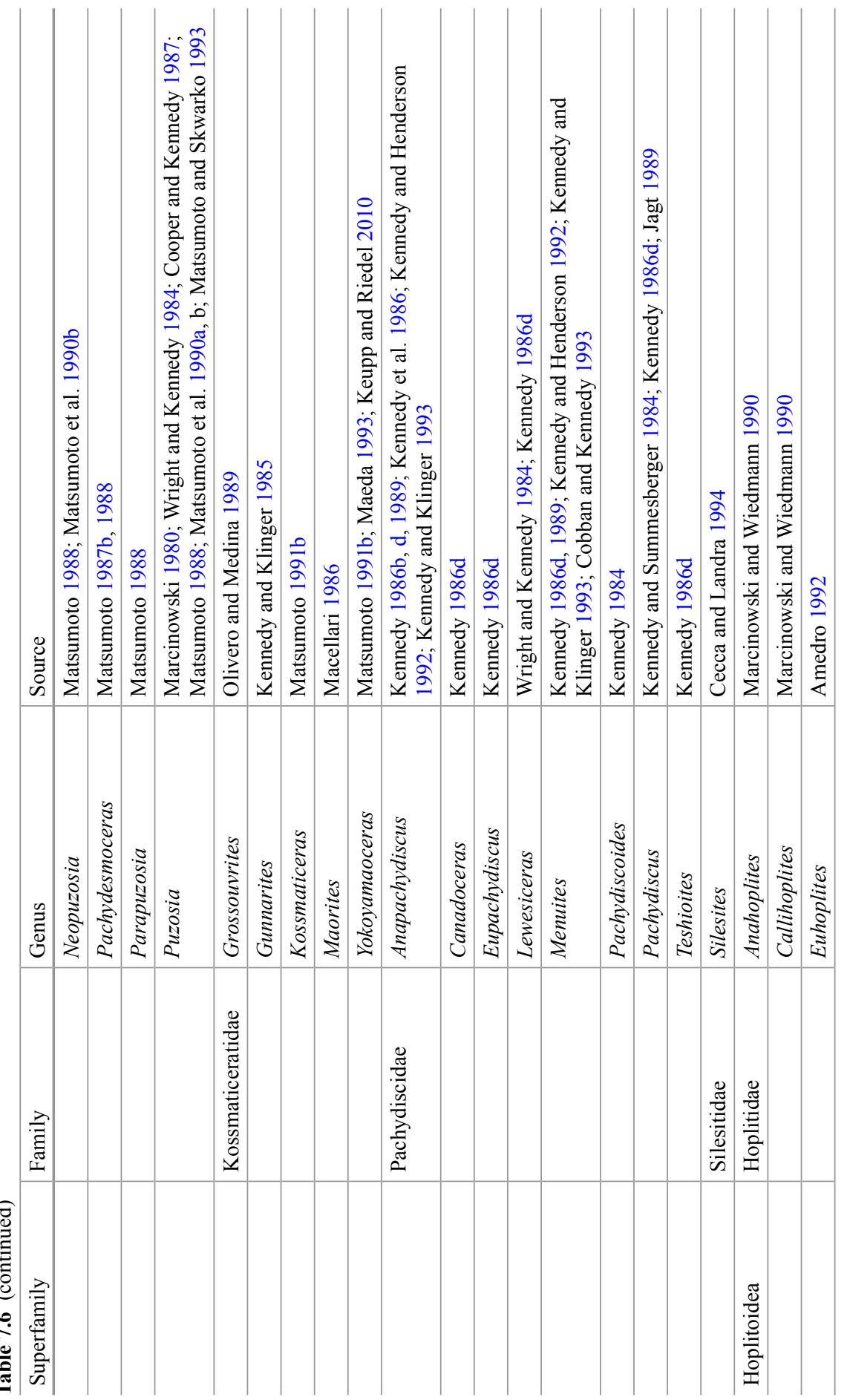




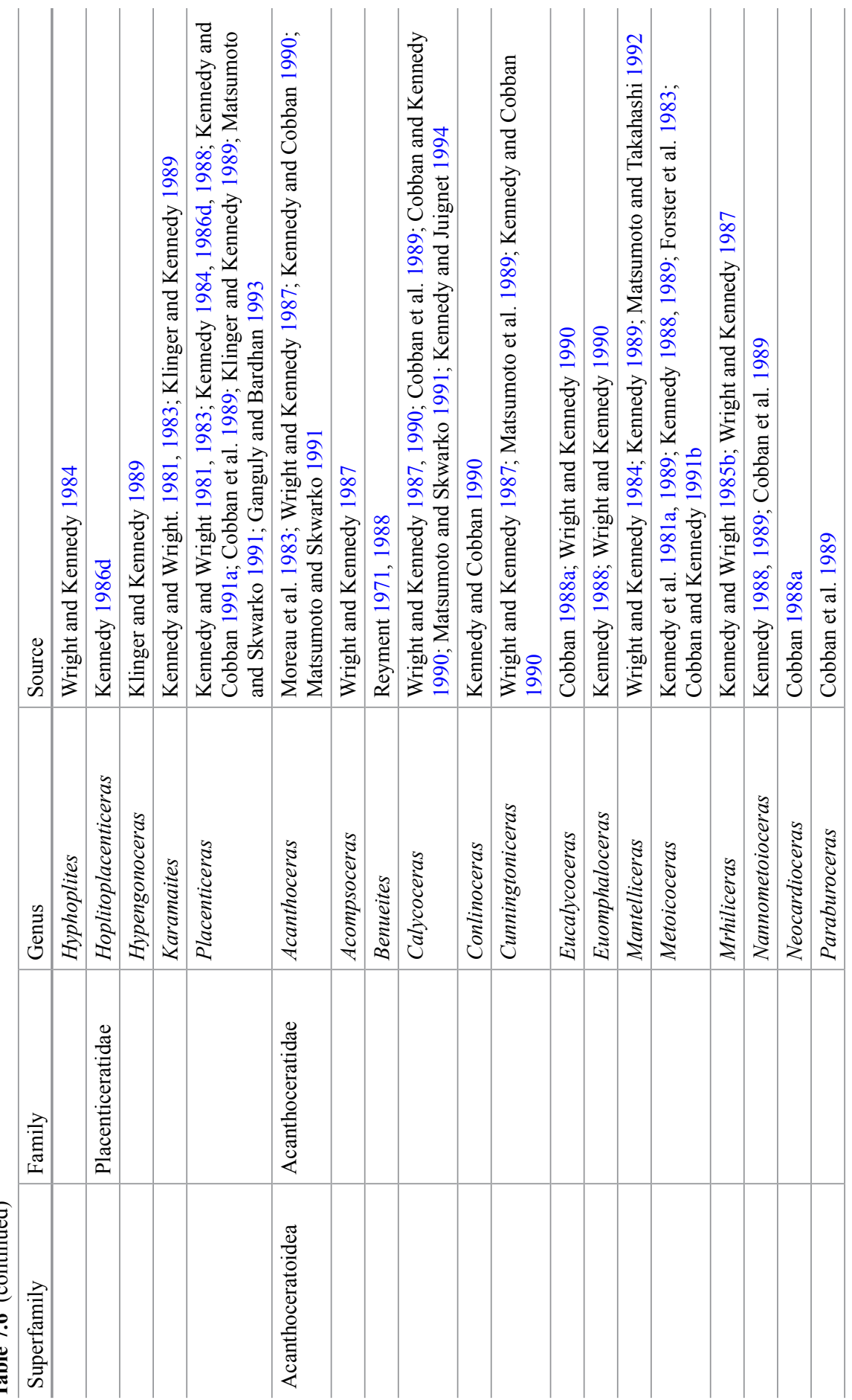



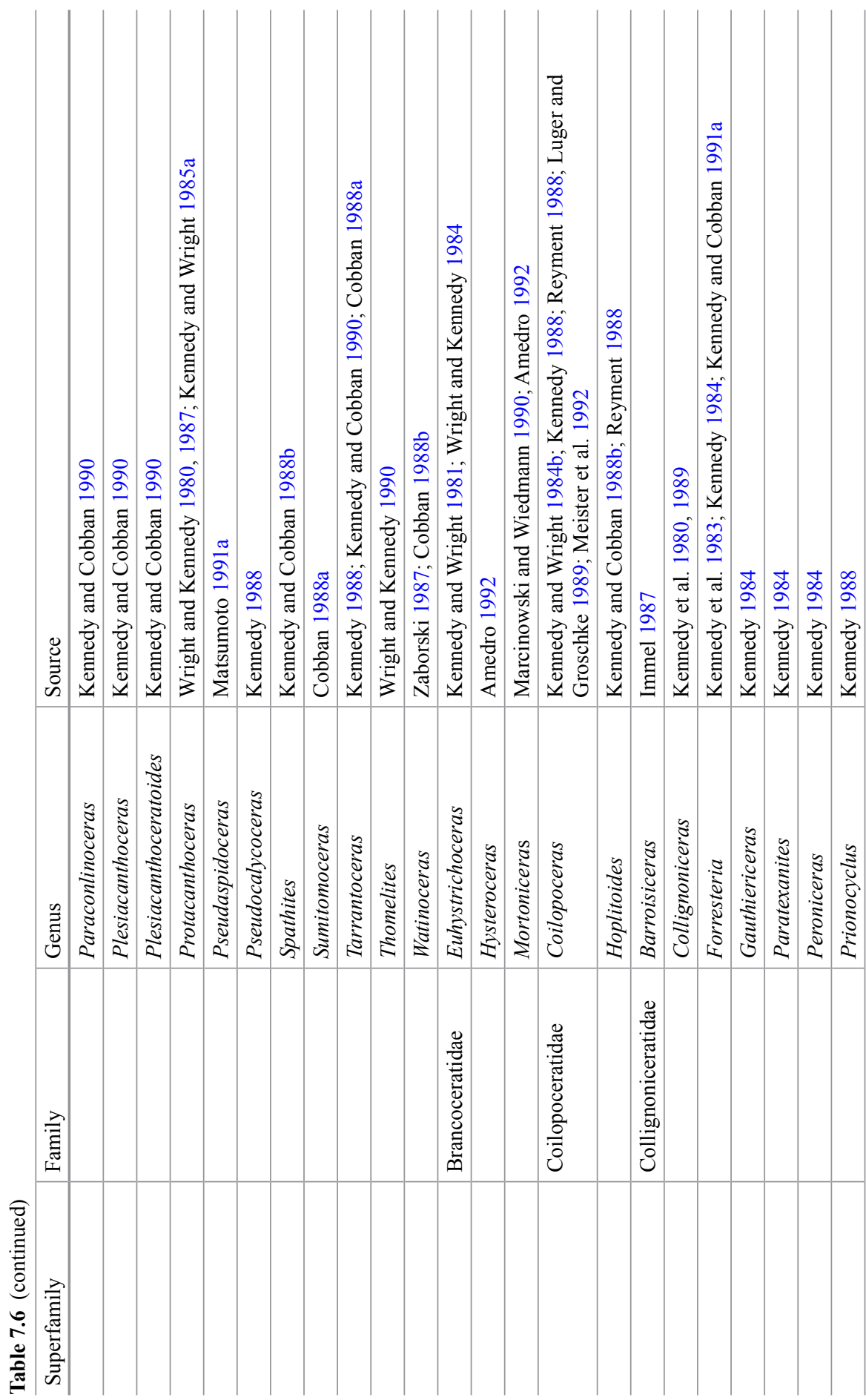


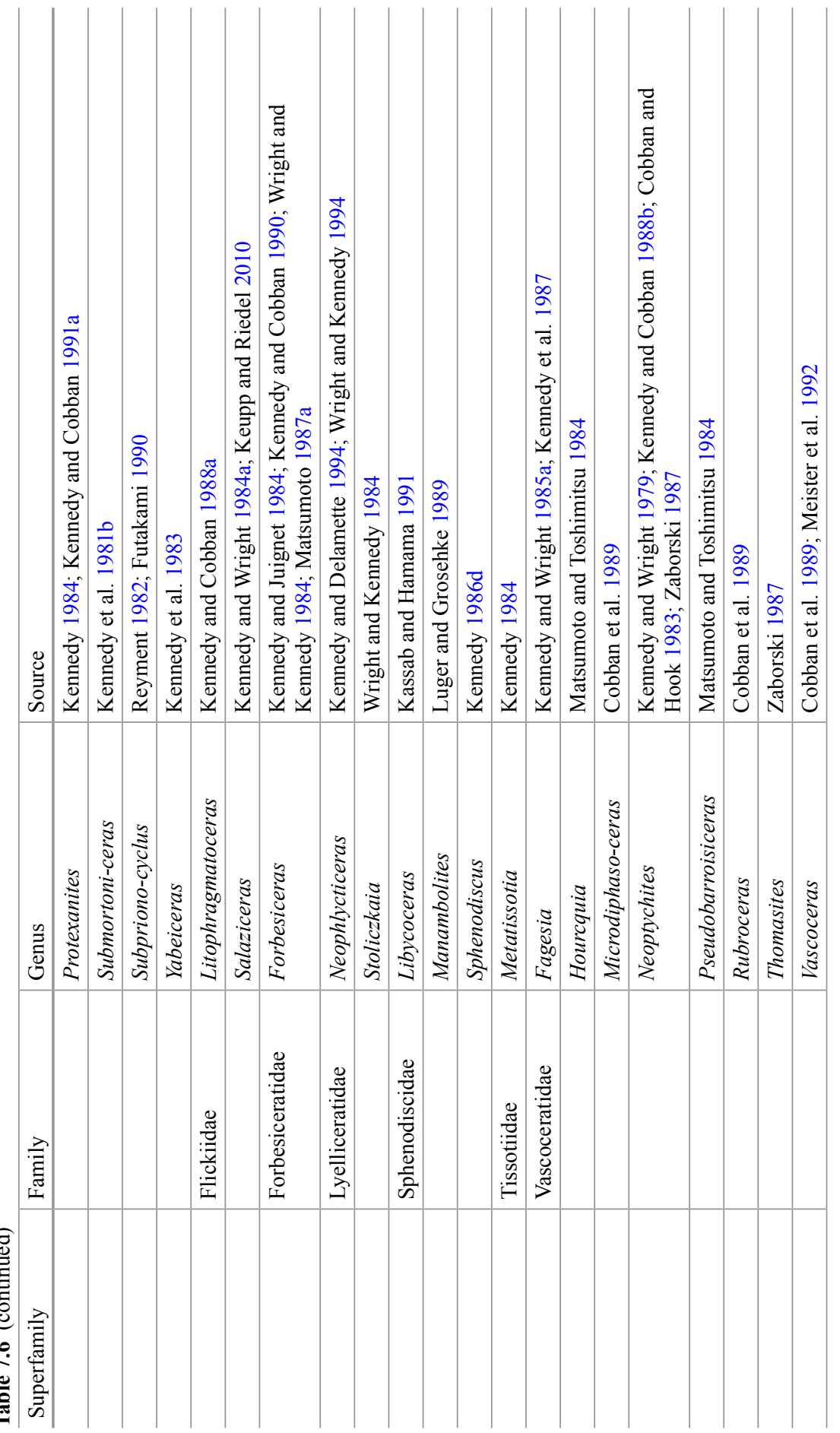




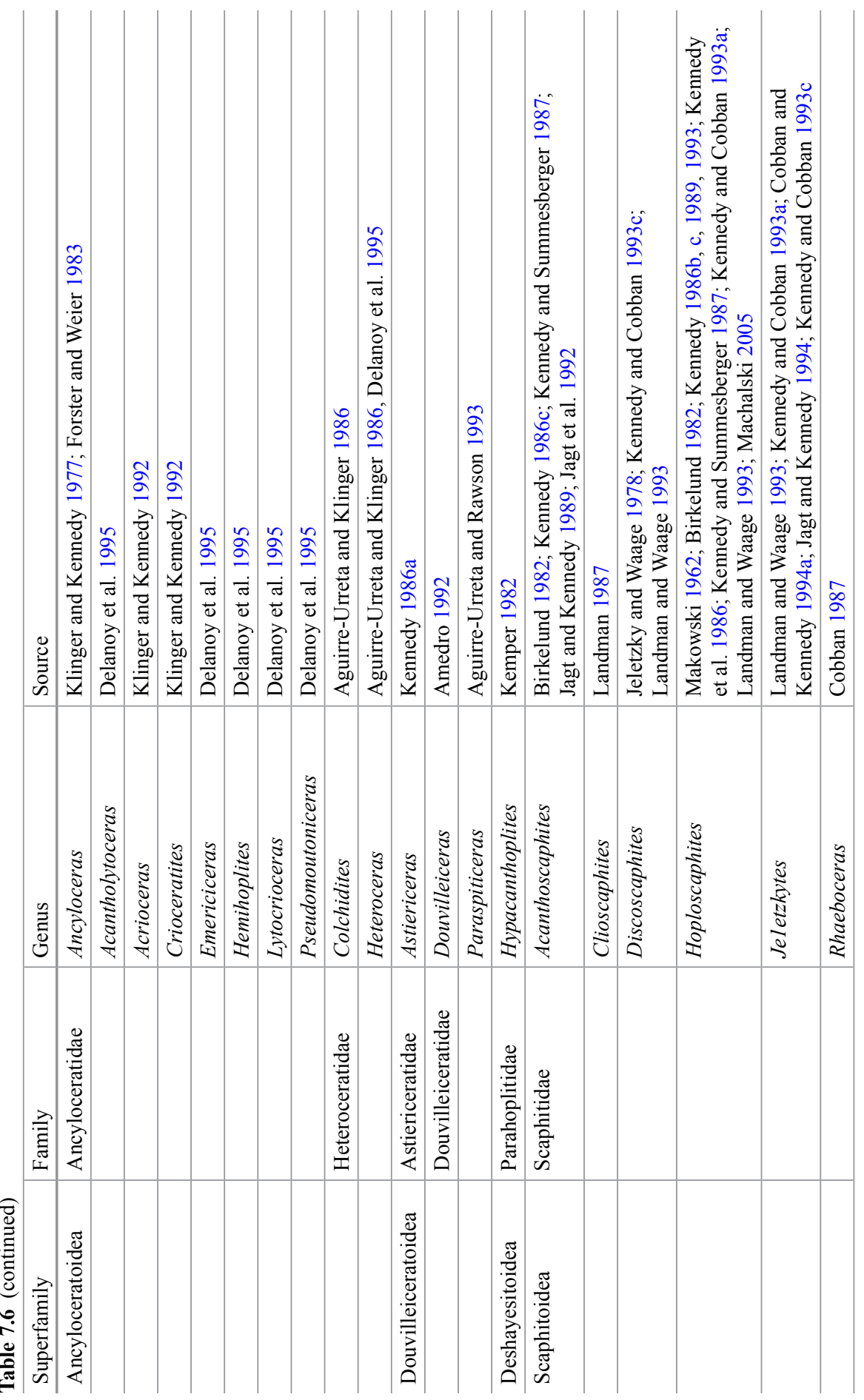




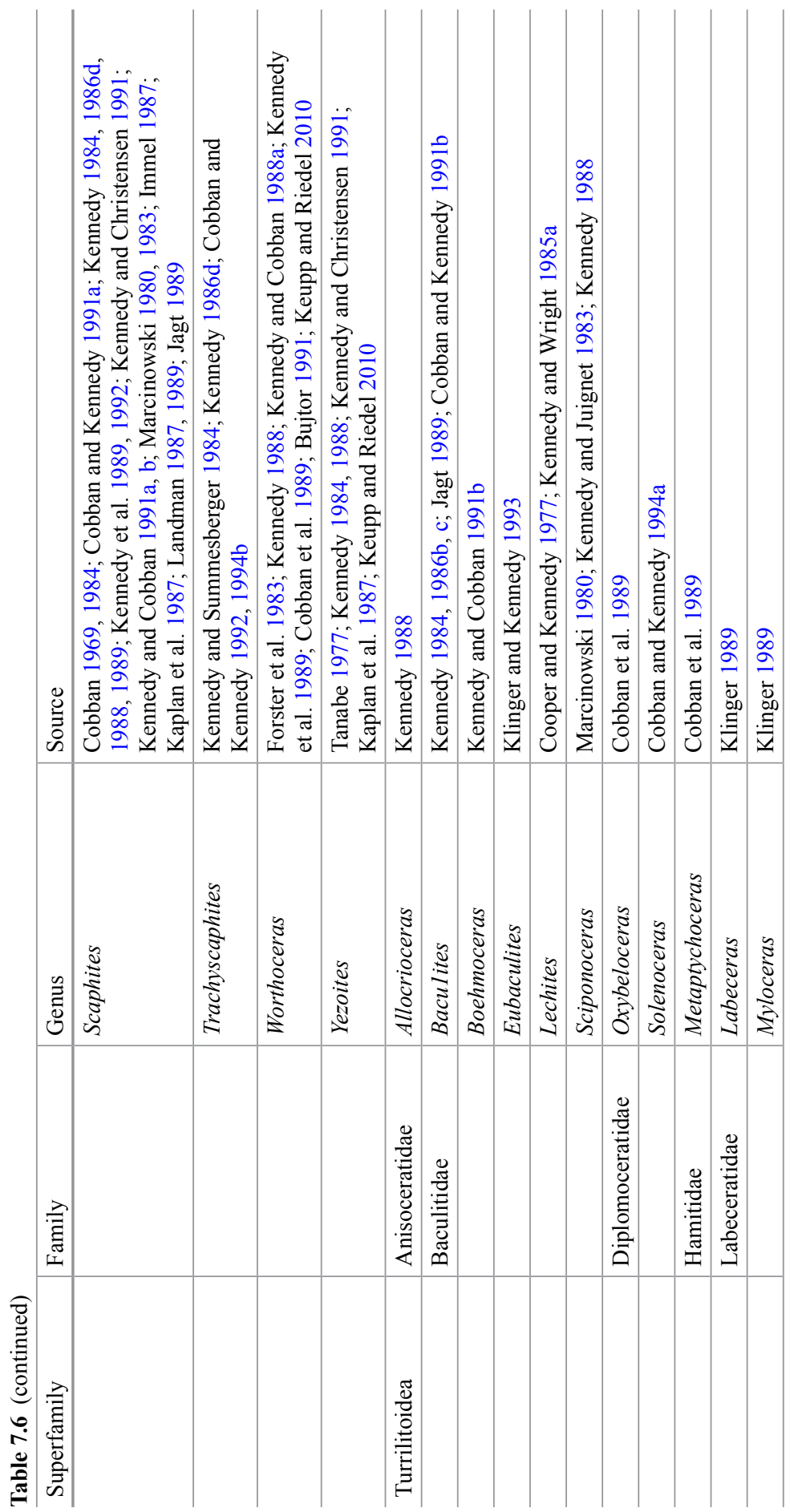




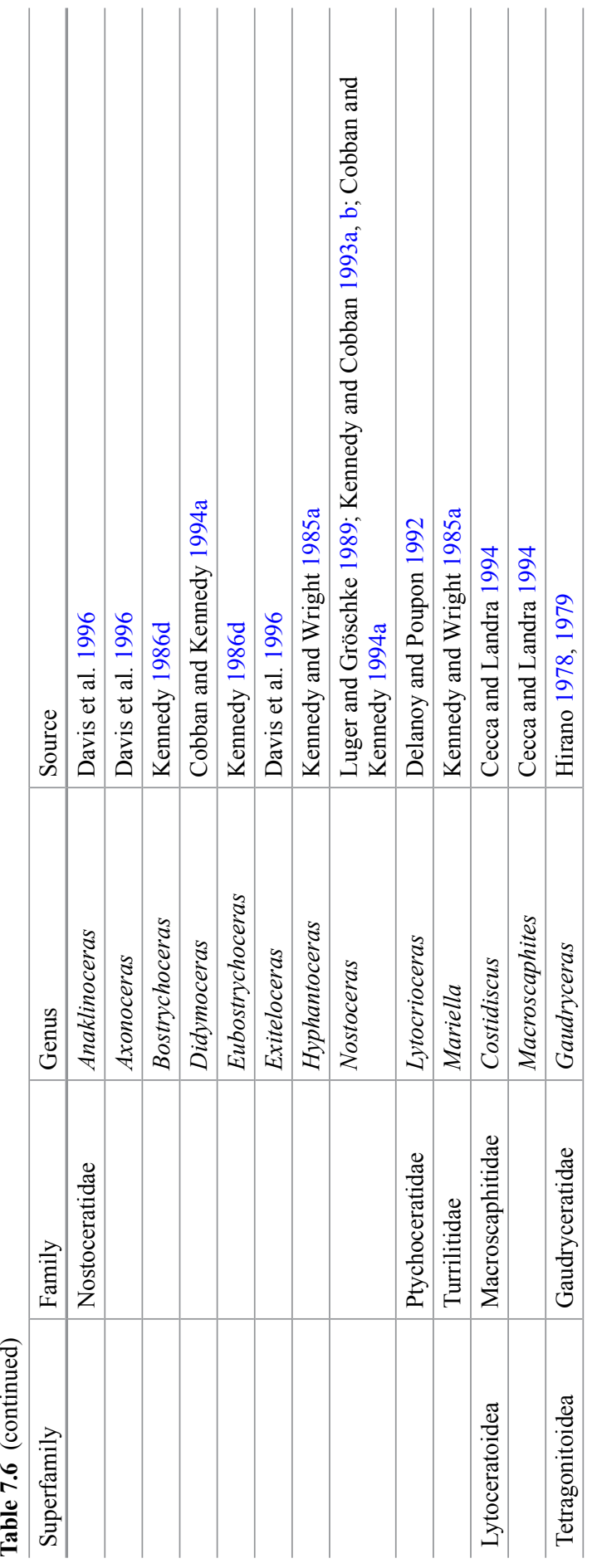


thick dorsal swelling, which gives it a pregnant appearance (e.g., Morton 1834; Kennedy and Cobban 1993a; Landman and Waage 1993; Machalski 2005). Speculatively, this bump provided extra space for the ovaries. In the corresponding microconch, the dorsal wall of the shaft is subparallel to the venter. There are also some differences in ornament (Davis et al. 1996). Landman and Waage (1993) examined the size-differences between the antidimorphs of the Maastrichtian species Hoploscaphites (Jeletzkytes) spedeni. Although the macroconchs are in average almost twice as large as their counterparts, the size distribution of both antidimorphs does overlap (Fig. 7.14). This size overlap varies between the species (Landman and Waage 1993), but it is not entirely clear whether the presence or absence of an overlap and its quality are predominantly controlled by (1) difference in adult diameter of the antidimorphs, (2) difference in intrasexual variability, (3) sample size or (4) ecology.

It is also remarkable that in the Maastrichtian Hoploscaphites comprimus, some morphological differences between the antidimorphs already occur in the normally coiled juvenile part (Landman and Waage 1993), making sexing of juvenile specimens possible.

Among the Turrilitoidea, there are also many cases of likely dimorphism, although often the main difference between the antidimorphs is size (e.g., Didymoceras, Bostrychoceras, Nipponites, Oxybeloceras, Sciponoceras; Kennedy 1988; Cobban and Kennedy 1994a). A nice example for dimorphism in the Lytoceratina is the genus Macroscaphites, in which the microconch develops a long straight shaft with a U-shaped hook at the end, while the macroconch consists only of a regularly coiled shell with a terminal constriction (Fig. 7.13). Most other lytoceratines display more normal kinds of dimorphism, i.e. mainly differences in size (Gaudryceras, Costidiscus, Tetragonites; Wiedmann 1973).

Davis et al. (1996) reported a couple of possible cases of Cretaceous trimorphism. One case was published by Hirano $(1978,1979)$ and concerns the lytoceratin Gaudryceras. A second case comprises scaphitids of the genera Scaphites, Clioscaphites, and Scaphites (Pteroscaphites). Wiedmann (1965) thought that the species of the latter genus were the microconchs of those of the former two genera, based on the same morphology of juvenile shells, same stratigraphic occurrences and the adult size and morphological differences. This interpretation appears to be incorrect because dimorphism was demonstrated for the macroconchs as proposed by Wiedmann (1965) by both Cobban (1951) and Landman (1987), and later also in Scaphites (Pteroscaphites) by Landman (1989). In many cases, the mix of intraspecific variability within both sexes, evolutionary changes, phenotypic plasticity (Wilmsen and Mosavinia 2011) and dimorphism blurs the patterns of disparity in ammonoid populations to such extent that the various phenomena can hardly be distinguished (Kennedy and Wright 1979; Reyment 1988; Kassab and Hamama 1991).

The ratios of numbers of macroconchs $(\mathrm{M})$ to microconchs $(\mathrm{m})$ have also been determined for various species (Davis et al. 1996):

Hoploscaphites constrictus, France: 1.9 M: 1 m (Kennedy 1986b),

H. constrictus, Poland: 2.2 M: $1 \mathrm{~m}$ (Makowski 1962),

H. nicolletii, South Dakota: 20 M: 1 m (Landman and Waage, 1993), 
H. comprimus, South Dakota: 1.5 M: 1 m (Landman and Waage 1993),

Menuites oralensis, Colorado: 2 M: 1 m (Cobban and Kennedy 1993),

M. portlocki complexus, Wyoming: 3.2 M: $1 \mathrm{~m}$ (Cobban and Kennedy 1993),

Scaphites hippocrepis, Wyoming: 0.5 M: $1 \mathrm{~m}$ (Cobban 1969),

S. hippocrepis III, Montana: 0.8 M: $1 \mathrm{~m}$ (Cobban 1969),

Scaphites 1eei III, New Mexico: 0.7 M: 1 m (Cobban 1969).

Another interesting aspect of dimorphism is the geographically varying ratio of the antidimorphs, for example in Metoicoceras (Kennedy 1988; Cobban et al. 1989) and Hoploscaphites (Landman and Waage 1993; Machalski 2005).

Some evolutionary trends in sexual dimorphism in Cretaceous ammonites have been described. Klinger and Kennedy (1989) examined Placenticeras from the Albian to the Maastrichtian and discovered that the early antidimorphs of this genus differed mainly in size, while younger, more derived forms differed also in ornament strength. Landman (1987) studied a population of Turonian Scaphites whitfieldi in which some of the specimens can be assigned to macroconchs or microconchs, while many forms display intermediate sizes and morphologies. In more derived scaphitids from the Maastrichtian, the assignment of antidimorphs can be done more easily because the dimorphism is more strongly expressed (Landman and Waage 1993).

\subsection{Open Questions}

\subsubsection{Intraspecific Variability of Antidimorphs}

Only a few studies are available dealing with the intraspecific variability of dimorphic species (compare De Baets et al. 2015a). This is understandable, because often it is difficult or impossible to get hold of a sufficiently large collection of mature specimens that are suitably preserved. Nevertheless, we are convinced that such populations of various ages are available in several museums worldwide, awaiting examination. Potential outcomes of such studies are a better understanding of the biological background of polymorphism, more confident separation of consecutive dimorphic species in evolutionary lineages, additional support for (or falsification of) dimorphism in cases of dubious dimorphism, an enhanced knowledge of the differences in variability between the antidimorphs, and raw data for further evolutionary studies.

\subsubsection{Macroevolution of Mature Modifications and Dimorphism}

Similar to the preceding topic, evolutionary aspects of dimorphism have only rarely or indirectly been addressed (one example is the work by Schweigert and Dietze 1998 on Oecoptychius and Phlycticeras; Fig. 7.9). It appears that the Haploceratoidea 


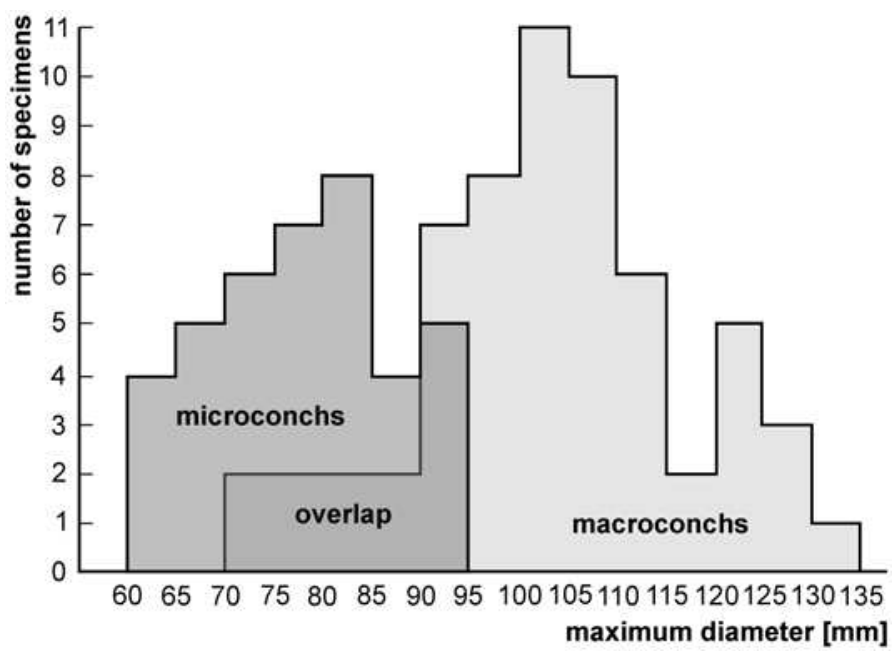

Fig. 7.14 Histogram of adult size in a collection of Maastrichtian Hoploscaphites spedeni from South Dakota. Macroconchs are usually larger than microconchs, but the size ranges overlap. (Redrawn from Davis et al. 1996 and Landman and Waage 1993)

could be an especially rewarding group in which to examine evolutionary changes in dimorphs (Fig. 7.11).

It has been suggested that evolutionary rates differed between antidimorphs; these rates may be difficult to quantify. By contrast, differences in variability of the antidimorphs through phylogeny could be studied in some small lineages (Fig. 7.14)

\subsubsection{Taxonomic Treatment of Antidimorphs}

Classically, partially because of the lack of knowledge, most antidimorphic pairs have been assigned to different taxa, occasionally reaching family level. Normally, members of one biological or morphological species should carry the same name according to the International Code of Zoological Nomenclature. As in trace fossils, the certainty of identity with respect to systematic nomenclature is often not given (for discussions see Callomon 1969; Lehmann 1981; Westermann 1969b). This is probably the reason why Demanet (1943) as well as Furnish and Knapp (1966) added various terms to the species name in order to state that they assume that two forms belong to the same species and at the same time, mark which form belongs to which sex. Although it appears reasonable to assign such antidimorphs, where it has been convincingly shown that they are conspecific, to the same species, this would imply applying different nomenclatorial rules depending on the state of knowledge (the problem could be solved by using partial names for cases that are not clear). An additional problem arises when diversity counts are carried out. If one species is knowingly subdivided into two, namely the antidimorphs, this would increase 
diversity artificially. Ammonoid researchers need to agree on a unified treatment that addresses this problem.

\subsubsection{Devonian to Triassic Dimorphism}

Compared to Paleozoic and Triassic dimorphism (if it existed at all), identification of Jurassic and Cretaceous antidimorphic pairs appears easy. Davis et al. (1996) have already found the seeming lack or scarcity of pre-Jurassic dimorphism intriguing. Taking the roots of Jurassic dimorphism into account, some researchers considered that dimorphism was absent before the Toarcian. By contrast, Guex (1981) stated that already in the Hettangian, dimorphism was not rare. This, in combination with the work of Urlichs (2009), points to the possibility of a reasonably common but not yet detected dimorphism prior to the Jurassic. Further support for this hypothesis comes from the repeated occurrences of morphologies that resemble Jurassic microconchs in various respects, such as e.g., Devonian Prolobites and Wocklumeria, Permian Elephantoceras and Adrianites, Triassic Coroceras and dwarf Arcestes or Lobites.

These are just some out of many open questions. Davis et al. (1996, p. 521) actually listed many more such questions at the end of their article. We do not repeat this here but recommend it to those further interested.

Acknowledgments Some of the insights in this chapter grew in the course of research projects with the numbers 200021-113956/1, 200020-25029, and 200020-132870 funded by the Swiss National Science Foundation SNF. Images were kindly provided by Neil Landman (New York, USA), Günter Schweigert and Gerd Dietl (both Stuttgart, Germany), Jean-Stéphane David (Saint Dolay, France), Victor Schlamp (Lappersdorf, Germany), Christian Obrist (Rickenbach, Switzerland), Didier Bert (La Mure-Argens, France), Patrick Branger (Poitiers cedex, France), Wolfgang Grulke (Oborne, UK), Andreas E. Richter (Augsburg, Germany), Pierre-Yves Boursicot (Hautsde-Seine, France). Margaret Yacobucci (Bowling Green), Izabela Ploch (Warsaw), and Kristin Polizzotto (Brooklyn) reviewed the manuscript and provided valuable constructive suggestions to improve it.

\section{References}

Aguirre-Urreta MB, Klinger HC (1986) Upper Barremian Heteroceratinae (Cephalopod, Ammonoidea) from Patagonia and Zululand, with comments on the systematics of the subfamily. Ann S Afr Mus 96(8):315-358

Aguirre-Urreta MB, Rawson PF (1993) The Lower Cretaceous ammonite Paraspiticeras from the Neuquen Basin, west-central Argentina. Neues Jahrb Geol Paläontol 188:187-233

Amedro F (1992) L'Albien du bassin anglo-Parisien: ammonites, zonation phylétique, séquences. Bull Cent Rech Explor Prod Elf-Aquitaine 16:187-233

Arkell WJ, Furnish WM, Kummel B, Miller AK, Moore RC, Schindewolf OH, Sylvester-Bradley PC, Wright CW (1957) Part L. Mollusca 4: Ammonoidea. In: Kaesler RL (ed) Treatise on invertebrate paleontology, Part L, Mollusca 4 (revised). GSA and University of Kansas Press, Lawrence 
Atrops F (1982) La sous-famille des Ataxioceratinae dans le Kimmeridgien inférieur du Sud-Est de la France. Doc Lab Géol Lyon 83:1-371

Atrops F, Reboulet S (1995) Neolissoceras (Carinites), nouveau sous-genre d'ammonites du Valanginien du bassin vocontien (SE de la France). CR Acad Sci Paris 321(IIa):1203-1210

Baloge P-A, Cariou E (2001) Les Distichoceratinae (Ammonitina) du Centre-Ouest de la France. Palaeontogr A 261:125-159

Bardhan S, Dutta R, Chanda P, Mallick S (2012) Systematic revision and sexual dimorphism in Choffatia (Ammonoidea: Perisphinctoidea) from the Callovian of Kutch, India. Palaeoworld 21:29-49

Barrande J (1877) Systême Silurien du centre de la Bohème, Première Partie: Récherches paléontologiques. 2, Classes des Mollusques, Ordre des Céphalopodes. By the author, Paris

Basse, E (1952) Céphalopodes, Nautiloidea, Ammonoidea. In: Pivéteau J (ed) Traité de Paléontologie, vol 2. J. B. Baillière, Paris, pp 522-688

Bert D (2003) Etude de Protophites vannii sp. nov. (Ammonoidea), sous-zone a Cardioceras vertebrale, Oxfordien moyen, et evolution du genre Protophites Ebray, 1860. Riviéra Sci 87:69-84

Birkelund T (1982) Maastrichtian ammonites from Hemmoor, Niederelbe (NW-Germany). Geol J A 61:13-33

de Blainville MHD (1840) Prodrome d'une monographie des ammonites. In: Supplément du Dictionnaire des Sciences Naturelles, Bertrand. Paris, pp 1-31

Blind W, Jordan R (1979) “Septen-Gabelung” an einer Dorsetensia romani (Oppel) aus dem nordwestdeutschen Dogger. Paläontol Z 53(3/4):137-141

Bogoslovsky BI (1969) Devonskie ammonoidei. I. Agoniatity, vol 124 (Trudy Paleontologicheskogo Instituta Akademiya Nauk SSSR) Nauka, Moskva, pp 1-341

Bonnot A, Neige P, Tarkowski R, Marchand D (1994) Mirosphinctes Schindewolf et Euaspidoceras Spath du Niveau Vert de Zalas [Pologne] (Oxfordien Inférieur, Zone a Cordatum): Dimorphes sexuels? Bull Pol Acad Sci (Earth Sciences) 42:181-205

Bonnot A, Boursicot P-Y, Ferchaud P, Marchand D (2008) Les Pseudoperisphinctinae (Ammonitina, Perisphinctidae) de l'horizon à Leckenbyi (Callovien supérieur, zone à Athleta) de Montreuil-Bellay (Maine-et-Loire, France) et description d'une nouvelle espèce, Choffatia isabellae. Carnets Géol 5:1-27

Brinkmann R (1929) Monographie der Gattung Kosmoceras. Abh Ges Wiss Göttingen, Math-Phys KI, NF 13(4):1-123

Brochwicz-Lewiński W, Różak Z (1976) Some difficulties in recognition of sexual dimorphism in Jurassic perisphinctids (Ammonoidea). Acta Palaeontol Pol 21:115-124

Brooks MJ (1991) The ontogeny of sexual dimorphism: Quantitative models and a case study in labrisomid blennies (Teleostei: Paraclinus). Syst Zool 40(3):71-283

Bucher H (1992) Ammonoids of the Shoshonensis Zone (Middle Anisian, Middle Triassic) from NW Nevada. Jahrb Geol Bundesanst 135(2):423-466

Bucher H, Guex J (1990) Rythmes de croissance chez les ammonites triasiques. Bull Geol Lausanne 308:191-209

Bucher H, Landman NH, Klofak, SM, Guex J (1996) Mode and rate of shell growth. In: Landman NH, Tanabe K, Davis RA (eds) Ammonoid paleobiology. Plenum, New York

Bujtor I (1991) A new Worthoceras (Ammonoidea, Cretaceous) from Hungary, and remarks on the distribution of Worthoceras species. Geol Mag 128:537-542

Bujtor L (1993) Valanginian ammonite fauna from the Kisújbánya Basin (Mecsek Mts., South Hungary) and its palaeobiogeographical significance. Neues Jahrb Geol Paläontol Abh 188:103-131

Bulot L, Company M, Thieuloy J-P (1990) Origine, évolution et systematique du genre Valanginien Saynoceras (Ammonitina, Olcostephaninae). Geobios 23:399-413

Callomon JH (1955) The ammonite succession in the Lower Oxford Clay and Kellaway beds at Kidlington, Oxfordshire, and the zones of the Callovian Stage. Phil Trans R Soc Lond (Biol) 239:215-264

Callomon JH (1963) Sexual dimorphism in Jurassic ammonites. Trans Leic Lit Philos Soc 57:2156 
Callomon JH (1969) Dimorphism in Jurassic Ammonoidea. Some reflections. In: Westermann GEG (ed) Sexual dimorphism in fossil Metazoa and taxonomic implications. International union of geological sciences. A 1 Schweizerbart, Stuttgart, pp 111-125

Callomon JH (1981) Dimorphism in ammonoids. In: House MR, Senior JR (eds) The Ammonoidea, vol 18. Systematics Association by Academic Press, London pp 257-273

Callomon JH (1985) The evolution of the Jurassic ammonite family Cardioceratidae. Spec Pap Palaeontol 3349-90

Callomon JH (1988) [Review of] Matyja BA (1986) Developmental polymorphism in Oxfordian ammonites. Acta Geol Pol 36:37-68 (Cephalopod Newsl 9:14-16)

Callomon JH, Gradinaru E (2005) From the thesaurus of the museum collections. I. Liassic ammonites from Munteana (Svinita Zone, Southern Carpathians, Romania). Acta Palaeontol Rom 5:49-65

Cariou E (1984). Les Reineckeiidae (Ammonitina, Callovien) de la Tethys occidentales. Dimorphisme et evolution. Etude a partir des gisements du centre-ouest de la France. Doc Lab Géol Lyon HS 8:1-599

Cecca E, Landra G (1994) Late Barremian-early Aptian ammonites from the Maiolica formation near Cesana Brianza (Lombardy Basin, northern Italy). Riv It Paleont Strat 100(3):395-422

Cecca F, Rouget I (2006) Anagenetic evolution of the Early Tithonian ammonite genus Semiformiceras tested with cladistic analysis. Palaeontology 49:1069-1080

Charpy N, Thierry (1976) Dimorphisme et polymorphisme chez Pachyceras Bayle (Ammonitina, Stephanocerataceae) du Callovien supérieur (Jurassique moyen). Haliotis 6:185-218

Chimšiašvili NG, Kamsyeva-Elpatevskaja VG, Bodylevskij VI et al. (1958) Nadsemejstvo Perisphinctaceae. In: Orlov JA (ed) Osnovy paleontologii, molluski-golovonogie, II. Moskva, pp 85-96

Cobban WA (1951) Scaphitoid cephalopods of the Colorado Group. US Geol Surv Prof Pap 239:1-42

Cobban WA (1953) Cenomanian ammonite fauna from the Mosby Sandstone of central Montana, US Geol Surv Prof Pap 243D:45-55

Cobban WA (1969) The Late Cretaceous ammonites Scaphites leei Reeside and Scaphites hippocrepis (DeKay) in the Western Interior of the United States. US Geol Surv Prof Pap 619:1-29

Cobban WA (1984) Molluscan record from a mid-Cretaceous borehole in Weston County, Wyoming. US Geol Surv Prof Pap 1271:1-24

Cobban WA (1987) The Upper Cretaceous ammonite Rhaeboceras Meek in the Western Interior of the United States. US Geol Surv Prof Pap 1477:1-15

Cobban WA (1988a) Tarrantoceras Stephenson and related ammonoid genera from Cenomanian (Upper Cretaceous) rocks in Texas and the Western Interior of the United States. US Geol Surv Prof Pap 1473:1-30

Cobban WA (1988b) The Upper Cretaceous ammonite Watinoceras Warren in the Western Interior of the United States. US Geol Surv Bull 1788:1-15

Cobban WA, Hook SC (1983) Mid-Cretaceous (Turonian) ammonite fauna from Fence Lake area of west-central New Mexico, NM. Bur Mines Miner Resour Mem 41:1-50

Cobban WA, Kennedy WJ (1990) Variation and ontogeny of Calycoceras (Proeucalycoceras) canitaurinum (Haas, 1949) from the Upper Cretaceous (Cenomanian) of the Western Interior of the United States. US Geol Surv Bull 1881:BI-B7

Cobban WA, Kennedy WJ (1991a) A giant scaphite from the Turonian (Upper Cretaceous) of the Western Interior of the United States. US Geol Surv Bull 1934:A1-A2

Cobban WA, Kennedy WJ (1991b) Evolution and biogeography of the Cenomanian (Upper Cretaceous) ammonite Metoicoceras Hyatt. 1903, with a revision of Metoicoceras praecox Haas, 1949. US Geol Surv Bull 1934:BI-B11

Cobban WA, Kennedy WJ (1991c) Baculites thomi Reeside 1927, an Upper Cretaceous ammonite in the Western Interior of the United States. US Geol Surv Bull 1934:C

Cobban WA, Kennedy WJ (1992) Campanian Trachyscaphites spiniger ammonite fauna in northeast Texas. Palaeontology 35(1):63-93

Cobban WA, Kennedy WJ (1993) The Upper Cretaceous dimorphic pachydiscid ammonite Menuites in the Western Interior of the United States. US Geol Surv Prof Pap 1533:1-14 
Cobban WA, Kennedy WJ (1994a) Upper Cretaceous ammonites from the Coon Creek Tongue of the Ripley Formation at its type locality in McNairy County, Tennessee. US Geol Surv Bull 2073:BI-B12

Cobban WA, Kennedy WJ (1994b) Middle Campanian (Upper Cretaceous) ammonites from the Pecan Gap Chalk of central and northeastern Texas. US Geol Surv Bull 2073:D1-D9

Cobban WA, Hook SC, Kennedy WJ (1989) Upper Cretaceous rocks and ammonite faunas of southwestern New Mexico. NM Bur Mines Miner Resour Mem 45:1-137

Coemme S (1917) Note critique sur le genre Cadomoceras. Bull Soc Géol Fr 417:44-54

Collins D, Ward PD (1987) Adolescent growth and maturity in Nautilus. In: Saunders WB, Landman NH (eds) Nautilus. The biology and paleobiology of a living fossil, vol 6. Plenum Press, New York 421-432 (Topics in Geobiology)

Contini D, Marchand D, Thierry J (1984) Réflexion sur la notion de genre et de sous-genre chez les ammonites: Exemples pris essentiellement dans le Jurassique moyen. Bull Soc Géol Fr 26(4):653-661

Cooper MR, Kennedy WJ (1977) A revision of the Baculitidae of the Cambridge Greensand. Neues Jahrb Geol Paläontol Mh 11:641-658

Cooper MR, Kennedy WJ (1979) Uppermost Albian (Stoliczkaia dispar zone) ammonites from the Angolan littoral. Ann S Afr Mus 77(10):175-308

Cooper MR, Kennedy WJ (1987) A revision of the Puzosiinae (Cretaceous ammonites) of the Cambridge Greensand. Neues Jahrb Geol Paläontol Abh 174(1):105-121

Cope JCW (1992) Dimorphism in a Tethyan Early Jurassic Juraphyllites. Lethaia 25:439-441

Cox B.M. (1988) English Callovian (Middle Jurassic) perisphinctid ammonites. Part 1. Monogr Palaeontogr Soc Lond 140:1-54

Czarnocki J (1989) Klimenie Gór Świętokrzyskich (Prace Państwowego Instytutu Geologicznego), vol 127 Wydawnictwa Geologiczne, Warszawa, pp 1-91

Davis RA (1972) Mature modification and dimorphism in selected late Paleozoic ammonoids. Bull Am Paleontol 62(272):23-130

Davis RA, Furnish WM, Glenister BF (1969) Mature modification and dimorphism in late Paleozoic ammonoids. In: Westermann GEG (ed) Sexual dimorphism in fossil Metazoa and taxonomic implications (IUGS, Series A1). Schweizerbart, Stuttgart, pp 101-110

Davis RA, Landman NH, Dommergues J-L, Marchand D, Bucher H (1996) Mature modifications and dimorphism in ammonoid cephalopods. In: Landman NH, Tanabe K, Davis RA (eds) Ammonoid paleobiology. Plenum, New York

Davitashvili LSh, Khimshiashvili NG (1954) On the question of the biological significance of the apertural formation of ammonites. Works Paleobio Sect Acad Sci Georgian Soviet Soc Re 2:44-76 [in Russian]

De Baets K Klug C Korn D Landman NH (2012) Evolutionary trends in ammonoid embryonal development. Evolution 66:1788-1806

De Baets K Klug C Monnet C (2013a) Intraspecific variability through ontogeny in early ammonoids. Paleobiology 39:75-94

De Baets K Klug C Korn D Bartels C Poschmann M (2013b) Emsian Ammonoidea and the age of the Hunsrück Slate (Rhenish Mountains, Western Germany). Palaeontogr A 299(1-6):1-113

De Baets K, Bert D, Hoffmann R, Monnet C, Monnet C, Yacobucci MM, Klug C (2015a) Ammonoid Intraspecific Variability. This volume

De Baets K, Landman NH, Tanabe K (2015) Ammonoid embryonic development. This volume

Delanoy G, Poupon A (1992) Sur le genre Lytocrioceras Spath, 1924 (Ammonoidea, Ancyloceratina). Geobios 25(3):367-382

Delanoy G, Ropolo P, Magnin A, Autran G, Poupon A, Gonnet R (1995) Sur le dimorphisme chez les Ancyloceratina (Ammonoidea) du Crétacé inférieur. Comptes Rendus Acad Sci Sér IIa 321:537-543

Demanet F (1943) Les horizons marins du Westphalien de la Belgique et leurs faunes. Mém Mus R Hist Nat Belg 101:1-166

Dietl G (2013) Der Braune Jura ober- $\varepsilon$ und $\zeta$. Fossilien. Sonderheft "Der Braunjura am Fuß der Schwäbischen Alb", pp 30-46 
Dietze V, Callomon JH, Schweigert G, Chandler RB (2005) The ammonite fauna and biostratigraphy of the Lower Bajocian (Ovale and Laeviscula zones) of E Swabia (S Germany). Suttg Beitr Naturk B 353:1-82

Dietze V, Chandler RB, Callomon JH (2007) The ovale zone (Lower Bajocian, Middle Jurassic) at Little Down Wood (Dundry Hill, Somerset, SW England). Stuttg Beitr Naturk B 368:1-45

Dietze V, Bosch K, Franz M, Kutz M, Schweigert G, Wannenmacher N, Studer S (2013) Die Humphriesianum-Zone (Unter-Bajocium, Mitteljura) am Kahlenberg bei Ringsheim (Oberrheingraben, SW Deutschland). Palaeodiversity 6:29-61

Djanélidzé A (1922) Les Spiticeras du sud-est de la France. Mém Explic Carte Géol détaill Fr VI: $1-255$

Doguzhaeva L (1982) Rhythms of ammonoid shell secretion. Lethaia 15:385-394

Doguzhaeva LA (1981) The wrinkle layer in the shell of ammonoids. Paleontol Z 1:38-48 [In Russian]

Doguzhaeva LA, Kabanov GK (1988) Muscle scars in ammonoids. Dokl Akad Nauk USSR 301:210-212

Doguzhaeva LA, Mikhailova IA (1991) New data on muscle system of heteromorphic ammonites. Dokl Akad Nauk USSR 318(4):981-984

Doguzhaeva LA, Mikhailova IA (2002) The jaw apparatus of the heteromorphic ammonite Australiceras whitehouse, 1926 (Mollusca: Cephalopoda) from the Aptian of the Volga Region. Dokl Akad Nauk USSR 382:38-40

Doguzhaeva LA, Mutvei H (1991) Organization of the soft body in Aconeceras (Ammonitina), interpreted on the basis of shell morphology and muscle scars. Palaeontogr A 218:17-33

Doguzhaeva LA, Mutvei H (1993) Shell ultrastructure, muscle scars, and buccal apparatus in ammonoids. Geobios 15:111-119

Doguzhaeva LA, Mutvei H (1996) Attachment of the body to the shell in ammonoids. In: Landman NH, Tanabe K, Davis RA (eds) Ammonoid paleobiology. Plenum, New York

Dommergues J-L (1993) The Jurassic ammonite Coeloceras: An atypical example of dimorphic progenesis elucidated by cladistics. Lethaia 27(2):143-152

Donovan DT, Callomon JH, Howarth MK (1981). Classification of the Jurassic Ammonitina. In: House MR, Senior JR (eds) The Ammonoidea, vol 18. Systematics Association by Academic Press, pp 101-155

Dzik J (1984) Phylogeny of the Nautiloidea. Palaeont Pol 45:1-220

Dzik J (1990a) The concept of chronospecies in ammonites. In: Pallini G, Cecca F, Cresta S, Santantonio M (eds) Atti del secondo convegno internazionale Fossili Evoluzione Ambiente. Pergola

Dzik J (1990b) The ammonite Acrochordiceras in the Triassic of Silesia. Acta Palaeontol Pol 35(1-2):49-65

Ebbighausen V, Korn D (2007) Conch geometry and ontogenetic trajectories in the triangularly coiled Late Devonian ammonoid Wocklumeria and related genera. Neues Jahrb Geol Paläontol Abh 244:9-41

Elmi S (1967) Le Lias supérieur et le Jurassique moyen de l'Ardeche. Docum Lab. Géol Lyon 19(1-3): $1-845$

Elmi S, Mangold C (1966) Eude de quelques Oxycerites du Bathonien Inférieur. Trab Lab Géol Fac Sc Lyon, NS 13:143-181

Enay R (1966) L'Oxfordien dans la moitié sud du Jura français. Nouv Arch Mus Hist Nat Lyon $8: 1-624$

Ernst HU, Klug C (2011) Perlboote und Ammonshörner weltweit. Nautilids and Ammonites worldwide. Pfeil Verlag, München

Etches S, Clarke J, Callomon J (2009) Ammonite eggs and ammonitellae from the Kimmeridge clay formation (Upper Jurassic) of Dorset, England. Lethaia 42:204-217

Fatmi AN (1969) Dimorphism in some Jurassic and Lower Cretaceous ammonites from West Pakistan. Geonews (Geol. Surv. Pakistan) 1(2):6-13

Foord AH, Crick GC (1897) Catalogue of the fossil Cephalopoda in the British Museum (Natural History). Part III. Containing the Bactritidae and Part of the suborder Ammonoidea. British Museum (Natural History), London 
Förster R, Weier H (1983) Ammoniten und Alter der Niongala-Schichten (Unterapt, Slid-Tanzania). Mitt Bayer Staatsslg Paläontol Hist Geol 23:51-76

Förster R, Meyer R, Risch H (1983) Ammoniten und planktonische Foraminiferen aus den Eibrunner Mergeln (Regensburger Kreide, Nordostbayern). Zitteliana 10:123-141

Frest TJ, Glenister BF, Furnish WM (1981) Pennsylvanian-Permian Cheiloceratacean ammonoid families Maximitidae and Pseudohaloritidae. Paleontol Soc Mem 11 (Paleontol suppl to) 55(3): $1-46$

Furnish WM, Knapp WD (1966) Lower Pennsylvanian fauna from eastern Kentucky; Part 1, Ammonoids. J Paleontol 40(2):296-308

Futakami M 1990. Turonian collignoniceratid ammonites from Hokkaido, Japan. Stratigraphy and paleontology of the Cretaceous in the Ishikari province, central Hokkaido. (Part 3, 1, vol 1). Kawamura Gakuen Women's University, Japan, pp 235-260

Gabr HR, Hanlon RT, Hanafy MH, El-Etreby SG (1998) Maturation, fecundity and seasonality of reproduction of two commercially valuable cuttlefish, Sepia pharaonis and S. dollfusi, in the Suez Canal. Fisch Res 36:99-115

Ganguly T, Bardhan S (1993) Dimorphism in Placenticeras mintoi from the Upper Cretaceous Bagh Beds, central India. Cretac Res 14:747-756

Gauthier H, Branger P, Boursicot P-Y, Trévisan M, Marchand D (2002) La faune d'Orthogarantiana Bentz (Garantianinae, Stephanoceratidae) de la sous-zone à Polygyralis (z. à Niortense, Bajocien sup.) nouvellement découverte au nord de Niort (Deux-Sèvres, France). Une preuve du dimorphisme Orthogarantiana/Strenoceras. Géol Fr 1:81-86

Gemmellaro GG (1887) La fauna dei calcari con Fusulina della valle del Fiume Sosio nella Provincia di Palermo. Fascio I-Cephalopoda, Ammonoidea. G Sci Nat Econ 19:1-106

Geyer OF (1969) The ammonite genus Sutneria in the Upper Jurassic of Europe. Lethaia 2:63-72

Gould SJ (1977) Ontogeny and phylogeny. Harvard University Press, Cambridge

Griffin LE (1900) The anatomy of Nautilus pompilius. Mem Natl Acad Sci 8:101-203

Guex J (1967) Dimorphisme sexuel d'un groupe d'Hammatoceras et position systématique du genre Onychoceras. Bull Soc Vaud Sci Nat 69:423-434

Guex J (1968) Note préliminaire sur le dimorphisme sexuel des Hildocerataceae du Toarcien moyen et supérieur de l'Aveyron (France). Soc Vaud Sci Nat Lausanne Bull 70(327):57-84

Guex J (1973) Dimorphisme des Dactylioceratidae du Toarcien. Eclogae Geol Helv 66:545-583

Guex J (1981) Quelques cas de dimorphisme chez les ammonïodés du Lias inférieur. Bull Soc Vaud Sci Nat 75:239-248

Hahn W (1971) Die Tulitidae S. Buckman, Sphaeroceratidae S. Buckman und Clydoniceratidae S. Buckman (Ammonoidea) des Bathoniums (Brauner Jura $\varepsilon$ ) im südwestdeutschen Jura. Jahresh Geol Landesamtes Baden-Württ 13:55-122

Hammer Ø, Bucher H (2006) Generalized ammonoid hydrostatics modelling, with application to Intornites and intraspecific variation in Amaltheus. Paleontol Res 10:91-96

Hanlon RT, Forsythe JW (2008) Sexual cannibalism by Octopus cyanea on a Pacific coral reef. Mar Freshw Behav Physiol 41:19-28

Haug E (1897) Observations a la suite d'une note de Ph. Glangeaud sur las forme de l'ouverture de quelques ammonites. Bull Soc Géol Fr Ser 325:107

Hayasaka S, Oki K, Tanabe K, Saisho T, Shinomiya A (1987) On the habitat of Nautilus pompilius in Tafton Strait (Philippines) and the Fiji Islands. In: Saunders WB, Landman NH (eds) Nautilus. The biology and paleobiology of a living fossil. Plenum, New York

Hillebrandt A, Krystyn L (2009) On the oldest Jurassic ammonites of Europe (Northern Calcareous Alps, Austria) and their global significance. Neues Jahrb Geol Paläontol Abh 253:163-195

Hirano H (1978) Phenotypic substitution of Gaudryceras (a Cretaceous ammonite). Trans Proc Palaeontol Soc Jpn NS 109:235-258

Hirano H (1979) Importance of transient polymorphism in systematics of Ammonoidea. The Gakujutsu Kenkyu Sch Educ Waseda Univ Ser Biol Geol 28:35-43

Hoffmann R (2010) New insights on the phylogeny of the Lytoceratoidea (Ammonitina) from the septal lobe and its functional interpretation, vol 29. Revue de Paléobiologie, Genève, pp 1-156 
Hoffmann R, Schultz JA, Schellhorn R, Rybacki E, Keupp H, Gerden SR, Lemanis R, Zachow S (2013) Non-invasive imaging methods applied to neo- and paleontological research. Biogeosci Discuss 10:18803-18851. doi:10.5194/bgd-10-18803-2013

Housa V (1965) Sexual dimorphism and the system of Jurassic and Cretaceous Ammonoidea (Preliminary note). Casas Nar Muz 134:33-35

House MR (1970) The goniatite wrinkle layer. Smithson Contrib Paleontol 3:23-32

Howarth MK (1992) Tithonian and Berriasian ammonites from the Chia Gara Formation innorthern Iraq. Palaeontology 35(3):597-655

Howarth MK (2013) Part L, Revised, Volume 3B, Chapter 4: Psiloceratoidea, Eoderoceratoidea, Hildoceratoidea. Treatise 57:1-139

Immel H (1987) Die Kreideammoniten der nordlichen Kalkalpen. Zitteliana 15:3-163

Ivanov AN (1971) About some growth alterations in ammonite shells. Bull Mosc Soc Nat Hist Geol Sect 46:155 [in Russian]

Ivanov AN (1975) Late ontogeny of ammonites and, in particular, of the micro-, macro-, and megaconchs. Coll Stud Notes Sci W Yarosl St Ped Inst 142:5-57 [in Russian]

Ivanov AN (1985) Were micro- and macroconchs of ammonites sexual dimorphs? In: Taxonomy and ecology of Cephalopoda. Scientific papers. Academy of Sciences of the USSR, Zoological Institute, Scientific Council on the Problem of "Biological Bases of Utilization, Remaking, and Protection of the Animal World", Malacological Committee, Leningrad, 32-34 [in Russian]

Jackson GD, Moltschaniwskyj NA (2002) Spatial and temporal variation in growth rates and maturity in the Indo-Pacific squid Sepioteuthis lessoniana (Cephalopoda: Loliginidae). Mar Biol 140:747-754

Jagt JWM (1989) Ammonites from the early Campanian Vaals Formation at the CPL Quarry (Haccourt, Liege, Belgium) and their stratigraphic implications. Meded. Rijks Geol Dienst 43(1): $1-18$

Jagt JWM, Kennedy WJ (1989) Acanthoscaphites varians (Lopuski, 1911) (Ammonoidea) from the Upper Maastrichtian of Haccourt, NE Belgium. Geol Mijnb 68:237-240

Jagt JWM, Kennedy WJ (1994) Jeletzkytes dorfi Landman and Waage 1993, a North American ammonoid marker from the lower Upper Maastrichtian of Belgium, and the numerical age of the Lower/Upper Maastrichtian boundary. Neues Jahrb Geol Paläontol Mh 4:239-245

Jagt JWM, Kennedy WJ, Burnett J (1992) Acanthoscaphites tridens (Kner, 1848) (Ammonoidea) from the Vijlen Member (Lower Maastrichtian) of Gulpen, Limburg, The Netherlands. Geol Mijnb 71:15-21

Jeletzky JA, Waage KM (1978) Revision of Ammonites conradi Morton 1834, and the concept of Discoscaphites Meek 1870. J Paleontol 52:1119-1132

Kakabadze MV (2004) Intraspecific and intrageneric variabilities and their implication for the systematics of Cretaceous heteromorph ammonites; a review. Scr Geol 128:17-37

Kant R (1973) Allometrisches Wachstum paläozoischer Ammonoideen: Variabilität und Korrelation einiger Merkmale. Neues Jahrb Geol Paläontol Abh 143:153-192

Kaplan U, Kennedy WJ, Wright CW (1987) Turonian and Coniacian Scaphitidae from England and North-Western Germany. Geol J 103:5-39

Kassab AS, Hamama HH (1991) Polymorphism in the Upper Cretaceous ammonite Libycoceras ismaeli (Zittel). J Afr Earth Sci 12(3):437-448

Keferstein W (1866) Cephalopoden. In: Die Klassen und Ordnungen des Thierreichs wissenschaftlich dargestellt in Wort und Bild von Hans Georg Bronn. Fortgesetzt von Wilhelm Keferstein, (vol 3, part 2). Verlag Winter, Leipzig, pp 1337-1406

Kemper E (1982) Die Ammoniten des späten Apt und frühen Alb Nordwestdeutschlands. Geol Jahrb A 65:553-557

Kennedy WJ (1984) Systematic paleontology and stratigraphic distribution of the ammonite faunas of the French Coniacian. Spec Pap Palaeontol 31:1-160

Kennedy WJ (1986a) Observations on Astiericeras astierianum (d'Orbigny, 1842) (Cretaceous Ammonoidea). Geol Mag 123(5):507-513

Kennedy WJ (1986b) The ammonite fauna of the Calcaire a Baculites (Upper Maastrichtian) of the Cotentin Peninsula (Manche, France). Palaeontology 29:25-83 
Kennedy WJ (1986c) The ammonite fauna of the type Maastrichtian with a revision of Ammonites colligatus Binkhorst 1861. Bull Inst R Sci Nat Belg (Sciences de la Terre) 56:151-267

Kennedy WJ (1986d) Campanian and Maastrichtian ammonites from northern Aquitaine, France. Spec Pap Palaeontol 36:1-145

Kennedy WJ (1988) Late Cenomanian and Turonian ammonite faunas from north-east and central Texas. Spec Pap Palaeontol 39:1-131

Kennedy WJ (1989) Thoughts on the evolution and extinction of Cretaceous ammonites. Proc Geol Assoc 100(3):251-279

Kennedy WJ (1993) Campanian and Maastrichtian ammonites from the Mons Basin and adjacent areas. vol 63. Bull lnst R Sci Nat Belg (Sciences de la Terre) 63:99-131 (Belgium)

Kennedy WJ, Christensen WK (1991) Coniacian and Santonian ammonites from Bornholm, Denmark. Bull Geol Soc Den 38:203-226

Kennedy WJ, Cobban WA (1976) Aspects of ammonite biology, biogeography, and biostratigraphy. Spec Pap Palaeontol 17:1-93

Kennedy WJ, Cobban WA (1988a) Litophragmatoceras incomptum gen. et sp. nov. (Cretaceous Ammonoidea), a cryptic micromorph from the Upper Cenomanian of Arizona. Geol Mag 125(5):535-539

Kennedy WJ, Cobban WA (1988b) Mid-Turonian ammonite faunas from northern Mexico. Geol Mag 125:593-612

Kennedy WJ, Cobban WA (1990) Cenomanian ammonite faunas from the Woodbine Formation and lower part of the Eagle Ford Group, Texas. Palaeontology 33:75-154

Kennedy WJ, Cobban WA (1991a) Coniacian ammonite faunas from the United States Western Interior. Spec Pap Palaeontol 45:1-96

Kennedy WJ, Cobban WA (1991b) Upper Cretaceous (upper Santonian) Boehmoceras fauna from the Gulf Coast region of the United States. Geol Mag 128(2):167-189

Kennedy WJ, Cobban WA (1993a) Ammonites from the Saratoga Chalk (Upper Cretaceous), Arkansas. J Paleontol 67:404-434

Kennedy WJ, Cobban WA (1993b) Campanian ammonites from the Annona Chalk near Yancy, Arkansas. J Paleontol 67:83-97

Kennedy WJ, Cobban WA (1993c) Maastrichtian ammonites from the Corsicana Formation in northeast Texas. Geol Mag 130(1):57-67

Kennedy WJ, Delamette M (1994) Neophlycticeras Spath, 1922 (Ammonoidea) from the Upper Albian of Ain, France. Neues Jahrb Geol Palaontol Abh 191(1):1-24

Kennedy WJ, Henderson RA (1992) Non-heteromorph ammonites from the Upper Maastrichtian of Pondicherry, South India. Palaeontology 35:381-442

Kennedy WJ, Juignet P (1983) A revision of the ammonite faunas of the type Cenomanian. 1. Introduction, Ancyloceratina. Cretac Res 4:3-83

Kennedy WJ, Juignet P (1984) A revision of the ammonite faunas of the type Cenomanian. 2. The families Binneyitidae, Desmoceratidae, Engonoceratidae, Placenticeratidae, Hoplitidae, Schloenbachiidae, Lyelliceratidae and Forbesiceratidae. Cretac Res 5:93-161

Kennedy WJ, Juignet P (1994) A revision ofthe ammonite faunas of the type Cenomanian, 5. Acanthoceratinae Calycoceras (Calycoceras), C. (Gentoniceras) and C. (Newboldiceras). Cretac Res 15:17-57

Kennedy WJ, Klinger HC (1979) Cretaceous faunas from Zululand and Natal, South Africa. The ammonite superfamily Haplocerataceae Zittel, 1884. Ann S Afr Mus 77(6):85-121

Kennedy WJ, Klinger HC (1985) Cretaceous faunas from Zululand and Natal, South Africa. The ammonite family Kossmaticeratidae Spath. 1922. Ann S Afr Mus 95(5):165-231

Kennedy WJ, Klinger HC (1993) On the affinities of Cobbanoscaphites Collignon, 1969 (Cretaceous Ammonoidea). Ann S Afr Mus 102(7):265-271

Kennedy WJ, Summesberger H (1984) Upper Campanian ammonites from the Gschliefgraben (Ultrahelvetic, Upper Austria). Beitr Paläontol Österr 11:149-206

Kennedy WJ, Summesberger H (1987) Lower Maastrichtian ammonites from Nagoryany (Ukrainian SSR). Beitr Paläontol Österr 13:25-78

Kennedy WJ, Wright CW (1979) Vascoceratid ammonites from the type Turonian. Palaeontology 22:665-683 
Kennedy WJ, Wright CW (1981) Euhystrichoceras and Algericeras, the last mortoniceratine ammonites. Palaeontology 24:417-435

Kennedy WJ, Wright CW (1983) Ammonites polyopsis Dujardin, 1837, and the Cretaceous ammonite family Placenticeratidae Hyatt, 1900. Palaeontology 26:855-873

Kennedy WJ, Wright CW (1984a) The Cretaceous ammonite Ammonites requienianus d'Orbigny, 1841. Palaeontology 27:281-293

Kennedy WJ, Wright CW (1984b) The affinities of the Cretaceous ammonite Neosaynoceras Breistroffer, 1947. Palaeontology 27:159-167

Kennedy WJ, Wright CW (1985a) Evolutionary patterns in Late Cretaceous ammonites. Spec Pap Palaeontol 33:131-143

Kennedy WJ, Wright CW (1985b) Mrhiliceras n.g. (Cretaceous Ammonoidea), a new Cenomanian mantelliceratine. Neues Jahrb Geol Paläontol Mh 9:513-526

Kennedy WJ, Wright CW, Hancock JM (1980) Collignoniceratid ammonites from the mid-Turonian of England and northern France. Palaeontology 23:557-603

Kennedy WJ, Juignet P, Hancock JM (1981a) Upper Cenomanian ammonites from Anjou and the Vendee, western France. Palaeontology 24:25-84

Kennedy WJ, Klinger HC, Summesberger H (1981b) Cretaceous faunas from Zululand and Natal, South Africa. Additional observations on the ammonite subfamily Texanitinae Collignon, 1948. Ann S Afr Mus 86(4):115-155

Kennedy WJ, Wright CW, Klinger HC (1983) Cretaceous faunas from Zululand and Natal, South Africa. The ammonite subfamily Barroisiceratinae Basse, 1947. Ann S Afr Mus 90(6):241-324

Kennedy WJ, Bilotte M, Lepicard B, Segura F (1986) Upper Campanian and Maastrichtian ammonites from the Petites-Pyrenees, southern France. Eclogae Geol Helv 79:1001-1037

Kennedy WJ, Wright CW, Hancock JM (1987) Basal Turonian ammonites from west Texas. Palaeontology 30:27-74

Kennedy WJ, Cobban WA, Hancock JM, Hook SC (1989) Biostratigraphy of the Chispa Summit Formation at its type locality: A Cenomanian through Turonian reference section for transPecos Texas. Bull Geol Inst Univ Upps NS 15:39-119

Kennedy WJ, Hansotte M, Bilotte M, Burnett J (1992) Ammonites and nannofossils from the Campanian of Nalzen (Ariege, France). Geobios 25(2):263-278

Kennedy WJ, Landman NH, Cobban WA, Scott GR (2000) Late Campanian (Cretaceous) heteromorph ammonites from the western interior of the United States. Bull Am Mus Nat Hist 251:1-88

Kennedy WJ, Cobban WA, Klinger HC (2002) Muscle attachment and mantle-related features in Upper Cretaceous Baculites from the United States Western Interior. Abh Geol Bund-Anst 57:89-112

Keupp H (2000) Ammoniten — paläobiologische Erfolgsspiralen. Thorbecke, Stuttgart

Keupp H (2012) Atlas zur Paläopathologie der Cephalopoden. Berl Paläobiol Abh 12:1-390

Keupp H, Riedel F (2010) Remarks on the possible function of the apophyses of the Middle Jurassic microconch ammonite Ebrayiceras sulcatum (Zieten 1830), with a discussion on the palaeobiology of Aptychophora in general. Neues Jahrb Geol Paläontol Abh 255:301-314

Klinger HC (1989) The ammonite subfamily Labeceratinae Spath, 1925. Systematics, phylogeny, dimorphism and distribution (with a description of a new species). Ann S Afr Mus 98(7):189219

Klinger HC, Kennedy WJ (1977) Cretaceous faunas from Zululand, South Africa and southern Mozambique. The Aptian Ancyloceratidae (Ammonoidea). Ann S Afr Mus 73(9):215-359

Klinger HC, Kennedy WJ (1989) Cretaceous faunas from Zululand and Natal. South Africa. The ammonite family Placenticeratidae Hyatt, 1900, with comments on the systematic position of the genus Hypengonoceras Spath, 1924. Ann S Afr Mus 98(9):241-408

Klinger HC, Kennedy WJ (1992) Cretaceous faunas from Zululand and Natal, South Africa. Barremian representatives of the ammonite family Ancyloceratidae Gill, 1871. Ann S Afr Mus 101(5):71-138

Klinger HC, Kennedy WJ (1993) Cretaceous faunas from Zululand and Natal, South Africa. The heteromorph ammonite genus Eubaculites Spath, 1926. Ann S Afr Mus 102(6):185-264

Klug C (2001) Life-cycles of Emsian and Eifelian ammonoids (Devonian). Lethaia 34:215-233 
Klug C (2004) Mature modifications, the black band, the black aperture, the black stripe, and the periostracum in cephalopods from the Upper Muschelkalk, vol (Middle Triassic, Germany). Mitt Geol-Paläont Inst Univ Hamburg 88:63-78

Klug C, Korn D (2003) Morphological pathways in the evolution of Early and Middle Devonian ammonoids. Paleobiology 29:329-348

Klug C, Korn D (2004) The origin of ammonoid locomotion. Acta Palaeontol Pol 49:235-242

Klug C, Korn D, Richter U, Urlichs M (2004) The black layer in cephalopods from the German Muschelkalk (Middle Triassic). Palaeontology 47:1407-1425

Klug C, Brühwiler T, Korn D, Schweigert G, Brayard A, Tilsley J (2007) Ammonoid shell structures of primary organic composition. Palaeontology 50:1463-1478

Klug C, Meyer E, Richter U, Korn D (2008) Soft-tissue imprints in fossil and Recent cephalopod septa and septum formation. Lethaia 41:477-492

Klug C, Riegraf W, Lehmann J (2012) Soft-part preservation in heteromorph ammonites from the Cenomanian-Turonian Boundary Event (OAE 2) in the Teutoburger Wald (Germany). Palaeontology 55:1307-1331

Korn D (1992) Heterochrony in the evolution of Late Devonian ammonoids. Acta Palaeontol Pol 37(1):21-36

Korn D (2012) Quantification of ontogenetic allometry in ammonoids. Evol Dev 14(6):501-514

Korn D, Ebbighausen V (2008) The Early Carboniferous (Mississippian) ammonoids from the Chebket el Hamra (Jerada Basin, Morocco). Foss Rec 11:83-156. doi:10.1002/mmng.200800004

Korn D, Klug C (2002). Ammoneae Devonicae. In: Riegraf W (ed) Fossilium Catalogus 1: Animalia, vol 138.Backhuys, Leiden, pp 1-375

Korn D, Klug C (2003) Morphological pathways in the evolution of early and middle Devonian ammonoids. Paleobiology 29:329-348

Korn D, Klug C (2007) Conch form analysis, variability, and morphological disparity of a Frasnian (Late Devonian) ammonoid assemblage from Coumiac (Montagne Noire, France). In: Landman NH, Davis RA, Manger W, Mapes RH (eds) Cephalopods - present and past. Springer, New York

Korn D, Titus A (2006) The ammonoids from the Three Forks Shale (Late Devonian) of Montana. Foss Rec 9:198-212

Korn D, Klug C, Mapes RH (1999) Viséan and Early Namurian Ammonoids from the Tafilalt (Eastern Anti-Atlas, Morocco). Abh Geol Bundesanst 54:345-375

Korn D, Bockwinkel J, Ebbighausen V (2010) The ammonoids from the Argiles de Teguentour of Oued Temertasset (early Late Tournaisian; Mouydir, Algeria). Foss Rec 13:35-152

Korn D, Mapes RH, Klug C (2014) The coarse wrinkle layer of Palaeozoic ammonoids: new evidence from the Early Carboniferous of Morocco. Palaeontology 57:771-781. doi:10.1111/ pala. 12087

Kraft S, Korn D, Klug C (2008) Ontogenetic patterns of septal spacing in Carboniferous ammonoids. Neues Jahrb Geol Miner Abh 250(1):31-44

Krimholc GJ, Sazonov NT, Kamsyeva-Elpatevskaja VG (1958a) Nadsemejstvo Stephanocerataceae. In: Orlov JA (ed) Osnovy Paleontologii, Molluski-Golovonogie, II. Izdatel'stvo Akademii Nauk SSSR, Moskva, pp 75-79 [in Russian]

Krimholc GJ, Kamsyeva-Elpatevskaja VG, Kachadze IP (1958b) Nadsemejstvo Kosmocerataceae. In: Orlov JA (ed) Osnovy Paleontologii, Molluski-Golovonogie, II. Izdatel'stvo Akademii Nauk SSSR, Moskva, pp 79-82 [in Russian]

Kulicki C (1974) Remarks on the embryogeny and postembryonal development of ammonites. Acta Palaeontol Pol 19:201-224

Kulicki C, Tanabe K, Landman NH, Mapes RH (2001) Dorsal shell wall in ammonoids. Acta Palaeontol Pol 46:23-42

Landman NH (1987) Ontogeny of Upper Cretaceous (Turonian-Santonian) scaphitid ammonites from the Western Interior of North America: Systematics, developmental patterns, and life history. Bull Am Mus Nat Hist 185(2):117-241

Landman NH (1989) Iterative progenesis in Upper Cretaceous ammonites. Paleobiology 15:95117 
Landman NH, Waage KM (1986) Shell abnormalities in scaphitid ammonites. Lethaia 19:211-224

Landman NH, Waage KM (1993) Scaphitid ammonites of the Upper Cretaceous (Maastrichtian) Fox Hills Formation in South Dakota and Wyoming. Bull Am Mus Nat Hist 215:1-257

Landman NH, Dommergues J-L, Marchand D (1991) The complex nature of progenetic speciesexamples from Mesozoic ammonites. Lethaia 24:409-421

Landman NH, Mapes RH, Cruz C (2010) Jaws and soft tissues in ammonoids from the Lower Carboniferous (Upper Mississippian) Bear Gulch Beds, Montana, USA. In: Tanabe K, Shigeta Y, Sasaki T, Hirano H (eds) Cephalopods - present and past. Tokai University Press, Tokyo

Landman NH, Cobban WA, Larson NL (2012) Mode of life and habitat of scaphitid ammonites. Geobios 45:87-98

Leanza H, Zeiss A (1992) On the ammonite fauna of the lithographic limestones from the Zapala region (Neuquén province, Argentina), with the description of a new genus. Zbl Geol Paläontol I 1991(6): 1841-1850

Lehmann U (1966) Dimorphismus bei Ammoniten der Ahrensburger Lias-Geschiebe. Paläontol Z 40(1-2):26-55

Lehmann U (1981) The ammonites: their life and their world. Cambridge University Press, New York

Longbridge LM, Smith PL, Tipper H (2006) The Early Jurassic ammonite Badouxia from British Columbia, Canada. Palaeontology 49:795-816

Luger P, Groschke M (1989) Late Cretaceous ammonites from the Wadi Qena area in the Egyptian Eastern Desert. Palaeontology 32(2):355-407

Macellari CE (1986) Late Campanian-Maaastrichtian ammonite fauna from Seymour Island (Antarctic Peninsula). Paleontol Soc Mem 18:1-55

Machalski M (2005) Late Maastrichtian and earliest Danian scaphitid ammonites from central Europe: Taxonomy, evolution, and extinction. Acta Palaeontol Pol 50:653-696

Maeda H (1991) Sheltered preservation: a peculiar mode of ammonite occurrence in the Cretaceous Yezo Group, Hokkaido, north Japan. Lethaia 24:69-82

Maeda H (1993) Dimorphism of Late Cretaceous false-puzosiine ammonites, Yokoyamaoceras Wright and Matsumoto, 1954 and Neopuzosia Matsumoto, 1954. Trans Proc Palaeontol Soc Jpn NS 169:97-128

Makowski H (1962) Problem of sexual dimorphism in ammonites. Palaeontol Pol 12:1-92

Makowski H (1971) Some remarks on the ontogenetic development and sexual dimorphism in the Ammonoidea. Acta Geol Pol 21:321-340

Makowski H (1991) Dimorphism and evolution of the goniatite Tornoceras in the Famennian of the Holy Cross Mountains. Acta Palaeontol Pol 36:241-254

Mangold C (1970) Morphoceratidae (Ammonitina-Perisphinctoidea) Bathoniens du Jura Méridional, de la Niévre et du Portugal. Geobios 3:43-130

Mangold C (1971) Les Perisphinctidae (Ammonitina) du Jura meridional au Bathonien et au Callovien. Doc Lab Géol Fac Sci Lyon 41:1-246

Mangold K (1987) Reproduction. In: Boyle PR (ed) Cephalopod life cycles. Comparative reviews, vol 2. Academic Press, London, pp 157-200

Mangold-Wirz K (1963) Biologie des Cephalopodes benthiques et nectoniques de la Mer Catalane. Vie Milieu (Suppl) 13:1-285

Mangold-Wirz K, Lu CC, Aldrich EA (1969) A reconsideration of forms of squid of the genus Illex (Illicinae, Ommastrephidae). II. Sexual dimorphism. Can J Zool 47:1153-1156

Mapes RH, Davis RA (1996) Color patterns in ammonoids. In: Landman NH, Tanabe K, Davis RA (eds) Ammonoid paleobiology. Plenum, New York

Mapes RH, Larson NL (2015) Ammonoid Color Patterns. This volume

Mapes RH, Sneck DA (1987) The oldest ammonoid "colour" patterns: description, comparison with Nautilus, and implications. Palaeontology 30:299-309

Marchand D (1976) Quelques précisions sur le polymorphisme dans la famille des Cardioceratidae Douville (Ammonoides). Haliotis 6:119-140

Marcinowski R (1980) Cenomanian ammonites from German Democratic Republic, Poland, and the Soviet Union. Acta Geol Pol 30(3):215-325 
Marcinowski R (1983) Upper Albian and Cenomanian ammonites from some sections of the Mangyshlak and Tuarkyr regions, Transcaspia, Soviet Union. Neues Jahrb Geol Paläontol Mh 3:156-180

Marcinowski R, Wiedmann J (1990) The Albian ammonites of Poland. Palaeontol Pol 50:1-94

Matsumoto T (1987a) Notes on Forbesiceras (Ammonoidea) from Hokkaido (Studies of Cretaceous ammonites from Hokkaido-LX). Trans Proc Palaeontol Soc Jpn NS 145:16-31

Matsumoto T (1987b) Notes on Pachydesmoceras, a Cretaceous ammonite genus. Proc Jpn Acad 63B:5-8

Matsumoto T (1988) A monograph of the Puzosiidae (Ammonoidea) from the Cretaceous of Hokkaido). Palaeont. Soc Jpn Spec Pap 30:1-131

Matsumoto T (1991a) On some acanthoceratid ammonites from the Turonian of Hokkaido (Studies of the Cretaceous ammonites from Hokkaido-LXIX). Trans Proc Palaeontol Soc Jpn NS 164:910-927

Matsumoto T (compiler, 1991b) The mid-Cretaceous ammonites of the family Kossmaticeratidae from Japan. Palaeontol Soc Jpn Spec Pap 33:1-143

Matsumoto T, Saito R (1987) Little known ammonite Crandidiericeras from Hokkaido (Studies of Cretaceous ammonites from Hokkaido-LVIII). Trans Proc Palaeontol Soc Jpn NS 145:1-9

Matsumoto T, Skwarko SK (1991) Ammonites of the Cretaceous Ieru Formation, western Papua New Guinea. BMR J Aust Geol Geophys 12(3):245-262

Matsumoto T, Skwarko SK (1993) Cretaceous ammonites from south-central Papua New Guinea. AGSO J Aust Geol Geophys 14(4):411-433

Matsumoto T, Takahashi T (1992) Ammonites of the genus Acompsoceras and some other acanthoceratid species from the Ikushunbetsu Valley, central Hokkaido. Trans Proc Palaeontol Soc Jpn NS 166:1144-1156

Matsumoto T, Toshimitsu S (1984) On the systematic positions of the two ammonite genera Hourcquia Collignon, 1965 and Pseudobarroisiceras Shimizu, 1932. Mem Fac Sci Kyushu Univ Ser D Geol 25(2):229-246

Matsumoto T, Suekane T, Kawashita Y (1989) Some acanthoceratid ammonites from the Yubari Mountains, Hokkaido-Part 2. Sci Rep Yokosuka City Mus 37:29-44

Matsumoto T, Nemoto M, Suzuki C (1990a) Gigantic ammonites from the Cretaceous Futaba Group of Fukushima Prefecture. Trans Proc Palaeontol Soc Jpn NS 157:366-381

Matsumoto T, Toshimitsu S, Kawashita Y (1990b) On Hauericeras de Grossouvre, 1894, a Cretaceous ammonite genus. Trans Proc Palaeontol Soc Jpn NS 158:439-458

Matsunaga T, Maeda H, Shigeta Y, Hasegawa K, Nomura S-I, Nishimura T, Misaki A, Tanaka (2008) First discovery of Pravitoceras sigmoidale Yabe from the Yezo Supergroup in Hokkaido, Japan. Paleontol Res 12:309-319. doi:10.2517/prpsj.12.309

Matyja BA (1986) Developmental polymorphism in Oxfordian ammonites. Acta Geol Pol 36(13):37-68

Matyja BA (1994) Developmental polymorphism in the Oxfordian ammonite subfamily Peltoceratinae. In: Palaeopelagos Special Publication 1. Proceedings of the 3rd Pergola International Symposium, Rome, pp 277-286

Matyja BA, Wierzbowski A (2001) Palaeogeographical distribution of early Bathonian ammonites of the Asphinctites-Polysphinctites group. Hantkeniana 3:89-103

McCaleb JA (1968) Lower Pennsylvanian ammonoids from the Bloyd Formation of Arkansas and Oklahoma. Geol Soc Am Spec Pap 96:1-123

McCaleb JA, Furnish WM (1964) The Lower Pennsylvanian ammonoid genus Axinolobus in the southern midcontinent. J Paleontol 38(2):249-255

McCaleb JA, Quinn JH, Furnish WM (1964) Girtyoceratidae in the southern midcontinent. Okla Geol Surv Circ 67:1-41

Meek FB, Hayden FV (1856) Descriptions of new fossil species of Mollusca collected by Dr. F. V. Hayden, in Nebraska Territory; together with a complete catalogue of all the remains of Invertebrata hitherto described and identified from the Cretaceous and Tertiary formations of that region. Proc Acad Nat Sci Phila 8:265-286 
Meister C, Alzouma K, Lang J, Mathey B (1992) Les ammonites du Niger (Afrique occidentale) et la transgression transsaharienne au cours du Cénomanien-Turonien. Geobios 25(1):55-100

Melendez G, Fontana B (1993) Intraspecific variability, sexual dimorphism, and non-sexual polymorphism in the ammonite genus Larcheria Tintant (Perisphinctidae) from the middle Oxfordian of western Europe. In: House MR (ed) The ammonoidea: environment, ecology, and evolutionary change (Systematics Association Special), vol 47. Clarendon Press, Oxford

Miller AK (1944) Permian cephalopods. In: King RE, Dunbar CO, Cloud PE Jr, Miller AK (eds) Geology and paleontology of the Permian area northwest of Las Delicias, southwestern Coahuila, Mexico, vol 52. Geological Society of America, Washington, DC, pp 71-127 (Geologial Society of America Special Papers)

Miller AK, Furnish WM (1940) Permian ammonoids of the Guadalupe Mountain region and adjacent areas. Geol Soc Am Spec Pap 26:1-242

Mitta VV (2010) Late Volgian Kachpurites Spath (Craspeditinae, Ammonoidea) of the Russian Platform. Paleontol J 44:622-631

Mojsisovics von Mojsvar E (1893) Das Gebirge um Hallstatt, Theil I, Die Cephalopoden der Hallstätter Kalke. K-K Geol Reichsanst Wien Abh 6(2):1-835

Mojsisovics von Mojsvar JAE (1882) Die Cephalopoden der mediterranen Triasprovinz. Abh K-K Geol Reichsanst Wien Abh 10:1-322

Moltschaniwskyj NA, Martínez P (1998) Effect of temperature and food levels on the growth and condition of juvenile Sepia elliptica (Hoyle, 1885): an experimental approach. J Exp Mar Biol Ecol 229:289-302

Monnet C, Bucher H, Wasmer M, Guex J (2010) Revision of the genus Acrochordiceras Hyatt, 1887 (Ammonoidea, Middle Triassic): Morphology, biometry, biostratigraphy and intraspecific variability. Palaeontology 53:961-996

Moreau P, Francis IH, Kennedy WJ (1983) Cenomanian ammonites from northern Aquitaine. Cretac Res 4:317-339

Morton SG (1834) Synopsis of the organic remains of the Cretaceous groups of the United States. Illustrated by nineteen plates, to which is added an appendix containing a tabular view of the Tertiary fossils discovered in America. Key \& Biddle, Philadelphia, pp. 1-88

Müller AH (1969) Ammoniten mit "Eierbeutel" und die Frage nach dem Sexualdimorphismus der Ceratiten (Cephalopoda). Monatsber Dtsch Akad Wiss Berl 11:411-420

Neige P (1992) Mise en place du dimorphisme (sexuel) chez les Ammonoides. Approche ontogénétique et interprétation hétérochronique. DEA University Bourgogne, pp 1-50

Nettleship MT, Mapes RH (1993) Morphologic variation, maturity, and sexual dimorphism in an Upper Carboniferous ammonoid from the Midcontinent. GSA, Abstracts with Program 25(2):67

Obata I, Futakami M, Kawashita Y, Takahashi T (1978) Apertural features in some Cretaceous ammonites from Hokkaido. Bull Natl Sci Mus (Tokyo) Ser C (Geol) 4(3):139-155

Olivero EB, Medina FA (1989) Dimorfismo en Grossouvrites gemmatus (Huppe) (Ammonoidea) del Cretacico superior de Antartica. Actas Cuarto Congreso Argentino de Paleontología y Bioestratigrafía (Mendoza), pp 65-74

Orbigny A d' (1847) Paléontologie Française. Terraines jurassiques. Part I: Céphalopodes. Masson, Paris

Orbigny A d' (1850) Prodrôme de paléontologie stratigraphique universelle des animaux mollusques \& rayonnés faisant suite au cours élémentaire de paléontologie et de géologie stratigraphiques. Tom, vol 2. Masson, Paris, pp 1-427

Palframan DFB (1966) Variation and ontogeny of some Oxfordian ammonites. Taramelliceras richei (de Loriol) and Creniceras renggeri (Oppel) from Woodham Buckinghamshire. Palaeontology 9:290-311

Palframan DFB (1969) Taxonomy of sexual dimorphism in ammonites: mor-phogenetic evidence in Hecticoceras brightii (Pratt). In: Westermann GEG (ed) Sexual dimorphism in fossil Metazoa and taxonomic implications, vol 1. Stuttgart, Schweizerbart, pp 125-154 (IUGS A)

Parent H (1991) Ammonites Cretácicos de la Formación Rio Mayer (Patagonia austral) Hatchericeras patagonense Stanton (Barremiano) y Sanmartinoceras patagonicum Bonarelli (Albiano). Inst Fisiogr Univ Nac Rosario Notas A 15:1-8 
Parent H (1997) Ontogeny and sexual dimorphism of Eurycephalites gottschei (Tornquist) (Ammonoidea) of the Andean Lower Callovian (Argentine-Chile). Geobios 30:407-419

Parent H (1998) Upper Bathonian and lower Callovian ammonites from Chacay Melehué (Argentina). Acta Palaeontol Pol 43:69-130

Parent H, Scherzinger H, Schweigert G (2008a) Sexual phenomena in Late Jurassic Aspidoceratidae (Ammonoidea). Dimorphic correspondence between Physodoceras hermanni (Berckhemer) and Sutneria subeumela Schneid, and first record of possible hermaphroditism. Palaeodiversity $1: 181-187$

Parent H, Schweigert G, Scherzinger A, Enay R (2008b) Pasottia, a new genus of Tithonian oppeliid ammonites (Late Jurassic, Ammonoidea: Haploceratoidea). Bol Inst Fisiogr Geol 78:23-30

Parent H, Greco AF, Bejas M (2009) Size-Shape Relationships in the Mesozoic planispiral ammonites. Acta Palaeontol Pol 55:85-98

Parent H, Garrido AC, Schweigert G, Scherzinger A (2011) The Tithonian ammontie fauna and stratigraphy of Picún Leufú, southern Neuquén Basin, Argentina. Rev Paléobiol 30:45-104

Parent H, Garrido AC, Schweigert G, Scherzinger A (2013). Andean Lower Tithonian (Picunleufuense Zone) ammonites and aptychus from Estancia Maria Juana, southern Neuquén Basin, Argentina. Boletín del Instituto de Fisiografía y Geología 83:27-34

Pavia G, Zunino M (2012) Ammonite assemblages and biostratigraphy at the Lower to Upper Bajocian boundary in the Digne area (SE France). Implications for the definition of the Lower Bajocian GSSP. Rev Paléobiol Vol Spéc 11:205-227

Pelseneer $\mathrm{P}$ (1926) La proportion relative des sexes chez les animaux et particulièrement chez les Mollusques. Acad R Belg Cl Sci (Mem 2ieme Ser) 8(11):1-258

Ploch I (2003) Taxonomic interpretation and sexual dimorphism in the Early Cretaceous (Valanginian) ammonite Valanginites nucleus (Roemer, 1841). Acta Geol Pol 53:201-208

Ploch I (2007) Intraspecific variability and problematic dimorphism in the Early Cretaceous (Valanginian) ammonite Saynoceras verrucosum (d'Orbigny, 1841). Acta Geol Sin 81:877-882

Quenstedt FA (1885) Die Ammoniten des Schwäbischen Jura. Schweizerbart, Stuttgart

Raup DM, Crick RE (1981) Evolution of single characters in the Jurassic ammonite Kosmoceras. Paleobiology 7:200-215

Raup DM, Michelson A (1965) Theoretical morphology of the coiled shell. Science 147:1294 1295

Reboulet S (1995) L'évolution des ammonites du Valanginien-Hauterivien inférieur du Bassin Vocontien et de la Plate-forme Provencale (Sud-Est de la France). Doc Lab Géol Lyon 137:1-371

Rein S (2001) Neue Erkenntnisse zur Evolutionsbiologie der germanischen Ceratiten - Ontogenese, Phylogenese und Dimorphismusverhalten. Freib Forsch C 492:99-120

Rein S (2003) Zur Biologie der Ceratiten der spinosus-Zone - Ergebnisse einer Populationsanalyse, Teil I: Populationsstatistik, Sexual-Dimorphismus und Artkonzept. Veröff Naturkundemus Erf 22:29-50

Reyment RA (1971) Vermuteter Dimorphismus bei der Ammonitengattung Benueites. Bull Geol Inst Univ Uppsl NS 3(1):1-18

Reyment RA (1982) Size and shape variation in some Japanese upper Turonian (Cretaceous) ammonites. Stock Contrib Geol 37(16):201-214

Reyment RA (1988) Does sexual dimorphism occur in Upper Cretaceous ammonites? Senckenb leth 69(1/2):109-119

Riccardi AC, Aguirre Urreta MB, Medina FA (1987) Aconeceratidae (Ammonitina) from the Hauterivian-Albian of southern Patagonia. Palaeontogr A 196:105-185

Richter U (2002) Gewebeansatz-Strukturen auf pyritisierten Steinkernen von Ammonoideen. Geol Beitr Hann 4:1-113

Roper CFE, Sweeney MJ (1975) The pelagic octopod Ocythoe tuberculata Rafinesque, 1814. Bull Am Malacol Union 1975:21-28

Ruzhencev VE (1962) Superorder Ammonoidea. The ammonoids - general part. In: Ruzhencev VE (ed) Molluscs Cephalopods. I. Publishing House of the Academy of Science of the USSR, Moscow [in Russian] 
Ruzhencev VE (1974) Superorder Ammonoidea. General section. In: Orlov YA, Ruzhencev VE (ed) Fundamentals of paleontology. V. Mollusca: Cephalopoda I. Jerusalem

Sandoval J, Chandler RB (2000) The sonniniid ammonite Euhoploceras from the Middle Jurassic of South-West England and southern Spain. Palaeontology 43:495-532

Saunders WB, Spinosa C (1978) Sexual dimosphism in Nautilus from Palau. Paleobiology 4:349358

Saunders WB, Ward PD (1987) Ecology, distribution and population characteristics of Nautilus. In: Saunders WB, Landman NH (eds) Nautilus. The biology and paleobiology of a living fossil. Plenum Press, New York

Scherzinger A., Mitta V. (2006) New data on ammonites and stratigraphy of the Upper Kimmeridgian and Lower Volgian (Upper Jurassic) of the middle Volga Region (Russia). Neues Jahrb Geol Paläontol Abh 241:225-251

Schiappa TA, Spinosa C, Snyder WS (1995) Nevadoceras, a new Early Permian adrianitid (Ammonoidea) from Nevada. J Paleontol 69:1073-1079

Schindewolf OH (1937) Zur Stratigraphie und Paläontologie der Wocklumer Schichten (Oberdevon). Abh Preuß Geol Landesanst, NF 178:1-132

Schweigert G (1997) Die Ammonitengattungen Simocosmoceras Spath und Pseudhimalayites Spath (Aspidoceratidae) im süddeutschen Oberjura. Stuttg Beitr Naturk B 246:1-29

Schweigert G (1998) Die Ammonitenfauna des Nusplinger Plattenkalks (Ober-Kimmeridgium, Beckeri-Zone, Ulmense-Subzone, Württemberg). Stuttg Beitr Naturk B 267:1-61

Schweigert G, Dietze V (1998) Revision der dimorphen Ammonitengattungen Phlycticeras Hyatt-Oecoptychius Neumayr (Strigoceratidae, Mitteljura). Stuttg Beitr Naturk B 269:1-59

Schweigert G, Dietl G, Dietze V (2003) Neue Nachweise von Phlycticeras und Oecoptychius (Ammonitina: Strigoceratidae: Phlycticeratinae). Stuttg Beitr Naturk B 335:1-21

Schweigert G, Dietze V, Chandler RB, Mitta V (2007) Revision of the Middle Jurassic dimorphic ammonite genera Strigoceras/Cadomoceras (Strigoceratidae) and related forms. Stuttg Beitr Naturk B 373:1-74

Seilacher A (1974) Fabricational noise in adaptive morphology. Syst Biol 22:451-465

Seilacher A, Gunji YP (1993) Morphogenetic countdown: another view on heteromorph shells in gastropods and ammonites. Neues Jahrb Geol Paläontol Abh 190:237-265

Senior JR (1971) Wrinkle-layer structures in Jurassic ammonites. Palaeontology 14:107-113

Shea BT (1986) Ontogenetic approaches to sexual dimorphism in anthropods. Hum Evol 1(2):97110

Siebold CT (1848) Lehrbuch der vergleichenden Anatomie, vol 1. Veit, Berlin

Stephenson LW (1941) The larger invertebrates of the Navarro Group of Texas (exclusive of corals and crustaceans and exclusive of the fauna of the Escondido Formation). (University of Texas) Bulletin 4101:1-641

Sturani C (1966) Ammonites and stratigraphy of the Bathonian in the Digne- Barreme area (southeastern France, Dept. Basses- Alpes). Boll Soc Paleontol Ital 5:3-57

Sun YC (1928) Mundsaum und Wohnkammer der Ceratiten des Oberen deutschen Muschelkalks. Weg, Leipzig

Tafur R, Villegas P, Rabí M, Yamashiro C (2001) Dynamics of maturation, seasonality of reproduction and spawning grounds of the jumbo squid Dosidiscus gigas (Cephalopoda: Ommastrephidae) in Peruvian waters. Fish Res 54:33-50

Tajika A, Naglik C, Morimoto N, Pascual-Cebrian E, Hennhöfer DK, Klug C (2014) Empirical 3D-model of the conch of the Middle Jurassic ammonite microconch Normannites, its buoyancy, the physical effects of its mature modifications and speculations on their function. Historical Biology, 11 pp. doi: 10.1080/08912963.2013.872097

Tanabe K (1977) Functional evolution of Otoscaphites puerculus (Jimbo) and Scaphites planus (Yabe), Upper Cretaceous ammonites. Mem Fac Sci Kyushu Univ Ser D Geol 23(3):367-407

Tanabe K, Landman NH, Mapes RH (1998) Muscle attachment scars in a Carboniferous goniatite. Paleontol Res 2(2):130-136

Thierry J (1978) Le genre Macrocephalites au Callovien inférieur (Ammonites, Jurassique moyen). Mém Géol Univ Dijon 4:1-490 
Thierry J, Charpy N (1982) Le genre Tornquistes (Ammonitina, Pachyceratidae) a l'Oxfordien inférieur et moyen en Europe occidentale. Geobios 15:619-677

Till A (1909) Die fossilen Cephalopodengebisse. K-K Geol Reichsanst Jahrb 58(4):573-608

Till A (1910) Die fossilen Cephalopodengebisse. Folge 3. K-K Geol Reichsanst Jahrb 59:407-426

Tintant H (1963) Les Kosmoceratides du Callovien inférieur et moyen d'Europe occidentale. University of Dijon, France

Tintant H (1976) Le polymorphisme intraspécifique en paléontologie. Exemple pris chez les ammonites. Haliotis 6:49-69

Tornquist A (1898) Der Dogger am Espinazito Pass. Paläontol Abh NF 3(2):3(135)-69(201)

Tozer KT (1994) Canadian Triassic ammonoid faunas. Geol Surv Can Bull 467:1-663

Trewin NH (1970) A dimorphic goniatite from the Namurian of Cheshire. Palaeontology 13:40-46

Trueman AE (1941) The ammnonite body chamber, with special reference to the buoyancy and mode of life of the living ammonite. Q J Geol Soc Lond 96:339-383

Urdy S, Goudemand N, Bucher H, Chirat R (2010a) Allometries and the morphogenesis of the molluscan shell: a quantitative and theoretical model. J Exp Zool B 314:280-302

Urdy S, Goudemand N, Bucher H, Chirat R (2010b) Growth dependent phenotypic variation of molluscan shell shape: implications for allometric data interpretation. J Exp Zool B 314:303326

Urlichs M (2009) Weiteres über Dimorphismus bei Ceratites (Ammonoidea) aus dem Germanischen Oberen Muschelkalk (Mitteltrias) mit Revision einiger Arten. Neues Jahrb Geol Paläontol Abh 251:199-223

Vermeij GJ (1993) A natural history of shells. Princeton University Press, Princeton

Walliser OH (1963) Dimorphismus bei Goniatiten. Paläontol Z 37(1-2):21

Walliser OH (1970) Über die Runzelschicht bei Ammonoidea. Gött Arb Geol Paläontol 5:115-126

Walton SA, Korn D, Klug C (2010) Size distribution of the late devonian ammonoid Prolobites: indication for possible mass spawning events. Swiss J Geosci 103:475-494

Ward PD (1987) The natural history of Nautilus. Allen and Unwin, Boston

Weitschat W, Bandel K (1991) Organic components in phragmocones of boreal Triassic ammonoids; implications for ammonoid biology. Paläontol Z 65:269-303

Wells MJ (1962) Brain and behavior in cephalopods. Stanford University Press, Stanford

Wells MJ (1966) The brain and behavior of cephalopods In: Wilbur KM, Younge CM (eds) Physiology of mollusca. Academic Press, New York

Wenger R (1957) Die Germanischen Ceratiten. Paleontogr A 108:57-129

Westermann GEG (1964a) Sexual-Dimorphismus bei Ammonoideen und seine Bedeutung für Taxionomie der Otoitidae (einschliesslich Sphaeroceratinae; Ammonitina, M. Jura). Palaeontogr A 124(1-3):33-73

Westermann GEG (1964b) The ammonite fauna of the Kialagvik formation at Wide Bay, Alaska Peninsula. Part I. Lower Bajocian (Aalenian). Bull Am Palaeontol 47:327-503

Westermann GEG (1969a) Supplement: sexual dimorphism, migration, and segregation in living cephalopods. In: Westermann GEG (ed) Sexual dimorphism in fossil Metazoa and taxonomic implications (IUGS, Series A1). Schweizerbart, Stuttgart

Westermann GEG (1969b) Proposal: classification and nomenclature of dimorphs at the genusgroup level [with discussion]. In: Westermann GEG (ed) Sexual dimorphism in fossil Metazoa and taxonomic implications (IUGS, Series A1). Schweizerbart, Stuttgart

Westermann GEG (1971) Form, structure, and function of shell and siphuncle in coiled Mesozoic ammonoids. Life Sci Contrib R Ont Mus 78:1-3

Westermann GEG, Riccardi AC (1979) Middle Jurassic ammonoid fauna and biochronology of the Argentine-Chilean Andes. Part II: Bajocian Stephanocerataceae. Palaeontogr A 164:85-188

Wiedmann J (1965) Origins, limits, and systematic position of Scaphites. Palaeontology 8:397453

Wiedmann J (1973) The Albian and Cenomanian Tetragonitiae (Cretaceous Ammonoidea), with special reference to the Circum-Indic species. Eclogae Geol Helv 66:585-616

Willey A (1895) In the home of the Nautilus. Nat Sci Lond 6(40):405-414 
Willey A (1902) Contribution to the natural history of the pearly nautilus. In: Zoological results based on material from New Britain, New Guinea, Loyalty Islands, and Elsewhere, collected during the years 1895, 1896, and 1897. Cambridge University Press, Cambridge

Wilmsen M, Mosavinia A (2011) Phenotypic plasticity and taxonomy of Schloenbachia varians (J. Sowerby, 1817) (Cretaceous Ammonoidea). Paläontol Z 85:169-184

Wright CW, Kennedy WJ (1980) Origin, evolution and systematics of the dwarf acanthoceratid Protacanthoceras Spath, 1923 (Cretaceous Ammonoidea). Bull Br Mus (Nat Hist) Geol 34(2):65-107

Wright CW, Kennedy WJ (1984) The Ammonoidea of the Lower Chalk. Part I. (Monograph Palaeontographical Society London 567, part of vol 137 for 1983). Palaeontographical Society, London, pp 1-126

Wright CW, Kennedy WJ (1987) The Ammonoidea of the Lower Chalk. Part 2. (Monograph Palaeontographical Society London 573, part of vol 139 for 1985). Palaeontographical Society, London, pp 127-218

Wright CW, Kennedy WJ (1990) The Ammonoidea of the Lower Chalk. Part 3. (Monograph Palaeontographical Society London 585, part of vol 144 for 1990). Palaeontographical Society, London, pp 219-294

Wright CW, Kennedy WJ (1994) Evolutionary relationships among Stoliczkaiinae (Cretaceous ammonites) with an account of some species from the English Stoliczkaia dispar Zone. Cretac Res 15:547-582

Wright CW, Callomon JH, Howarth MK (1996) Cretaceous Ammonoidea. In: Kaesler RL (ed) Treatise on invertebrate paleontology, Part L, Mollusca 4 (revised). GSA and University of Kansas Press, Lawrence

Wright JK (2010) The Aulacostephanidae (Ammonoidea) of the Oxfordian/Kimmeridgian boundary beds (Upper Jurassic) of Southern England. Palaeontology 53:11-52

Zaborski PMP (1987) Lower Turonian (Cretaceous) ammonites from south-east Nigeria. Bull Br Mus (Nat Hist) Geol 41(2):31-66

Zakharov YD (1969) Problems of sexual dimorphism in fossil cephalopods, an impotant subject in modern systematics. In Gramm N, Krassilov VA (eds) Problems of phylogeny and systematics. Acad Sci USSR, Far Eastern Geological Institute, All Union Paleontology Society of Vladivostok [in Russian]

Zakharov YD (1977) Ontogeny of ceratites of the genus Pinacoceras and developmental features of the suborder Pinacoceratina. Paleontol J 4:445-451

Zatoń M (2008) Taxonomy and palaeobiology of the Bathonian (Middle Jurassic) tulitid ammonite Morrisiceras. Geobios 41:699-717

Zatoń M (2010) Bajocian-Bathonian (Middle Jurassic) ammonites from the Polish Jura. Part 2: families Stephanoceratidae, Perisphinctidae, Parkinsoniidae, Morphoceratidae and Tulitidae. Palaeontogr A 292:115-213

Zeiss A (1969) Dimorphismus bei Ammoniten des Unter-Tithon. Mit einigen allgemeinen Bemerkungen zum Dimorphismus-Problem. In: Westermann GEG (ed) Sexual dimorphism in fossil Metazoa and taxonomic implications. International Union Geological Science, A1. Schweizerbart, Stuttgart

Zhao J, Zheng Z-G (1977) The Permian ammonoids from Zhejiang and Jiangxi. Acta Palaeontol Sin 16(2):217-254

Zhou Z (1985) Several problems on the Early Permian ammonoids from south China. Palaeontol. Cathayana 2:179-210

Ziegler B (1974) Über Dimorphismus und Verwandtschaftsbeziehungen bei ‘Oppelien’ des oberen Juras (Ammonoidea: Haplocerataceae). Stuttg Beitr Naturk B 11:1-42

Ziegler B (1987) Der weiße Jura der Schwäbischen Alb. Stuttg Beitr Naturk C 23:1-71 